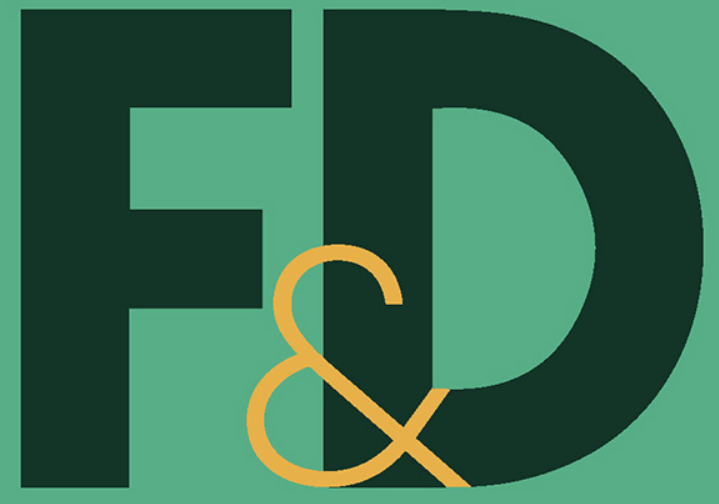

\title{
DECEMBER 2019
}

Carbon calculus P.6

FINANCE AND DEVELOPMENT

The Economics of Climate

Fifty shades

of green P.12

The adaptive age P.20 


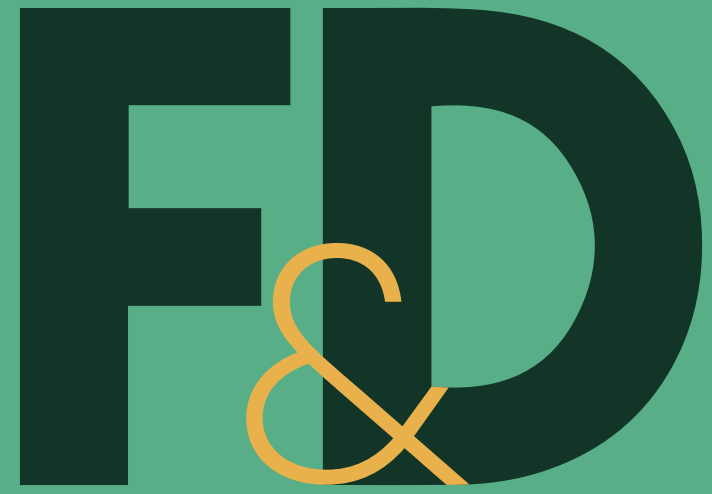

\section{DECEMBER 2019}

\section{Carbon calculus P.6}

FINANCE AND DEVELOPMENT

The Economics of Climate

Fifty shades of green P.12

The adaptive age P.20 


\section{Contents}

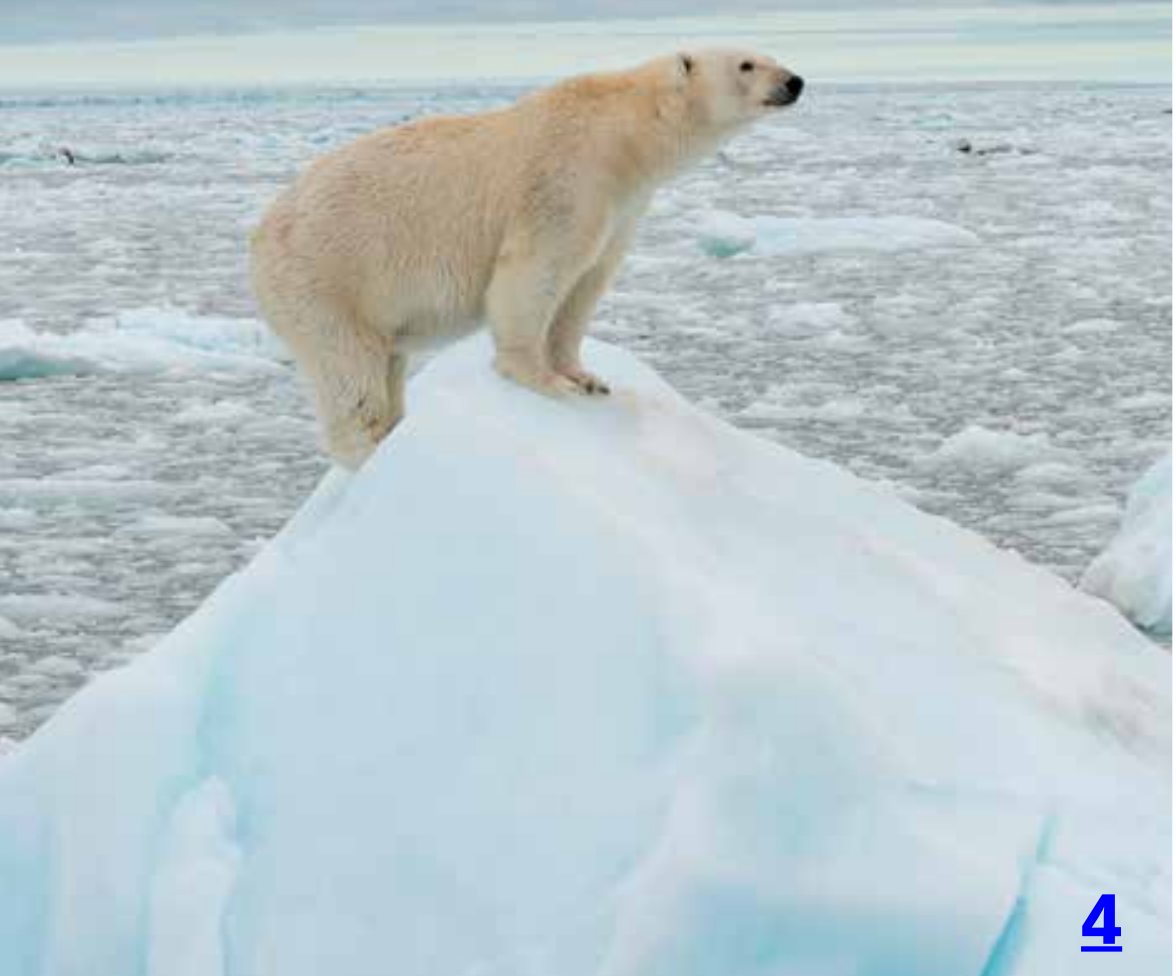

We should treat the natural world as we would the economic world and protect our natural capital.

\section{THE ECONOMICS OF CLIMATE}

\section{$4 \quad$ The Greatest Balancing Act}

Nature and the global economy

David Attenborough and Christine Lagarde

6 Carbon Calculus

For deep greenhouse gas emission reductions, a long-term perspective on costs is essential Kenneth Gillingham

\section{Fifty Shades of Green}

The world needs a new, sustainable financial system to stop runaway climate change Mark Carney

\section{Putting a Price on Pollution}

Carbon-pricing strategies could hold the key to meeting the world's climate stabilization goals Ian Parry

\section{Investing in Resilience}

Disaster-prone countries are strengthening their ability to withstand climate events Bob Simison

\section{Climate Change and Financial Risk}

Central banks and financial regulators are starting to factor in climate change

Pierpaolo Grippa, Jochen Schmittmann, and Felix Suntheim

\section{Reaping What We Sow}

Smart changes to how we farm and eat can have a huge impact on our planet Nicoletta Batini

\section{Nature's Solution to Climate Change}

A strategy to protect whales can limit greenhouse gases and global warming

Ralph Chami, Thomas Cosimano, Connel Fullenkamp, and Sena Oztosun 


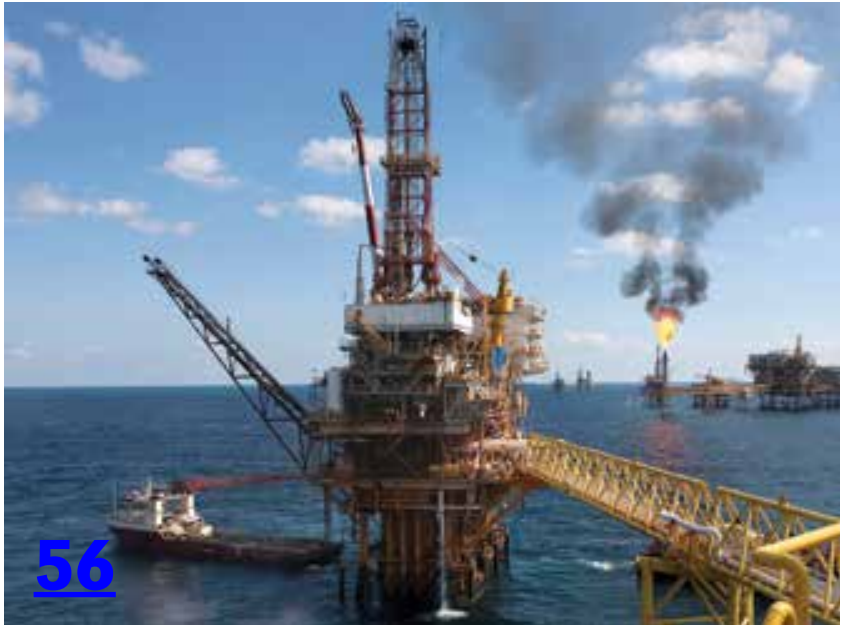

ALSO IN THIS ISSUE

\section{Tackling Inequality}

How can we address inequality in the 21st century? Start with climate change

Lyndsay Walsh

\section{Grass Roots}

From Brazil to New Zealand, local activists show that small-scale initiatives can make a difference

Daphne Ewing-Chow, Anna Jaquiery, Denise Marin, Ashlin Mathew, and David Smith

\section{Hidden Giants}

It's time for more transparency in the management and governance of national oil companies

David Manley, David Mihalyi, and

Patrick R. P. Heller

\section{A Greener Future for Finance}

The successes and challenges of green bonds offer lessons for sustainable finance

Afsaneh Beschloss

and Mina Mashayekhi

\section{The SDR's Time Has Come}

Rethinking the Special Drawing

Right could bolster the IMF's

role in the global financial safety net

José Antonio Ocampo

\section{DEPARTMENTS}

\section{Straight Talk}

\section{The Adaptive Age}

No institution or individual can stand on the sidelines in the fight against climate change

Kristalina Georgieva

\section{People in Economics}

\section{City Slicker}

Chris Wellisz profiles Harvard's Edward Glaeser, who sees urbanization as a path to prosperity

\section{In the Trenches}

\section{Going against the Tide}

Brazil's Ilan Goldfajn explains why central bankers ought to follow their convictions

\section{Currency Notes}

\section{Ahead of His Time}

Mathematician and computer science pioneer Alan Turing will appear on UK currency

Melinda Weir

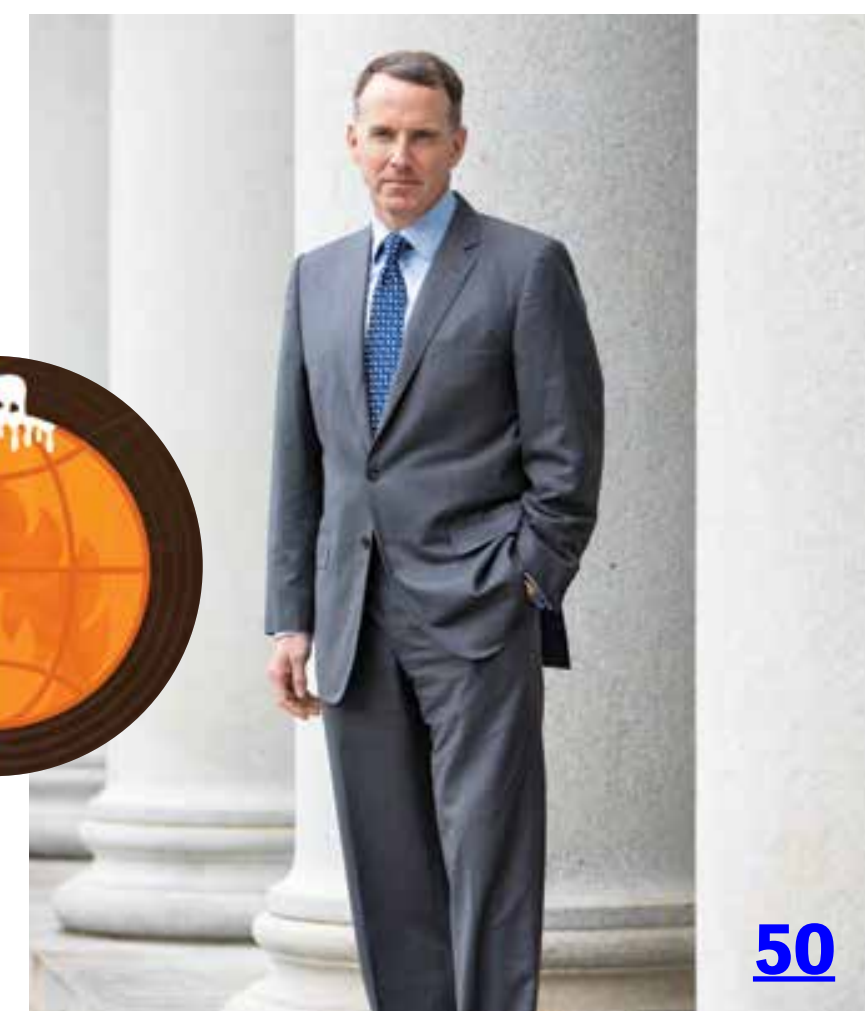




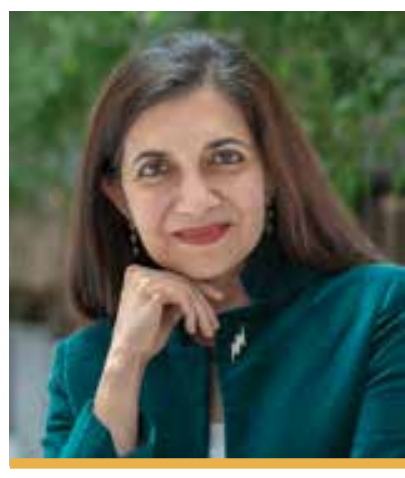

\section{A New Climate Economy}

"EVERYBODY TALKS ABOUT the weather, but nobody does anything about it." The quip, attributed to 19th-century American humorist Mark Twain, might describe the current state of play on climate change. In Twain's day, it was absurd to suppose humans could do anything about the weather.

Today, we understand that we can and we must.

The changing climate, largely wrought by humans, is bringing rising sea levels, temperature extremes, and more frequent and harsher storms. These threaten to displace lives, livelihoods, and communities, with clear economic consequences, often at a high price tag, around the world.

Simply put, climate is the biggest risk the world faces. What can we do to move from talk to action?

This issue of Finance $\sigma^{2}$ Development looks at the economic and financial impact of climate policy choices. It points to concrete solutions that offer growth opportunities, driven by technological innovation, sustainable investment, and a dynamic private sector.

For IMF Managing Director Kristalina Georgieva, dealing with climate change requires not only mitigating damage, but also adapting for the future. This means pricing risk and providing incentives for green investment. Kenneth Gillingham shows that in the long run, the costs of climate action may be lower than we think. Ian Parry estimates that aggressive carbon taxes would help individual nations meet their emission-reduction goals and scale up action globally. Mark Carney and others show how harnessing finance can open enormous opportunities-from transforming energy to reinventing protein.

In this shared crisis, everyone has a responsibility to act. Ultimately, the world's fortunes and those of future generations depend on the ambition and urgency with which leaders collaborate to address the global climate emergency today.

But there is hope. Today's young people, like Greta Thunberg and others, serve as reminders of just how capable human beings can be of remaking the world. It is their future at stake. FD

GITA BHATT, editor-in-chief

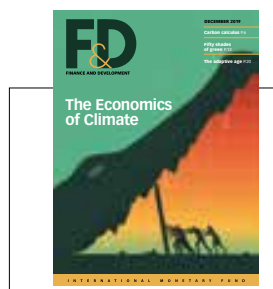

\section{ON THE COVER}

Time is running out to save our planet, and everyone has a responsibility to act. Illustrator Davide Bonazzi's December's 2019 cover likens the threat of climate change to the closing jaws of a crocodile, shown in silhouette against a steadily warming earth.
EDITOR-IN-CHIEF:

Gita Bhatt

MANAGING EDITOR:

Maureen Burke

SENIOR EDITOR:

Chris Wellisz

EDITOR:

Glenn Gottselig

DIGITAL EDITOR:

Rahim Kanani

ONLINE EDITOR:

Lijun Li

PRODUCTION MANAGER:

Melinda Weir

COPY EDITORS:

Michael Harrup

Lucy Morales

ADVISORS TO THE EDITOR:

Bernardin Akitoby

Thomas Helbling

Celine Allard

Tommaso Mancini Griffoli

Bas Bakker

Steven Barnett

Nicoletta Batini

Helge Berger

Paul Cashin

Luis Cubeddu

Alfredo Cuevas

Rupa Duttagupta

Gian Maria Milesi-Ferretti

Christian Mumssen

Inci Ötker

Catriona Purfield

Uma Ramakrishnan

Abdelhak Senhadji

Alison Stuart

C 2019 by the International Monetary Fund. All rights reserved. For permission to reproduce any $F \& D$ content, submit a request via online form (www.imf.org/external/terms.htm) or by e-mail to copyright@imforg. Permission for commercial purposes also available from the Copyright Clearance Center (www.copyright.com) for a nominal fee.

Opinions expressed in articles and other materials are those of the authors; they do not necessarily reflect IMF policy.

Subscriber services, changes of address, and advertising inquiries:

IMF Publication Services

Finance \& Development

PO Box 92780

Washington, DC 20090, USA

Telephone: (202) 623-7430

Fax: (202) 623-7201

E-mail: publications@imf.org

Postmaster: send changes of address to Finance \& Development International Monetary Fund, PO Box 92780, Washington, DC 20090, USA.

The English edition is printed at Dartmouth Printing Company, Hanover, NH.

Finance \& Development is published quarterly by the International Monetary Fund, 700 19th Street NW, Washington, DC 20431, in English, Arabic, Chinese, French, Russian, and Spanish. English edition ISSN 0145-1707

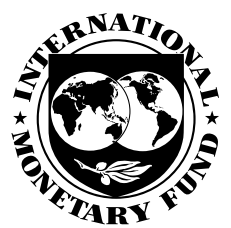

FSC FPO 


\section{Forthcoming from the IMF}

\section{Debt and}

\section{Entanglements}

Between

the Wars

"Modern, industrialized warfare is

extraordinarily expensive-so expensive that its prosecution requires a state to take on tremendous public debt. The question facing a state, whether it wins or loses the war, is how it can survive politically under the constraint of the debt. The carefully researched essays in this fascinating book not only show how the belligerents in World War l experimented with a combination of strategies - tax increases, financial repression, inflation, debt rescheduling, selective default, and inter-governmental

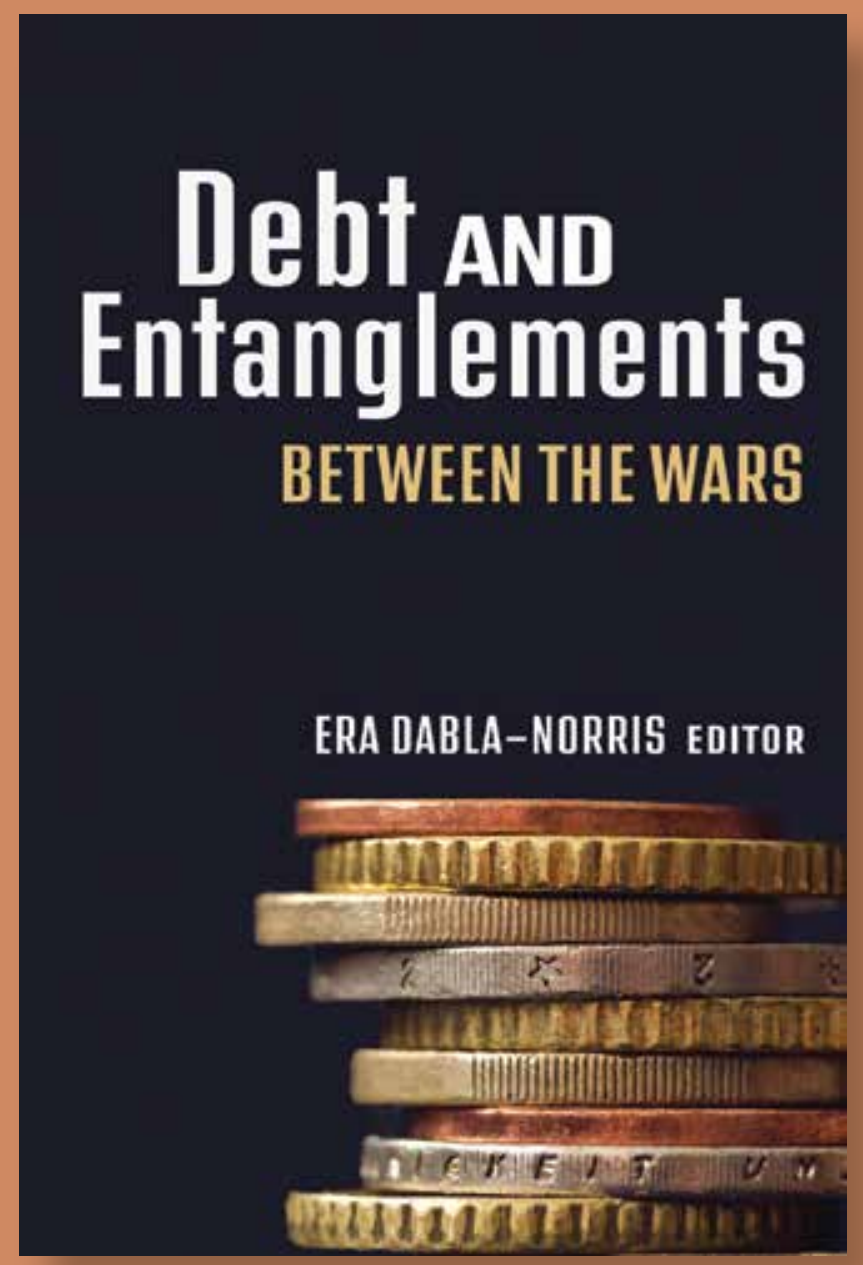
guarantees - to address this political optimization problem, they also show the long-run economic r.imfe.li/28327 costs of those strategies. The analyses not only teach us about history but have implications for the present day."

\section{—Stephen Haber, Stanford University}




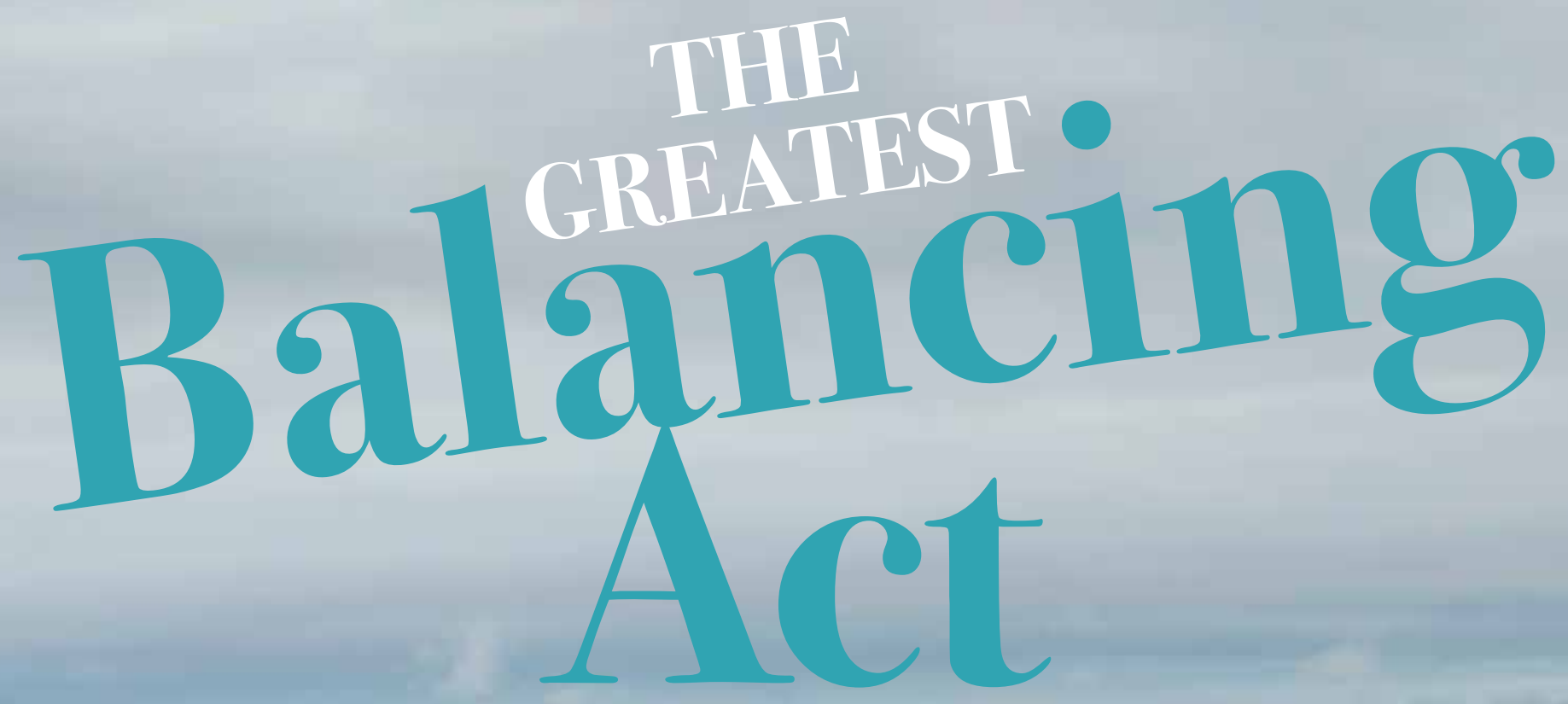

\section{Nature and the Global Economy \\ Based on a conversation between David Attenborough and Christine Lagarde}


厂 n nature, everything is connected. This is equally true of a healthy environment and a healthy economy. We cannot hope to sustain life without taking care of nature. And we need healthy economies to lift people out of poverty and achieve the United Nations Sustainable Development Goals.

In our current model these goals sometimes seem to collide, and our economic pursuits encroach too closely on nature. But nature-a stable climate, reliable freshwater, forests, and other natural resources-is what makes industry possible. It is not one or the other. We cannot have long-term human development without a steady climate and a healthy natural world.

\section{Out of touch}

The bottom line is that when we damage the natural world, we damage ourselves. The impact of our growing economic footprint threatens our own future directly. By some estimates, more than 50 percent of the world's population is now urbanized, increasing the likelihood of people losing touch with nature.

With the projected rise in ocean levels and increase in the average temperature of the planet, large swaths of land, even whole countries, will become uninhabitable, triggering mass climateinduced migration. Never has it been more important to understand how the natural world works and what we must do to preserve it.

A necessary first step is to recognize that waste is the enemy. Wasting food, energy, or materials flies in the face of sustainability. Producing plastics fated to end up as litter is a waste, especially when these plastics pollute our oceans. If we could live by the simple injunction to "do no harm," both individually and as businesses and economies, we could all make a difference. Overconsumption and unsustainable production have put the planet in peril.

\section{Natural connection}

Since the natural and economic worlds are linked, similar principles apply to both.

In the financial world, for example, we would not eat into capital to the point of depletion because that would bring about financial ruin. Yet in the natural world, we have done this repeatedly with fish stocks and forests, among many other resources - in some cases to the point of decimation. We must treat the natural world as we would the economic world - protecting natural capital so that it can continue to provide benefits well into the future.

This is something economists can appreciatethe importance of minimizing waste, taking advantage of efficiencies, and accurately reflecting costs in prices, including costs imposed on our entire shared resource, the environment.

We can take the important step of ensuring that the price of fossil fuel energy reflects not only production costs but also environmental costs-a price tag on carbon and other greenhouse gases. We must eliminate energy subsidies that encourage a continued search for new fossil fuels or that promote overuse and waste-harming both natural and human health. IMF research has found that the implicit global subsidy from undercharging for energy and its environmental costs in 2017 was a staggering $\$ 5.2$ trillion, or 6.5 percent of world GDP.

\section{Change begins now}

When it comes to sustaining the vital symbiosis between the economic and the natural world, we all can do more-much more. The private sector can stop supporting or subsidizing industries and activities that damage the planet and instead invest in sustainable development. Governments can roll out policies to fight climate change and the destruction of nature, for example, through promotion of clean-technology research and development.

Change must begin now, and it must encompass us all. The youth of today understand thisthink about courageous young people like Greta Thunberg and others like her. They are calling on older generations to act now to reverse climate change-because it is their futures at stake. Because of these younger generations, there is hope.

Nature is resilient. We can still reverse some of the damage we have inflicted on our precious planet. But time is running out. If we don't take decisive action in the next 10 to 20 years, the damage will have passed irreversible tipping points.

We must work in concert and on several fronts, and we must do it now.

For who among us wants to face harsh reproach from our grandchildren: "you knew it was happening, and you did nothing." FD

This essay is based on a conversation between SIR DAVID

ATTENBOROUGH, natural historian and narrator of the Netflix/WWF documentary series Our Planet, and former IMF managing director CHRISTINE LAGARDE. 


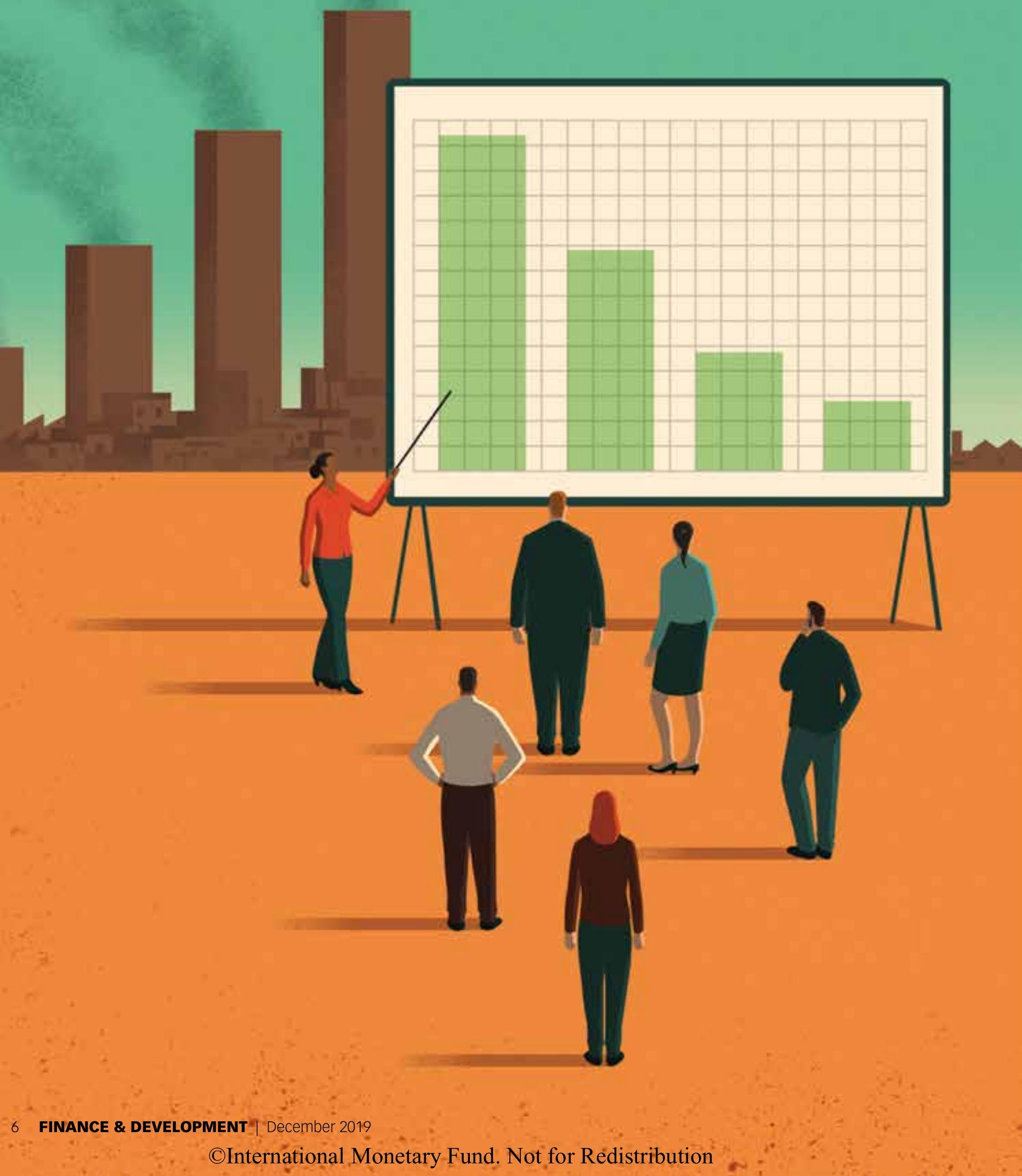




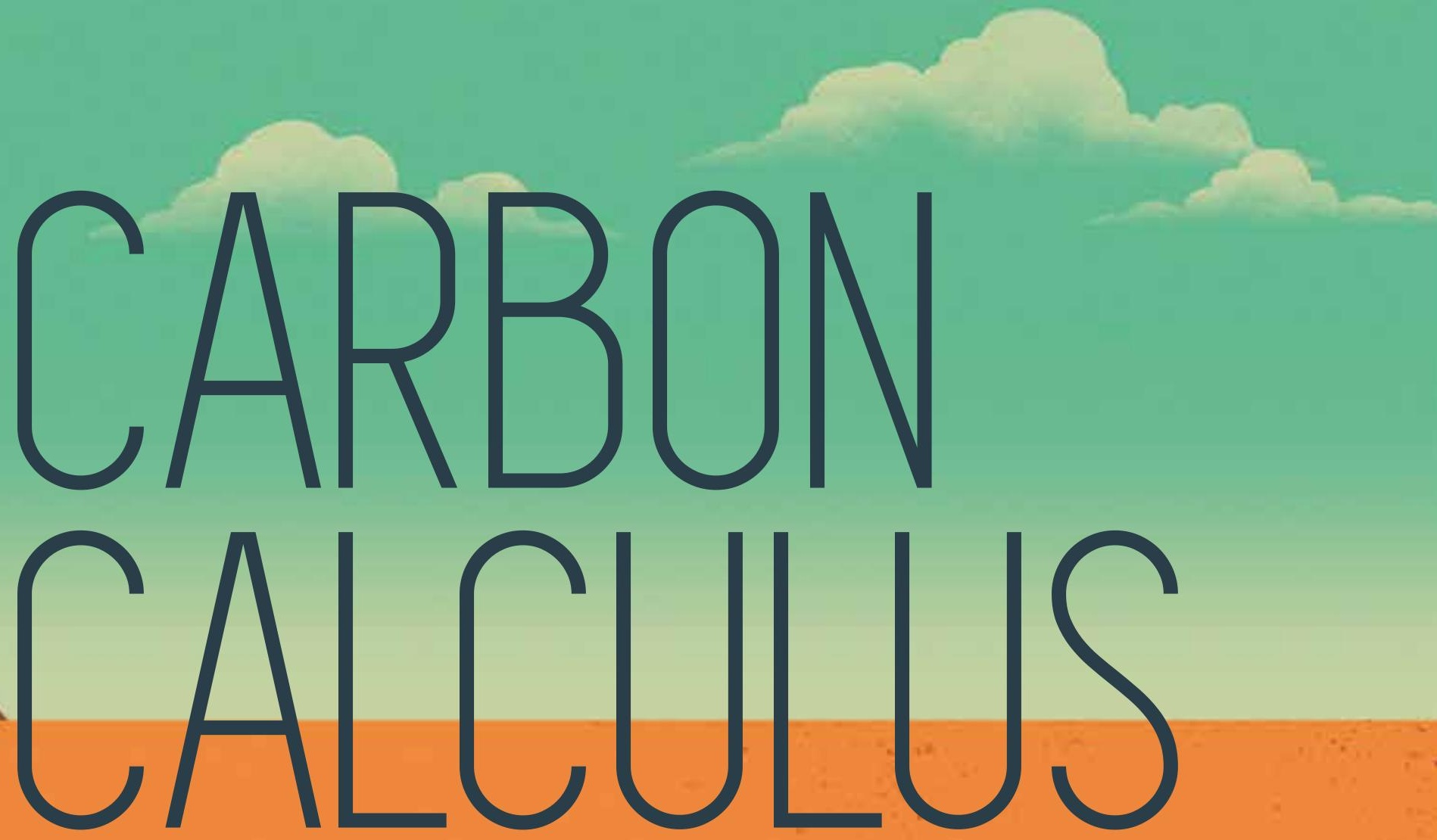

\section{For deep greenhouse gas emission reductions, a long-term perspective on costs is essential}

\section{Kenneth Gillingham}

he scientific consensus is clear: climate change is associated with increasingly frequent and intense natural disasters ranging from droughts and wildfires to hurricanes and coastal flooding. While the extent of the economic damage cannot be known for certain, strong evidence suggests it could be quite severe. The challenge for policymakers will be to decide how much to spend on measures to reduce greenhouse gas emissions. To do that, they must be able to compare the costs of various options, including renewable-energy sources and electric cars.

The challenge is taking on increasing urgency in the policy world as climate scientists argue that emission reductions must be rapid and deep, with a goal of reaching net zero by 2050, if not sooner (Millar and others 2017). That goal, which many countries have already embraced, will require a vast transformation of the energy sources used to power the global economy, and it would mean going far beyond 


\section{Some activities that appear expensive in the short term may actually turn out to be low-cost approaches in the long term, because of induced innovation.}

business-as-usual technological progress. Indeed, the US Energy Information Administration's International Energy Outlook 2019 projects that fossil fuels will still generate 57 percent of electricity in 2050.

How much would it cost to move beyond business as usual and come within striking distance of net-zero emissions by 2050? To answer this question, it's important to distinguish between short- and long-term costs. In the short term, there are some inexpensive ways to reduce emissions, but deeper cuts run up against quickly rising costs. However, some activities - especially those involving fledgling low-carbon technologies- that appear expensive in the short term may actually turn out to be low-cost approaches in the long term, because of induced innovation. This insight suggests that

Chart 1

\section{Comparing costs}

Renewable-energy technologies are among the least costly relative to existing coal generation.

(Dollars per ton of carbon dioxide, in 2017 dollars)

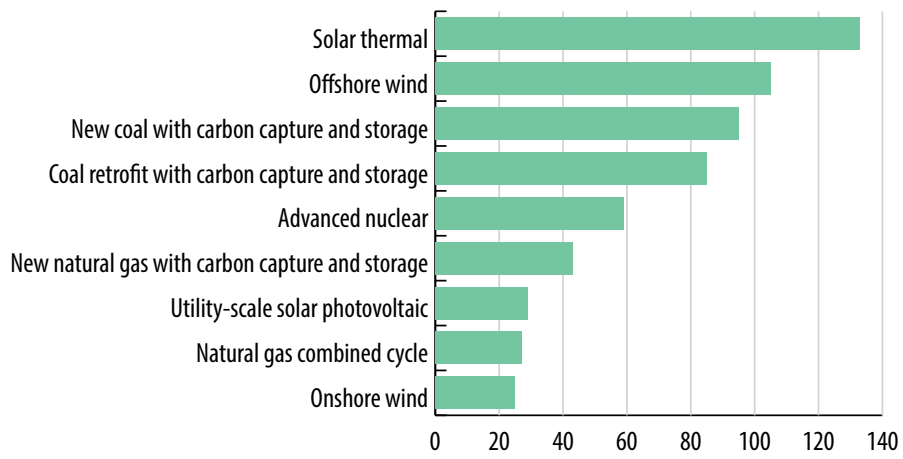

Source: Kenneth Gillingham and James H. Stock, "The Cost of Reducing Greenhouse Gas Emissions," Journal of Economic Perspectives 32, no. 4 (Fall 2018): 53-72.

Note: Estimates are derived from the US Energy Information Administration's Annual Energy Outlook 2018. Costs are projected for facilities that come online in 2022. Costs do not include federal renewable-energy tax credits or other subsidies. the longer-term cost of mitigation may be lower than is widely assumed.

\section{Short-term costs of technologies}

To calculate the short-term costs of mitigating greenhouse gas emissions, economists estimate the up-front costs and divide by the number of tons of carbon dioxide (or equivalent) emissions reduced. For example, suppose a government spends $\$ 20$ million to promote the development of wind farms to generate electricity, reducing carbon dioxide emissions by 1 million tons. The short-term cost of the mitigation would be $\$ 20$ per ton. This method provides a useful way of comparing the costs of various ways of reducing emissions.

Of course, one must be cautious in interpreting results focused on an individual technology or policy in isolation. For instance, there could be interactions among policies, and the costs associated with technologies may vary by location and exactly how the technology is implemented. And estimates of such costs are changing every year. Indeed, the cost of solar and wind generation has declined rapidly over the past decade, and the decline appears likely to continue.

My colleague James Stock and I estimated the unsubsidized costs of various technologies to reduce greenhouse gas emissions based on a review of recent economic literature and the Energy Information Administration's Annual Energy Outlook 2018 (Chart 1). The costs are expressed in relation to existing coal generation, which is a useful benchmark because coal is the most carbon-intensive fuel. In many countries, policymakers will have to decide whether to close existing coal plants on the path toward decarbonization. These estimates are averages from the United States, and one should be cautious in applying them elsewhere.

The most striking takeaway is that renewableenergy technologies are among the least costly. (This result $c a n$ be applied outside the United 
States, because markets for most renewable technologies are global.) In fact, the cost of wind and solar may be even lower when implicit or explicit subsidies are included. However, these estimates do not account for the intermittency of renewable energy generation-after all, the sun does not shine and wind does not blow all the time (Joskow 2019). At high levels of use, renewables must be complemented with storage technologies such as pumped hydroelectric storage or batteries, or with a form of generation that can quickly fill the gap when the supply of wind or solar power falters.

In the United States, a low-cost, low-carbon alternative to coal is a power plant that incorporates both gas and steam turbines to increase efficiency. Known as natural gas combined-cycle generation, this solution takes advantage of the copious supply of inexpensive fracked shale gas. One caveat: the estimated cost of $\$ 27$ per ton assumes that no methane leaks from wells, pipelines, or storage facilities. Methane is a potent greenhouse gas, and the gigantic leak at Aliso Canyon, California, in 2015 shows that natural-gas generation may produce higher greenhouse gas emissions-and thus higher costs per ton of all greenhouse gases reduced.

\section{Social cost}

To understand how sensible it is to spend money on these emissions reductions, we can compare them to estimates of carbon's social cost, which quantifies the incremental damage resulting from emitting a ton of carbon dioxide and other greenhouse gases into the atmosphere. This incremental damage includes factors such as losses (or gains in northern climates) to agriculture caused by global warming, flooding from sea level rise, and destruction from more-severe tropical cyclones and additional wildfires. The administration of US President Barack Obama developed a central-case estimate of $\$ 50$ per ton of carbon dioxide in 2019.

Several technologies for mitigation turn out to be less expensive than carbon when this estimate of carbon's social cost is used (suggesting they are no-brainers), while others are more expensive, such as solar thermal and offshore wind. Benchmarks other than the $\$ 50$ per ton estimate may also be useful. For instance, a recent IMF report estimates that a tax of $\$ 75$ per ton of carbon dioxide applied around the world would make it possible to meet the Paris Agreement target of limiting global warming to $2^{\circ} \mathrm{C}$ over preindustrial
Table 1

\section{Wide range}

Economic studies show that costs of short-term measures to reduce carbon dioxide emissions vary widely.

\begin{tabular}{|c|c|}
\hline POLICY MEASURE & $\begin{array}{l}\text { ESTIMATED COST OF } \\
\text { REDUCING CARBON } \\
\text { DIOXIDE EMISSIONS } \\
\text { (2017 DOLLARS PER TON) }\end{array}$ \\
\hline Behavioral energy efficiency & -190 \\
\hline Corn starch ethanol & $-18-+310$ \\
\hline Reforestation & $1-10$ \\
\hline Renewable-portfolio standards & 0-190 \\
\hline $\begin{array}{l}\text { Corporate Average Fuel Economy } \\
\text { (CAFE) standards }\end{array}$ & $-110-+310$ \\
\hline Wind energy subsidies & $2-260$ \\
\hline Clean power plants & 11 \\
\hline Gasoline taxes & $18-47$ \\
\hline Methane-flaring regulations & 20 \\
\hline Reducing federal coal leasing & $33-68$ \\
\hline Agricultural emission policies & $50-65$ \\
\hline National clean energy standards & $51-110$ \\
\hline Soil management & 57 \\
\hline Livestock management policies & 71 \\
\hline Concentrating solar power expansion & 100 \\
\hline Renewable fuel subsidies & 100 \\
\hline Low-carbon fuel standards & $100-2,900$ \\
\hline Solar photovoltaic system subsidies & $140-2,100$ \\
\hline Biodiesel & $150-420$ \\
\hline Energy efficiency programs & $250-300$ \\
\hline Cash for clunkers & $270-420$ \\
\hline Weatherization assistance programs & 350 \\
\hline $\begin{array}{l}\text { Dedicated-battery electric- } \\
\text { vehicle subsidies }\end{array}$ & $350-640$ \\
\hline
\end{tabular}

Source: Kenneth Gillingham and James H. Stock, "The Cost of Reducing Greenhouse Gas Emissions," Journal of Economic Perspectives 32, no. 4 (Fall 2018): 53-72.

Note: The policies in the table are from around the world, but most are from the United States. Costs for greenhouse gases other than carbon dioxide are converted to carbon dioxide equivalents based on the gases' global warming potential. Estimates are based either on individual studies or on a range of estimates from different studies. 
levels. If this $\$ 75$ estimate is used instead of $\$ 50$, advanced nuclear becomes another option that is less expensive than carbon's social cost.

\section{Short-term costs of policies}

So far, we have looked at the costs today of unsubsidized technologies, which is useful for understanding the direction markets will be going in the near future. It is clear that as old generation plants are retired and new ones are built, there will be a shift toward renewable-energy technologies, regardless of policy. However, this switch may be much slower than would otherwise be dictated by the ambitious goals many governments have set. So it is also important to understand the costs of emission reductions resulting from different policy measures governments could undertake.

A look at studies in the economics literature reveals an extremely wide range of costs for policies that have been implemented and evaluated (Table 1). At the low end are energy efficiency interventions, which actually save money. In behavioral economics, these are often referred to as "nudges," because they simply involve providing or reframing information to influence, or nudge, energy-consumption-related decisions toward a more environmentally friendly approach. A well-known example are reports included in electricity bills that compare a household's electricity use with that of its neighbors. Such interventions are inexpensive and can reduce electricity use by about 2 percent, yielding net savings. While these measures may pay for themselves, the resulting emission reductions tend to be modest and have a relatively small role in deeper decarbonization efforts.

At the high-cost end are many policies that appear to be quite expensive when looking at short-run, static costs. Most notable are policies to induce additional renewable generation and to help decarbonize transportation. In fact, the most expensive are subsidies for electric vehicles. This is because in many places, such vehicles are charged using electricity from fossil fuel sources, which reduces potential emission savings.

Yet such technologies may ultimately be cheaper than the table's short-term estimates suggest. That's because many may provide side benefits such as reduced air pollution, which could make them attractive even if they entail high carbon emissionreduction costs. Moreover, in the longer term, their resulting emission reductions and cost per ton reduced may look very different, owing to spillovers from induced technological change.

\section{Long-term, dynamic costs}

Why do innovation spillovers make a difference? Climate change is a long-term, intergenerational problem, with carbon dioxide in the atmosphere persisting for hundreds to thousands of years. Thus, technological change and innovation are central to longer-term efforts to mitigate climate change by developing alternatives to fossil fuels. While technologies to steeply reduce emissions are available today, there is not only tremendous inertia in the energy system, but also much room for further cost declines in the technology. These considerations lend themselves to a long-term, dynamic perspective that accounts for how spending on new technologies today may lower the cost of reducing emissions in the future.

There are several reasons why taking the longer-run, dynamic perspective makes sense. Economists know that research and development generates spillovers because firms often can only partly appropriate the gains it brings. For example, once a patent expires, any firm can take advantage of the associated innovation. There may also be cases where engineering and managerial improvements from producing a new technology lower the technology's costs (often called "learning by doing"), and some of the cost reductions may spill over to other firms. For instance, there is evidence that firms in the semiconductor industry lowered their production costs as they produced more of each generation of semiconductors and that these lowered costs spilled over to other firms (Irwin and Klenow 1994). There may also be positive network effects, with benefits to society from the adoption of a single standard, such as one plug that works for charging all electric vehicles. All three types of spillovers allow other firms to reduce costs, improving social welfare and providing an economic motivation for carefully designed policies to foster such spillovers.

Apart from spillovers, recent work in the economics of clean-energy innovation has emphasized that optimal policy may be quite different in the long term simply because expenditures today may have long-term effects. Some of the approaches to reducing emissions that are more expensive in the short term may spur innovation that could lead to lower long-term costs than existing approaches. Consider 


\section{Technological change and innovation are central to longer-term efforts to mitigate climate change by developing alternatives to fossil fuels.}

subsidies for electric vehicles, which include rapidly improving technology such as batteries. If policy today for clean technology can reduce costs substantially in the future, then it may make sense to undertake more expensive options today (Acemoglu and others 2016; Vogt-Schilb and others 2018). In principle, this finding holds even if only a single firm adopts the low-carbon innovation (so there would be no innovation spillovers), although in practice there will almost certainly be spillovers leading to lower long-term costs. The key insight is that when society chooses how best to address climate change, the optimal long-term decision may differ from the short-term, myopic decision. Of course, it is not easy to foresee how technology will unfold, so any decision involves uncertainty. But we know that mature technologies are less likely to see major leaps than nascent ones. Thus, the long-term view applies only to newer low-carbon technologies with real potential to reduce costs in the future.

\section{Game changers}

Let's return to our original question. Is it possible to decarbonize deeply enough to come within striking distance of net-zero greenhouse gas emissions by 2050? Yes, it is feasible even today-the technologies exist. Yet such a vast transformation of the energy system will be costly and challenging if attempted all at once, especially considering the large short-term costs of the transition for fossil-fuel-reliant developing nations. There are certainly inexpensive measures that can be implemented today, including energy conservation, efficiency nudges, and the replacement of retiring fossil-fuel powered electricity generation with renewables. The costs of these measures are already lower than the damage from climate change they would avert, based on estimates of carbon's social cost. But many other approaches are quite costly in the short term, especially efforts to promote new low-carbon technologies. However, when the policies have strong potential to spur innovation, they may lead to much lower total costs over the longer term.

A long-term perspective that keeps innovation in mind is crucial in considering ways to tackle climate change. Innovations such as small modular nuclear reactors and carbon capture technologies could be game changers in achieving net-zero greenhouse gas emissions at a low cost. Granted, as the Danish physicist Niels Bohr said, "prediction is very difficult, especially if it is about the future." The future path of technology is unknown, so we can at best speculate about the ultimate cost of reaching net zero. Yet we can plan for the future without regret by providing incentives for both low-cost greenhouse gas mitigation and low-carbon innovation, such as economy-wide carbon pricing, while also judiciously investing in new technologies.

KENNETH GILLINGHAM is an associate professor of environmental and energy economics at Yale University. This article is adapted from a 2018 article he wrote with James H. Stock, "The Cost of Reducing Greenhouse Gas Emissions," published in the Journal of Economic Perspectives.

\section{References}

Acemoglu, Daron, Ufuk Akcigit, Douglas Hanley, and William Kerr. 2016. "Transition to Clean Technology." Journal of Political Economy 124, no. 1:52-104. https://www. journals.uchicago.edu/doi/abs/10.1086/684511

Irwin, Douglas, and Peter Klenow. 1994. "Learning-by-Doing Spillovers in the Semiconductor Industry." Journal of Political Economy 102, no. 6: 1200-27. https://doi. org/10.1086/261968

Joskow, Paul L. 2019. "Challenges for Wholesale Electricity Markets with Intermittent Renewable Generation at Scale: The US Experience." Oxford Review of Economic Policy 35, no. 2: 291-331. https://doi.org/10.1093/oxrep/grz001

Millar, Richard J., Jan S. Fuglestvedt, Pierre Friedlingstein, and others. 2017. "Emission Budgets and Pathways Consistent with Limiting Warming to $1.5^{\circ} \mathrm{C}$." Nature Geoscience 10: 741-47. https://www.nature.com/articles/ngeo3031

Vogt-Schilb, Adrian, Guy Meunier, and Stephane Hallegatte. 2018. "When Starting With the Most Expensive Option Makes Sense: Optimal Timing, Cost and Sectoral Allocation of Abatement Investment." Journal of Environmental Economics and Management 88: 210-33. https://doi.org/10.1016/j.jeem.2017.12.001 


\section{Fifty Shades of Green}

\section{The world needs a new, sustainable financial system to stop runaway climate change}

\section{Mark Carney}

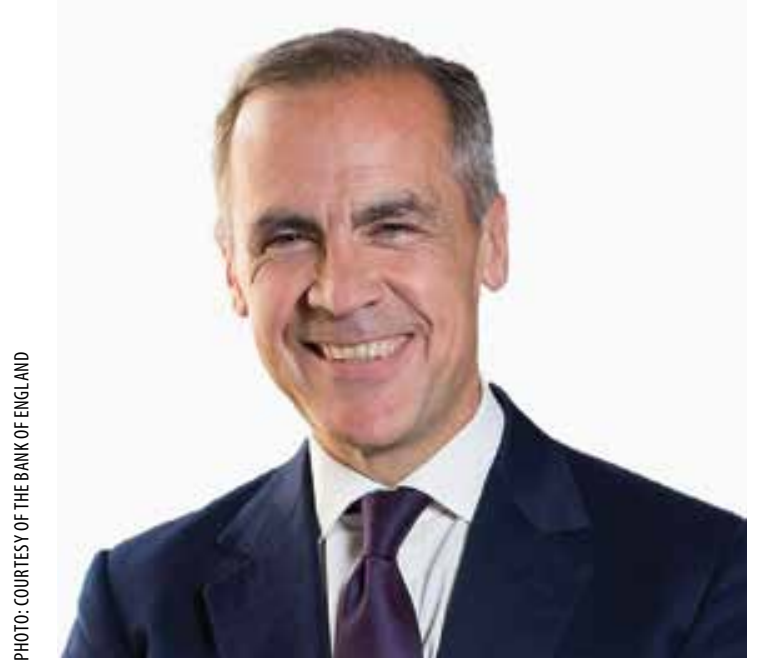

THIS YEAR the threats from climate change spurred demonstrations across the world and prompted the parliaments in the United Kingdom and many other countries to declare a "climate emergency." These actions occurred against a backdrop of record temperatures across Europe and North America, the worst wildfires ever in the Amazon basin, severe tropical storms in Asia, and sea levels that are rising faster than previously thought.

The human costs are immeasurable.

The financial losses, however, can be measured, and they are significant. Insured losses in 2018 were $\$ 80$ billion, double the inflation-adjusted average for the past 30 years.

But protection gaps in low- and middle-income countries mean that even greater costs are being borne by the uninsured. In 2017, a record $\$ 140$ billion in insured losses was eclipsed by an additional uninsured $\$ 200$ billion. In some of the countries most exposed to climate change-Bangladesh, Egypt, India, Indonesia, Nigeria, the Philippines, and Vietnam-insurance penetration is less than 1 percent.

The potential economic benefits of closing the insurance gap are striking. Lloyd's of London estimates that a 1 percent rise in insurance penetration can translate into a 13 percent reduction in uninsured losses and a 20 percent lower disaster recovery burden on taxpayers. Substantial macroeconomic benefits include increased investment, higher output (potentially up to 2 percent of GDP), and greater climate resilience.

A 2018 Intergovernmental Panel on Climate Change report stresses that we have only 12 years left to stop runaway climate change. That is two average business cycles, $12 \mathrm{IMF}$ annual meetings, 48 meetings of the Bank of England's Financial Policy Committee. But currently the world is moving in the wrong direction: global energy emissions increased 1.7 percent last year. To limit warming to $1.5^{\circ} \mathrm{C}$ requires a 45 percent decrease by 2030 and net-zero emissions by 2050 .

The changes needed to keep warming below $1.5^{\circ} \mathrm{C}$ are enormous: massive reallocation of capital is needed, which presents unprecedented risks and opportunities. The International Energy Agency estimates that a low-carbon transition could require $\$ 3.5$ trillion in energy sector investment every year for decades - twice the current rate. Under the agency's scenario, in order for carbon to stabilize by 2050 , nearly 95 percent of the electricity supply must be low carbon and 70 percent of new cars electric, and the carbon dioxide intensity of the building sector must fall 80 percent.

For markets to anticipate and smooth the transition to a net-zero world, they need the right information; proper risk management; and coherent, credible public policy frameworks.

Here's how.

\section{A new finance}

A new, sustainable financial system is under construction. It is funding the initiatives and innovations of the private sector and amplifying the effectiveness of governments' climate policies - it could even accelerate the transition to a low-carbon economy.

Unfortunately, like virtually everything about the response to climate change, this new sustainable financial system is not developing fast enough for the world to reach net zero. 
This is the Tragedy of the Horizon. The catastrophic effects of climate change will be felt well beyond the traditional horizons of most actorsimposing a cost on future generations that the current generation has little direct incentive to fix.

To bring climate risks and resilience into the heart of financial decision making, climate disclosure must be comprehensive, climate risk management must be transformed, and sustainable investing must go mainstream.

\section{Reporting}

Catalyzed by the G20 and established by the private sector, the Task Force on Climate-related Financial Disclosures (TCFD) is a comprehensive, practical, and flexible framework for corporate disclosure of climate-related risks and opportunities.

Since the TCFD set out its recommendations for climate-related disclosure, there has been a jump in both the demand and supply of climate reporting.

The demand for TCFD disclosure is now enormous. Current supporters control balance sheets totaling \$120 trillion and include the world's top banks, asset managers, pension funds, insurers, creditrating agencies, accounting firms, and shareholder advisory services. As a result, companies are much more highly motivated to disclose and manage climate-related risks. Moreover, climate change claimed its first Standard \& Poor's 500 bankruptcy last year, and climate-related shareholder resolutions spiked to 90 . Investment managers controlling more than 45 percent of global assets under management now back shareholder actions on carbon disclosure, and companies representing over 90 percent of all shareholder advisory services now support the TCFD.

And disclosure is on the rise: four-fifths of the top 1,100 G20 companies now disclose climate-related financial risks as some TCFD recommendations advise. Three-quarters of those who use this information have seen an improvement in the quality of climate disclosure.

The next step is to make disclosure mandatory, as the United Kingdom and European Union have already signaled.

It's time for every country to get involved because the world won't get to net zero if the financial sector doesn't know how our companies are responding. In order to watch, we must be able to see.

Over the next two years, the current process of disclosure by the users of capital, reaction by the suppliers of capital, and adjustment of these standards will be critical to ensure that the TCFD standards are as comparable, as efficient, and as decisionrelevant as possible.

\section{Risk management}

The providers of capital — banks, insurers, and asset managers and those who supervise them-must all achieve better understanding and management of climate-related financial risks.

Changes in climate policies, new technologies, and growing physical risks will prompt reassessment of the value of virtually every financial asset. Firms that align their business models with the transition to a net-zero world will reap handsome rewards. Those that fail to adapt will cease to exist. The longer meaningful adjustment is delayed, the greater the disruption will be.

\section{Changes in climate policies, new technologies, and growing physical risks will prompt reassessment of the value of virtually every financial asset.}

As the supervisor of the world's fourth-largest insurance industry, the Bank of England knows that general insurers and reinsurers are on the front line of management of the physical risks from climate change. Insurers have responded by developing their modeling and forecasting capabilities, improving exposure management, and adapting coverage and pricing.

The Bank of England's latest survey finds that almost three-quarters of banks are starting to treat the risks from climate change like other financial risks - rather than viewing them simply as a corporate social responsibility. Banks have begun to consider the most immediate physical risks to their business models - from the exposure of mortgage books to flood risk to the impact of extreme weather events on sovereign risk. And they are taking steps to assess exposure to transition risks in anticipation of climate action. This includes exposure to carbon-intensive sectors, consumer loans for diesel vehicles, and mortgages for rental properties, given new energy efficiency requirements.

The Bank of England is overhauling its supervisory approach in anticipation of this major shift, setting out our expectations with respect to the following: 


\section{Financial markets increasingly recognize sustainable investment as a new horizon that opens up enormous opportunities ranging from transforming energy to reinventing protein.}

- Governance: Firms will be expected to embed the consideration of climate risks fully into governance frameworks, including at the board level, and assign responsibility for oversight of these risks to specific senior managers.

- Risk management: Firms must consider climate change in accordance with their board-approved risk appetite.

- Regular use of scenario analysis: This is necessary to test strategic resilience.

- Appropriate disclosure of climate risks: Firms must develop and maintain methods to evaluate and disclose these risks.

The Bank of England will be the first regulator to stress-test its financial system under various climate pathways, including the catastrophic business-asusual scenario and the ideal—but still challenging - transition to net zero by 2050 consistent with the UK-legislated objective.

This stress test will bring cutting-edge risk management techniques into the mainstream, and it will make the heart of the global financial system more responsive to changes to both the climate and to government climate policies.

This test will be the first of its kind to integrate climate scenarios with macroeconomic and financial models. The Bank of England will develop the approach in consultation with industry, such as insurers and other informed stakeholders, including experts from the Network of Central Banks and Supervisors for Greening the Financial System-a 48-member group representing jurisdictions that account for half of global emissions.

\section{New horizon}

Financial markets increasingly recognize sustainable investment as a new horizon that opens up enormous opportunities ranging from transforming energy to reinventing protein.

With an estimated $\$ 90$ trillion in infrastructure investment expected between 2015 and 2030, smart decisions today can ensure investment that is both financially rewarding and environmentally sustainable.
The green bond market offers investors stable, rated, and liquid investments with long duration. For issuers, green bonds are a way to tap the huge $\$ 100$ trillion pool of long-term private capital managed by global institutional fixedincome investors. The shift to capital markets from banks will also free up limited bank balance sheet capacity for early-stage project financing and infrastructure lending.

However, while they are important catalysts, specialist investments like green bonds will not be sufficient to finance the transition to a low-carbon future. They accounted for only 3 percent of global bond issuance in 2018 .

For sustainable investment to go truly mainstream, it needs to do more than exclude incorrigibly brown industries and finance new, deep-green technologies. Sustainable investing must catalyze and support all companies that are working to shift from brown to green.

Such "tilt" investment strategies, which overweight high environmental, social, and governance (ESG) stocks, and "momentum" investment strategies, which focus on companies that have improved their ESG ratings, have outperformed global benchmarks for close to a decade.

The mainstreaming of such strategies and the tools to pursue them are essential. At present, one of the biggest hurdles to doing so is the inconsistent measurement of ESG. We need a common taxonomy to help financial markets rigorously identify environmental outperformance and direct investment accordingly. The EU green taxonomy and green bond standard are a good start, but they are binary (dark green or brown only).

Eventually asset owners should be able to report the climate pathway of their portfolios.

Mainstreaming sustainable investment calls for a richer taxonomy -50 shades of green.

\section{Avoiding a 'Minsky moment'}

A financial market in the transition to a $1.5^{\circ} \mathrm{C}$ world is under construction, revealing the likely future cost of business and payment for emissions, but we need to move much faster. 
Now it's time for a giant step to bring the reporting, risk management, and return optimization of sustainable finance into everyday financial decision making.

Ultimately, the speed with which the new sustainable financial system develops will be decided by the ambitions of government climate policies.

If more countries turn their Paris commitments into legislated objectives and concrete actions, the financial system will amplify the impact of their efforts by advancing sustainable investments and shutting down unsustainable activity.

Financial policymakers will not drive the transition to a low-carbon economy, but they do have a clear interest in ensuring that the financial system can adapt to changes hastened by those decisions and avoid a climate "Minsky moment."

Our role is to develop the frameworks for markets to adjust efficiently. The right frameworks will allow feedback between the market and policymaking, so that climate policy is a bit more like monetary policy-policymakers will learn from markets' reactions, and markets will internalize policymakers' objectives, strategies, and instruments.

But the speed with which this market develops will be heavily influenced by the coherence and credibility of climate policies. Finance will complement-and potentially amplify-but never substitute for climate policy action. The policy frameworks with the greatest impact will be time-consistent (not arbitrarily changed); transparent (with clear targets, pricing, and costing); and committed (through treaties, nationally determined contributions, domestic legislation, and consensus).

When countries build their track records and their credibility grows, the market will allocate capital to deliver the necessary innovation and growth and hasten the adjustment to a low-carbon future. The more prolific the reporting, the more robust the risk assessment, and the more widespread the return optimization, the quicker the transition, breaking the Tragedy of the Horizon. FD

MARK CARNEY is governor of the Bank of England.

ALL IMF PUBLICATIONS I $\mathbf{N}$ A $\mathbf{N}$ I $N$ T E G R A T E D ENVIRONMENT S UP P ORTED BY USER-FRIENDLY NAVIGATION, INTUITIVE SEARCH, AND PERSONALIZATION FEATURES. AT NO CHARGE? 


\section{PUTTING A PRICE ON}
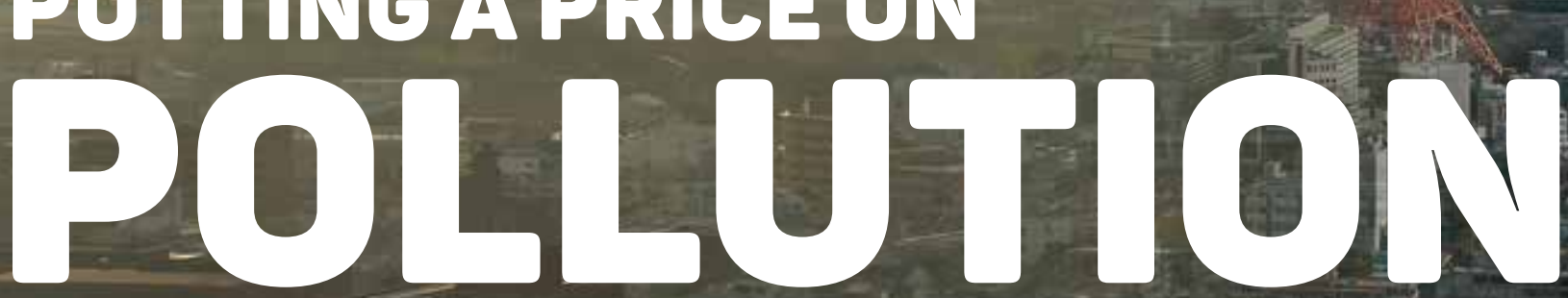

\section{Carbon-pricing strategies could hold the key to meeting the world's climate stabilization goals}

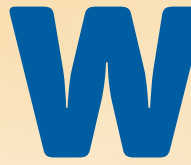

ithout major and urgent efforts to slow accumulation of carbon dioxide $\left(\mathrm{CO}_{2}\right)$ and other greenhouse gases in the atmosphere, future generations will inherit a much warmer planet with risks of dangerous climate events, higher sea levels, and destruction of the natural world.

The international community's response is grounded in the 2015 Paris Agreement, which has the key objective of limiting future global warming to between 1.5 and $2^{\circ} \mathrm{C}$ above pre-industrial levels. One hundred ninety parties submitted climate strategies for this agreement, almost all of which include mitigation commitments. A typical pledge among advanced economies is to reduce emissions by $20-40$ percent by 2030 relative to emissions in a baseline year. These pledges are voluntary, but participating parties are required to submit updated pledges every five years starting in 2020 and to routinely report progress on implementing them.

For this international response to work, policymakers need carefully crafted measures that effectively meet their mitigation commitments while at the same time limiting the burdens on their countries' economies and navigating the political obstacles to implementation. Even if successfully implemented, however, current country pledges would cut global emissions by only about one-third of the amount required to meet climate stabilization goals. Innovative mechanisms are therefore needed to scale up mitigation efforts at the international level.

\section{The case for carbon taxation}

Carbon taxes are charges on the carbon content of fossil fuels. Their principal rationale is that they are generally an effective tool for meeting domestic emission mitigation commitments. Because these taxes increase the prices of fossil fuels, electricity, and general consumer products and lower prices for fuel producers, they promote switching to lower-carbon fuels in power generation, conserving on energy use, and shifting to cleaner vehicles, among other things. A tax of, say, $\$ 35$ a ton on $\mathrm{CO}_{2}$ emissions in 2030 would typically increase prices for coal, electricity, and gasoline by about 100,25 , and 10 


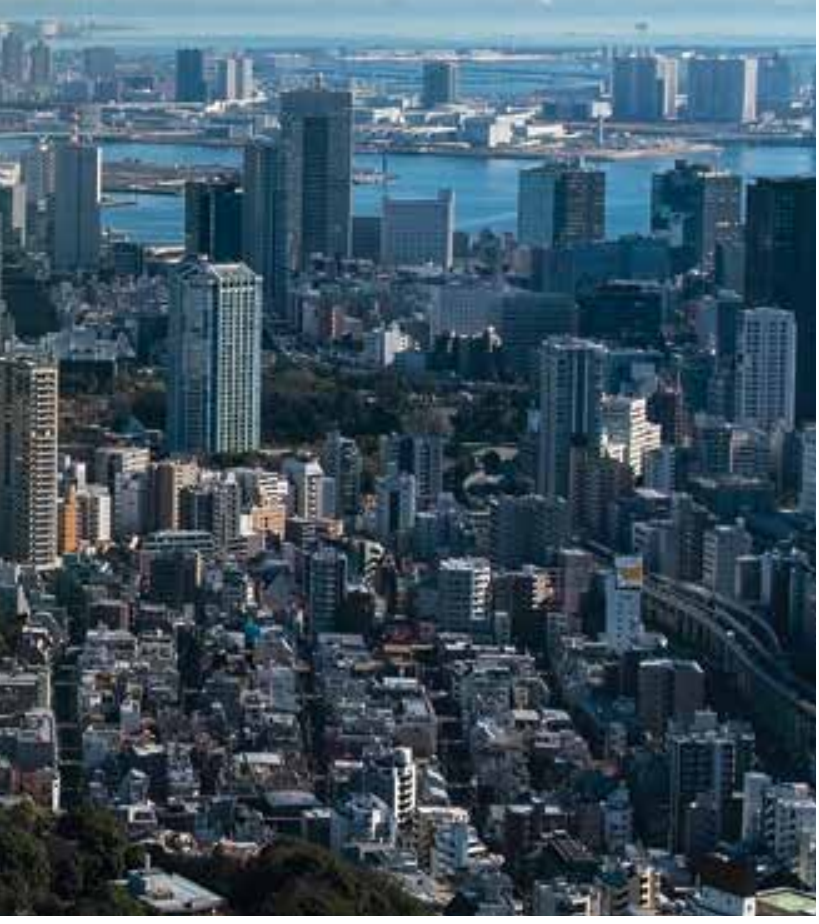

percent, respectively. Carbon taxes also provide a clear incentive for redirecting energy investment toward low-carbon technologies like renewable power plants.

A $\$ 35$ per ton carbon tax by itself would exceed the level needed to meet mitigation commitments in such countries as China, India, and South Africa, and it would be about right to meet pledges in Indonesia, the Islamic Republic of Iran, Pakistan, the United Kingdom, and the United States. But even a carbon tax as high as $\$ 70$ per ton (or equivalent measures) would fall short of what is needed in some countries like Australia and Canada (Chart 1). These findings reflect differences not only in the stringency of commitments, but also in the responsiveness of emissions to taxes: emissions are most responsive to carbon pricing in countries consuming a great deal of coal, such as China, India, and South Africa.

Another important argument for carbon taxes is that they could raise a significant amount of revenue, typically 1-2 percent of GDP for a $\$ 35$ a ton tax in 2030 (Chart 2). Using this revenue productively to benefit a country's economy could help offset the harmful macroeconomic effects-reduced employment and investment-of higher energy prices. For advanced economies, for example, the revenue might be used mostly to cut taxes on labor and capital income, implying a retooling of the tax system rather than an increase in the overall tax burden. For developing countries unable to mobilize adequate revenue from broader taxes because a substantial portion of economic activity occurs in the informal sector, carbon tax revenues might be used mostly to fund investments for achieving the United Nations Sustainable Development Goals. In all countries, use of some revenues to fund cleanenergy infrastructure upfront could enhance carbon pricing's effectiveness and credibility.

A third rationale for carbon taxes is that they can generate significant domestic environmental benefitsfor example, reductions in the number of people dying prematurely from exposure to local air pollution caused by fossil fuel combustion.

Finally, carbon taxes are straightforward to administer. Carbon charges can be integrated into existing road fuel excises, which are well established in most countries and among the easiest of taxes to collect, and applied to other petroleum products, coal, and natural gas. Another option is to integrate carbon charges into royalty regimes for extractive industries, though rebates should be provided for exported fuels as, under the Paris Agreement, countries are responsible only for emissions within their own borders.

An alternative way to price carbon emissions is through emission-trading systems in which firms are required to acquire allowances to cover their emissions, the government controls the total supply of allowances, and trading of allowances among firms establishes an emission price. To date, trading systems have been mostly limited to power generators and large industry, however, which reduces their $\mathrm{CO}_{2}$ reduction benefits by $20-50$ percent across different countries compared with more comprehensive pricing. It also limits potential revenues from auctioning allowances (similarly carbon taxes, like other types of taxes, often include exemptions). And although trading systems provide more certainty in respect to future emissions, they provide less certainty regarding emission prices, which might deter clean-technology investment. They also require new administration to monitor emissions and trading markets and significant numbers of participating firms, which may preclude their application in small or capacity-constrained countries. 


\section{Chart 1}

\section{Effect of carbon pricing}

$A \$ 35$ per ton tax on carbon emissions is easily sufficient for some countries to meet Paris mitigation pledges but others need much higher prices.

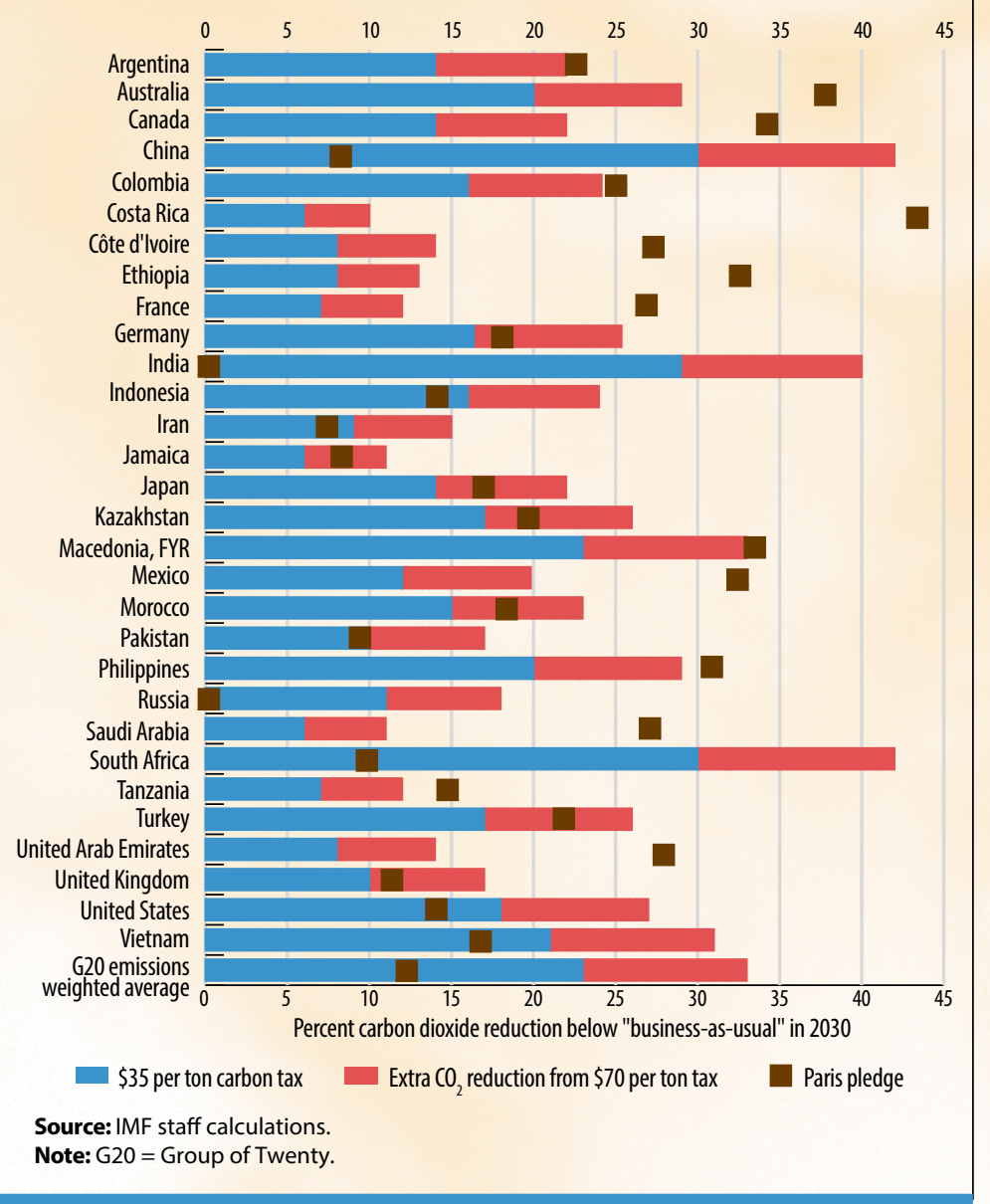

Although nearly 60 carbon tax and trading systems are in operation at the national, subnational, and regional levels in various countries, the average price of emissions worldwide is only $\$ 2$ a ton-a small fraction of what is needed. This underscores the political difficulty of ambitious pricing. Where carbon pricing is politically constrained, policymakers could reinforce it with other approaches that do not impose a new tax burden on energy and therefore avert large increases in energy prices.

A more traditional approach would be to use regulations to control things like products' energy efficiency or power generators' emission rates. In fact, a comprehensive package of regulations could mimic many, though not all, of the behavioral responses resulting from carbon pricing: regulations cannot encourage people to drive less or turn down the air conditioner, for example. Regulations also tend to be inflexible and difficult to coordinate cost-effectively across sectors and firms.

A more promising and novel alternative to regulations is revenue-neutral "feebates," which provide a sliding scale of fees for products or activities with above-average emissions intensity and rebates for those with below-average intensity. If feebates were applied to power generators, for example, producers would be paying a tax in proportion to their electricity output times the difference between their $\mathrm{CO}_{2}$ emission rate per kilowatt hour of generation and the industry-wide average emission rate.

\section{Advancing policy}

Previous experiences with carbon pricing and broader energy-pricing reform across many countries suggest some strategies for enhancing their acceptability. For example, pricing can be phased in progressively to allow businesses and households time to adjust. And an up-front package of targeted assistance, which need use only a minor fraction of the carbon-pricing revenues, can be provided for vulnerable households, firms, and communities through, for example, stronger social safety nets and worker assistance programs.

Especially important is to use the bulk of the revenues from carbon pricing transparently, equitably, and productively. A $\$ 70$ a ton carbon tax in Canada and the United States and a $\$ 35$ a ton tax in China and India would impose, through their impact on the price of energy and general consumer goods, extra bills for the average household of about 2 percent of their consumption in 2030. But if, for example, transfer payments were used to compensate the bottom 40 percent of households for the burden of higher prices, and the remaining revenue (about 70 percent) was used to benefit the country's economy through broad income tax reductions or increases in productive investment, then the bottom 40 percent of poor households in all four countries would be better off overall, while the average overall burden on higher-income households would be pretty modest, at about 1-2 percent.

By comparison, a package of feebates designed to deliver the same economy-wide emissions reductions as the tax would impose a burden on all households, but this burden would typically amount to less than 1 percent of consumption. In short, carbon mitigation policies need not impose heavy burdens on broad household groups. Communicating this message clearly to the public may help lessen public opposition to reform.

At the international level, a carbon price floor arrangement among heavily emitting countries 


\section{THE ECONOMICS OF CLIMATE}

could strengthen and reinforce the Paris Agreement mitigation process. Such an arrangement would guarantee a minimum level of effort among participants and provide some reassurance against losses in international competitiveness. Coordination in regard to price floors rather than price levels would allow countries to exceed the floors, if necessary, to meet their Paris Agreement mitigation pledges. And the floors could be designed to accommodate carbon taxes and emission-trading systems as well as other approaches like feebates that achieve the same emission outcome as would have occurred under the floor price.

There are some monitoring challenges-for example, countries would need to agree on procedures to account for possible exemptions in carbon-pricing schemes and changes in preexisting energy taxes that might offset or enhance carbon pricing's effectiveness. But these technical challenges should be manageable.

Given their lower per capita income and smaller contribution to historical atmospheric greenhouse gas accumulations, a case can be made for emerging market economies to have a lower price floor requirement than advanced economies. For illustration, if advanced and developing G20 economies were subject to carbon floor prices of $\$ 70$ and $\$ 35$ a ton of $\mathrm{CO}_{2}$, respectively, in 2030, mitigation effort would be well over twice as much as reductions implied by meeting current mitigation pledges. To reduce emissions to a level consistent with a $2^{\circ} \mathrm{C}$ target, however, additional measures-equivalent to a global average carbon price of $\$ 75$ a ton-would still be needed.

\section{Reasons for optimism?}

Just three countries-China, India, and the United States-account for about 80 percent of the lowcost mitigation opportunities across G20 countries, so a pricing arrangement among these three countries alone would be a huge step forward and should catalyze action elsewhere. That may seem wishful thinking right now-for example, the United States is set to withdraw from the Paris Agreement in 2020; coal is entrenched in India because of history, large reserves, and existing infrastructure; and China's nationwide trading system, slated for introduction in 2020, will likely have limited coverage and ambition.

Nonetheless, there are some grounds for optimism. For example, fiscal consolidation measures
Chart 2

\section{Raising revenue}

Carbon taxes could raise a significant amount of revenue, which could be used to lower other taxes or fund green initiatives and other productive investments.

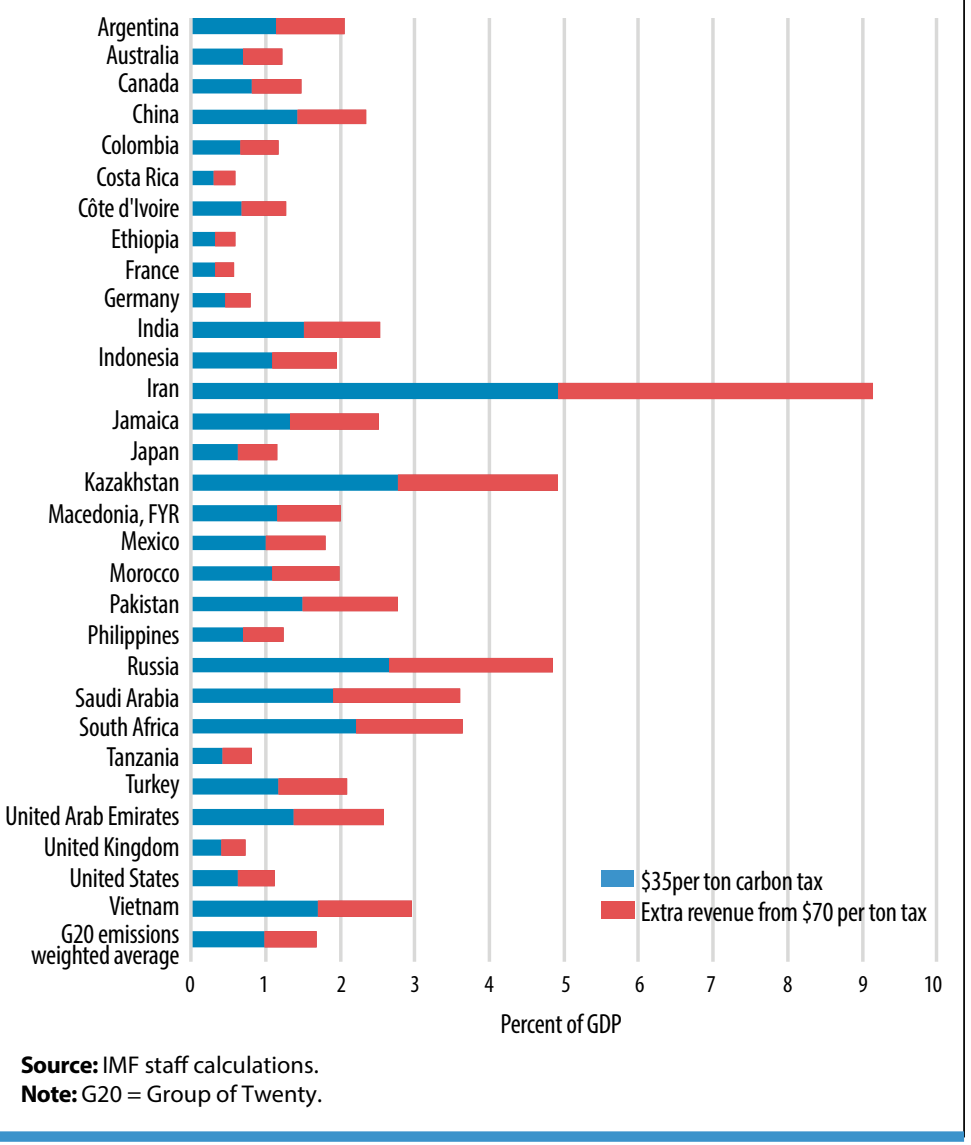

will likely be needed at some point in the United States given the longer-term budget outlook, and carbon taxation may be easier to stomach than raising taxes on businesses and households or cutting entitlements.

More immediately, there is much debate (in the United States and elsewhere) about the possibility of a Green New Deal to rapidly decarbonize economies, and carbon pricing could play a pivotal role in that. Carbon pricing is in China and India's interests when the benefits from reduced air pollution mortality are considered: a $\$ 35$ a ton carbon tax in 2030 would save an estimated 300,000 premature deaths a year in China and an estimated 170,000 in India. And it is in all countries' interests to see effective mitigation at the international level to stabilize the global climate system, avoid climate-related damages at the domestic level, and safeguard the environment for future generations. FD

IAN PARRY is principal environmental fiscal policy expert in the IMF's Fiscal Affairs Department.

This article draws on the IMF's October2019 Fiscal Monitor and "Fiscal Policies for Paris Climate Strategies_ From Principle to Practice,"IMF Policy Paper 19/010 (May 1, 2019). 


\section{The Adaptive Age}

\section{No institution or individual can stand on the sidelines in the fight against climate change}

\section{Kristalina Georgieva}

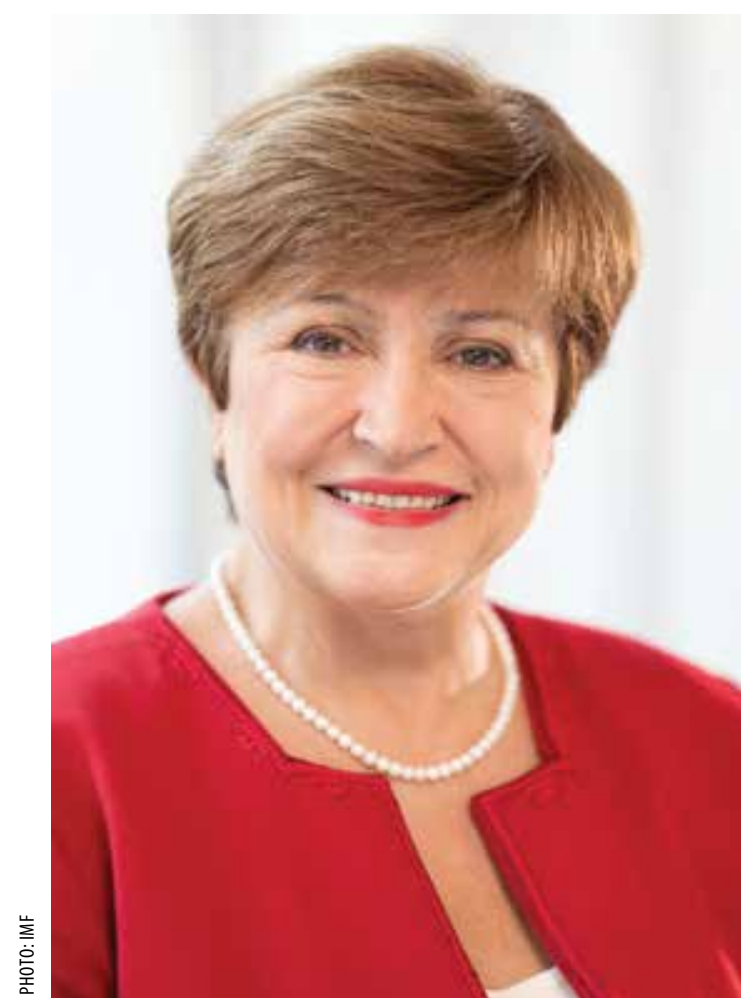

WHEN I THINK of the incredible challenges we must confront in the face of a changing climate, my mind focuses on young people. Eventually, they will be the ones either to enjoy the fruits or bear the burdens resulting from actions taken today.

I think of my 9-year-old granddaughter. By the time she turns 20, she may be witness to climate change so profound that it pushes an additional 100 million people into poverty. By the time she turns 40, 140 million may become climate migrantspeople forced to flee homes that are no longer safe or able to provide them with livelihoods. And if she lives to be 90 , the planet may be $3-4^{\circ}$ hotter and barely livable.

Unless we act. We can avoid this bleak future, and we know what we have to do-reduce emissions, offset what cannot be reduced, and adapt to new climate realities. No individual or institution can stand on the sidelines.

\section{Reality check}

Our efforts to reduce greenhouse gas emissions through various mitigation measures - phasing out fossil fuels, increasing energy efficiency, adopting renewable energy sources, improving land use and agricultural practices - continue to move forward, but the pace is too slow. We have to scale up and accelerate the transition to a low-carbon economy. At the same time, we must recognize that climate change is already happening and affecting the lives of millions of people. There are more frequent and more severe weather-related events-more droughts, more floods, more heat waves, more storms.

Ready or not, we are entering an age of adaptation. And we need to be smart about it. Adaptation is not a defeat, but rather a defense against what is already happening. The right investments will deliver a "triple dividend" by averting future losses, spurring economic gains through innovation, and delivering social and environmental benefits to everyone, but particularly to those currently affected and most at risk. Updated building codes can ensure infrastructure and buildings are better able to withstand extreme events. Making agriculture more climate resilient means investing more money in research and development, which in turn opens the door to innovation, growth, and healthier communities.

The IMF is stepping up its efforts to deal with climate risk. Our mission is to help our members build stronger economies and improve people's lives through sound monetary, fiscal, and structural policies. We consider climate change a systemic risk to the macroeconomy and one in which the IMF is deeply involved through its research and policy advice.

\section{Mitigation plus adaptation}

On the mitigation side of the equation, this means intensifying our work on carbon pricing and helping governments craft road maps as they navigate their way from brown economies dependent on carbon to green ones that strive to be carbon free. 
Carbon taxes are one of the most powerful and efficient tools at their disposal-the latest IMF analysis finds that large emitting countries need to introduce a carbon tax that rises quickly to $\$ 75$ a ton in 2030 , consistent with limiting global warming to $2^{\circ} \mathrm{C}$ or less. But carbon taxes must be implemented in a careful and growth-friendly fashion. The key is to retool the tax system in fair, creative, and efficient ways-not just add a new tax. A good example is Sweden, where low- and middle-income households received higher transfers and tax cuts to help offset higher energy costs following the introduction of a carbon tax.

This is a path others can follow, strategically directing part of the revenues that carbon taxes generate back to low-income households that can least afford to pay. With the revenues estimated at 1-3 percent of GDP, a portion could also go to support firms and households that choose green pathways.

While we continue to work to reduce carbon emissions, the increasing frequency of more extreme weather like hurricanes, droughts, and floods is affecting people all across the world. Countries already vulnerable to natural disasters suffer the most, not only in terms of immediate loss of life, but also in long-lasting economic effects. In some countries, total economic losses exceed 200 percent of GDP - as when Hurricane Maria struck Dominica in 2017.

Our emergency lending facilities are designed to provide speedy assistance to low-income countries hit by disasters. But the IMF also works across various fronts on the adaptation side to help countries address climate-related challenges and be able to price risk and provide incentives for investment, including in new technologies.

We support resilience-building strategies, particularly in highly vulnerable countries to help them prepare for and rebound from disasters. And we contribute to building capacity within governments through training and technical assistance to better manage disaster risks and responses.

We work with other organizations to increase the impact of our climate work. One of our most important partnerships is with the World Bank, in particular on Climate Change Policy Assessments. Together, we take stock of countries' mitigation and adaption plans, risk management strategies, and financing and point to gaps where those countries need investment, policy changes, or help in building up their capacity to take the necessary action.

\section{New frontiers}

Moving forward, we must also be open to stepping in where and when our expertise can help, and there are other areas where we will be gearing up our work. For example, we will be working more closely with central banks, which, as guardians of both financial and price stability, are now adapting regulatory frameworks and practices to address the multifaceted risks posed by climate change.

Many central banks and other regulators are seeking ways to improve climate risk disclosure and classification standards, which will help financial institutions and investors better assess their climate-related exposures-and help regulators better gauge system-wide risks. The IMF is offering support by working with the Network of Central Banks and Supervisors for Greening the Financial System and other standard-setting bodies.

\section{Ready or not, we are entering an age of adaptation. And we need to be smart about it.}

Central banks and regulators should also help banks, insurers, and nonfinancial firms assess their own exposures to climate risk and develop climate-related "stress tests." Such tests can help identify the likely impact of a severe adverse climate-driven shock on the solvency of financial institutions and the stability of the financial system. The IMF will help push forward efforts around climate change stress testing, including through our own assessments of countries' financial sectors and economies. Careful calibration of stress testing for climate change will be needed, because such testing requires assessing the effects of shocks or policy actions that may have little historical precedent.

All these efforts will help ensure that more money will flow into low-carbon, climate-resilient investments. The rapid increase of green bonds is a positive trend, but much more is required to secure our future. It is that simple: we all need to intensify our efforts to work together to exchange knowledge and ideas, to formulate and implement policies, and to finance the transition to the new climate economy. Our children and grandchildren are counting on us. FD

KRISTALINA GEORGIEVA is managing director of the IMF. 


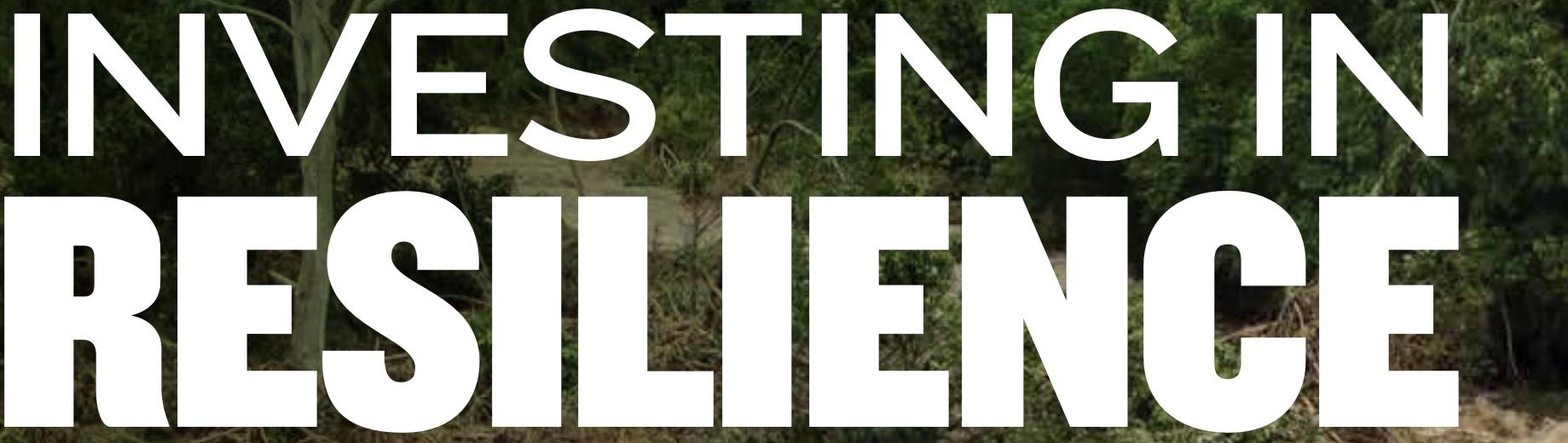

Disaster-prone countries are strengthening their ability to withstand climate events Bob Simison
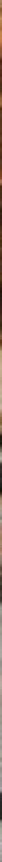

422 FINANCE \& DEVELOPMENI | December 2019 -

CInternational Monetary Fund. Not for Redistribution 


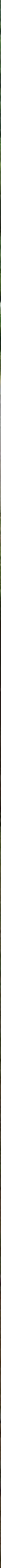


Monetary Fund, and the World Bank. Investing in resilience is likely to result in less human suffering and fewer lives lost than simply pouring resources into relief and recovery after disasters, these groups are finding.

In June 2019, the IMF endorsed investment in resilience building by disaster-prone nations, citing lower expected losses, improved economic performance, and better continuity of public services. It acknowledged, however, that many vulnerable countries are likely to find such investments unaffordable. According to the United Nations Environment Programme, the costs of adapting to climate change in developing economies may range from $\$ 56$ billion to $\$ 300$ billion by 2030 , or two to three times the currently available funding.

And yet, according to IMF economists, investing in resilience may cut the costs of postdisaster intervention by at least half. It's a case that international organizations are making to donor groups and nations.

"Never let a good crisis go to waste," writes former Rockefeller Foundation President Judith Rodin in her 2014 book The Resilience Dividend. Rodin continues to advocate adaptation to climate change.

"Disasters help get people's attention," she says in an interview. "Before this concept was fully developed, people didn't tend to rebuild resiliently. Everywhere, it's the poor and vulnerable who get hit the hardest, whether they live on an island or in a city."

In March 2019, Tropical Cyclone Idai blasted Malawi, Mozambique, and Zimbabwe with days of high winds and heavy rains, killing more than 1,300 people. A month later, Tropical Cyclone Kenneth hit some of the same areas and compounded the devastation, bringing total damages from the two storms to $\$ 4$ billion. It was the first instance on record of such sequential disasters in a single season and left almost 3 million people without housing, electricity, or running water. More than 800,000 hectares of crops were wiped out.

"Malawi is one of the least developed countries in the world and also one of the countries hardest hit by climate change," says Pritha Mitra, the IMF's mission chief for Malawi. "We are looking at adapting to climate change and whether it's actually an opportunity to not only boost growth, but also reduce inequality. In sub-Saharan African countries, the people who are most affected by climate change are the poorer households, so climate change is exacerbating already-large inequalities."
In the cyclones' aftermath, the African Development Bank approved a $\$ 100$ million, fouryear grant program that would directly benefit 1 million people across the three countries. The project includes measures to improve agricultural productivity and resilience by upgrading irrigation systems and livestock practices. In addition, it envisions making infrastructure such as roads, electrical grids, water supplies, and sanitation systems more resistant to big storms. The program will also enhance early-warning systems and institutional and community capacity to respond to disasters.

Farmers and remote households in places like Malawi depend on mobile-phone services for early warning of weather events, planning what crops to plant, and gaining access to financing, Mitra says. So strengthening telecommunications systems to withstand catastrophic storms is important for building resilience, she observes.

"These countries can't necessarily do it all on their own," Mitra says. "These are poor countries. As the disasters become bigger and more frequent, and thus more costly for all the various donor countries and international organizations, perhaps it is going to be cheaper if we all help with building resilience up front."

That's a major takeaway from a 2019 working paper by IMF economists Alessandro Cantelmo, Giovanni Melina, and Chris Papageorgiou. These researchers rank countries by probability of sustaining a natural disaster based on 20 years of data through 2017. They identify the 34 most disaster-prone nations and find that they are mostly small or low-income countries in the Pacific or the Caribbean, with the Marshall Islands, St. Vincent and the Grenadines, Tuvalu, Micronesia, and St. Lucia at the top of the list.

The study shows that natural disasters such as droughts, floods, and storms can often cause damages totaling 50 percent of a country's GDP, with indications that frequency and size of catastrophes have risen over the past 20 years. The costs of Hurricane Ivan for Grenada in 2004 amounted to 148 percent of GDP and those of Hurricane Maria for Dominica in 2017 reached 260 percent, reflecting the relatively small size of the countries' economies.

Small nations can't just bounce back from calamities on that scale. On average, the economies of disasterprone countries grow by 1 percent less each year than those of non-disaster-prone countries because major resources have to be diverted to recovery 
from such calamities, the researchers find. Climate change may triple that growth gap, the study shows. As their economies stagnate and revenues decline, disaster-prone nations carry significantly higher public debt than non-disaster-prone countries.

The researchers have developed a complex economic model to compare the effects of investing in resilience with those of simply providing disaster relief. It shows that disaster-prone countries would benefit only modestly by self-financing the higher costs of adaptation. "International aid is crucial," they write. If forthcoming, such help in paying for resilient infrastructure can yield dramatic results, the economists find.

"To eliminate the welfare losses from natural disasters via grants that finance the extra cost of resilient infrastructure, donors would have to disburse less than half the amount required to finance post-disaster intervention," the study shows.

Other recent IMF work in Caribbean nations has shown that investing in structural resilience would increase potential economic output by 3-11 percent, with a growth dividend of $0.1-0.4$ percent a year.

The IMF has outlined a three-legged approach to disaster resilience that is consistent with maintaining fiscal sustainability. Countries need to get their fiscal houses in order, with supportive funding from the international community because of the scale of the costs involved.

The first element of the approach is structural adaptation, such as strengthened roads, bridges, telecommunications, water supplies, and sanitation systems. The tiny Caribbean island of Dominica, with a population of 74,000 , was devastated by tropical systems in 2015 and 2017. Damages the first time equaled the country's GDP and the second time amounted to twice its GDP. Under an IMF pilot program, Dominica's government is developing a plan to improve the resilience of the nation's infrastructure by 2030 . But doing so in a fiscally sustainable way will require donor aid totaling \$200 million, the IMF estimates.

A second leg is postdisaster and social resilience, such as contingency planning and related investments to ensure an efficient disaster response with minimal disruption to public services, such as those for sheltering people and knowing where to direct relief. For example, following a 2016 cyclone, Mozambique created a social registry for use in distributing supplies after a disaster while investing in stronger schoolhouses that function as community shelters, says IMF African Department adviser Marshall Mills.

The third pillar, and really the central one, is creating financial resilience in advance of disasters, according to Uma Ramakrishnan, an assistant director in the IMF's Western Hemisphere Department and a lead author of the IMF's paper on building resilience in disaster-prone developing nations. Her portfolio includes The Bahamas, Barbados, and Jamaica. She cites a recent six-and-a-half-year IMF project in which Jamaica put tremendous effort into strengthening its finances so that major external shocks, including a major storm, won't irreversibly damage the nation's fiscal capacity. Over nearly 300

\section{Everywhere, it's the poor and vulnerable who get hit the hardest, whether they live on an island or in a city.}

years of recorded history, Jamaica has weathered dozens of hurricanes, including 17 named storms since 1951, usually causing flooding, fatalities, and economic devastation.

As a first layer of financial resilience, Jamaica has been pouring money into a contingency fund to provide ready cash in the event of a disaster. The fund has reached about J $\$ 2$ billion ( $\$ 15$ million), according to Ramakrishnan. A second is arranging standby financing for catastrophes in the form of a \$285 million credit line from the Inter-American Development Bank. And a third is arranging disaster insurance through various risk-transfer mechanisms, including the Caribbean Catastrophe Risk Insurance Facility and a possible market-based instrument such as a catastrophe bond, although details regarding the instrument aren't fully public.

"There is more to be done in Jamaica on structural and social resilience, and that will come next," Ramakrishnan says. "In Jamaica, they always say they are just one hurricane away from all their economic gains being wiped out." FD

BOB SIMISON is a freelance writer and editor who previously worked at the Wall Street Journal, the Detroit News, and Bloomberg News. 


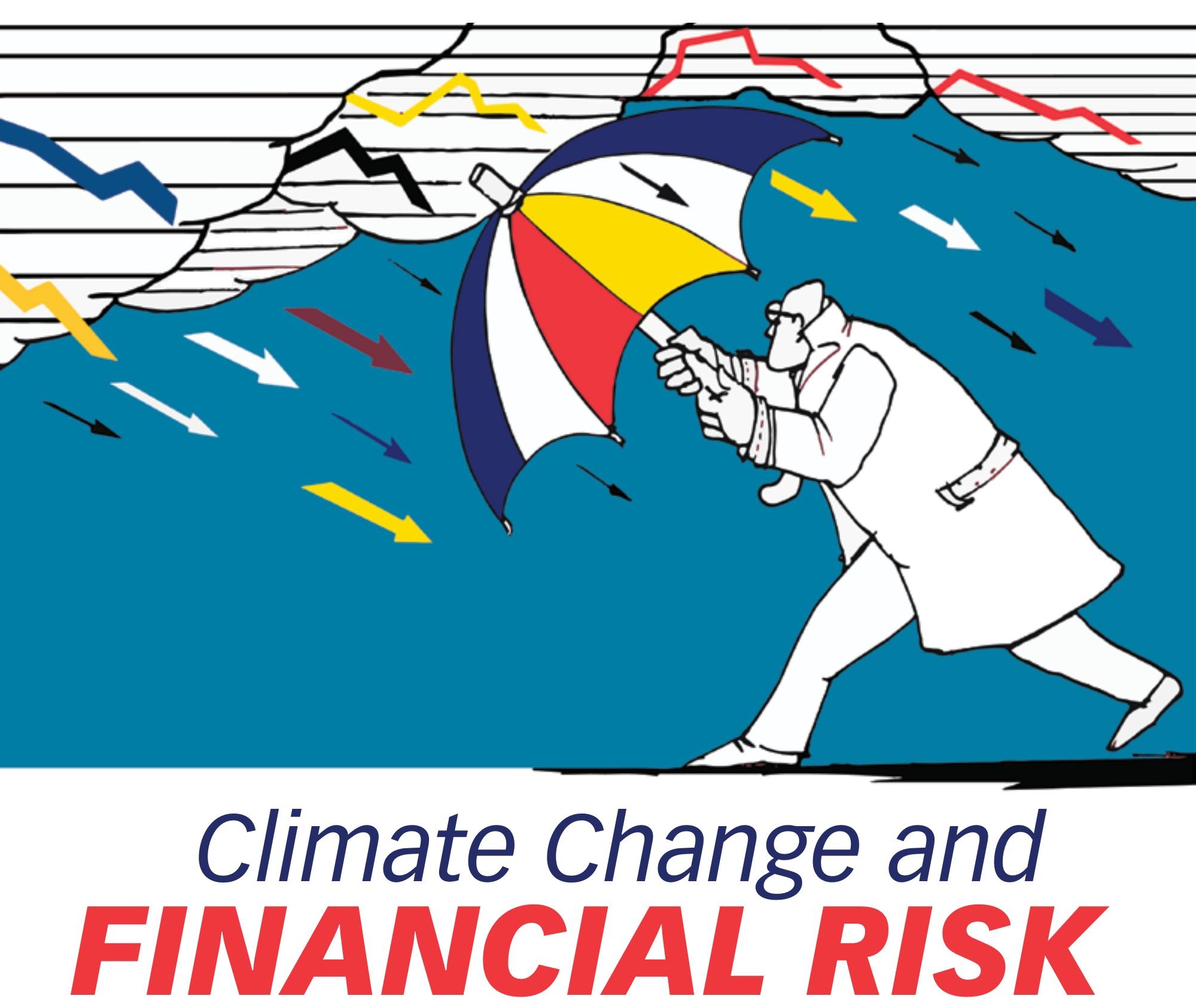

Central banks and financial regulators are starting to factor in climate change

\section{Pierpaolo Grippa, Jochen Schmittmann, and Felix Suntheim}

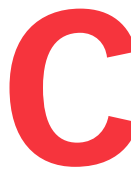

limate change is already a reality. Evermore-ferocious cyclones and extended droughts lead to the destruction of infrastructure and the disruption of livelihoods and contribute to mass migration. Actions to combat rising temperatures, inadequate though they may have been so far, have the potential to drive dislocation in the business world as fossil fuel giants awaken to the need for renewable sources of energy and automakers accelerate investments in cleaner vehicles.

But measuring economic costs of climate change remains a work in progress. We can assess the immediate costs of changing weather patterns and more frequent and intense natural disasters, but most of the potential costs lie beyond the horizon of the typical economic analysis. The economic impact of climate change will likely accelerate, though not smoothly. Crucially for the coming generations, the extent of the damage will depend on policy choices that we make today.

Policymakers and investors increasingly recognize climate change's important implications for the financial sector. Climate change affects the financial system through two main channels (see Chart 1). The first involves physical risks, arising from damage to property, infrastructure, and land. The second, transition risk, results from changes in climate policy, technology, and consumer and market sentiment during the adjustment to a lower-carbon economy. Exposures can vary significantly from country to country. Lower- and 


\section{Physical and transition risks}

The risks from climate change to the economy have two basic channels, but many potential impacts.
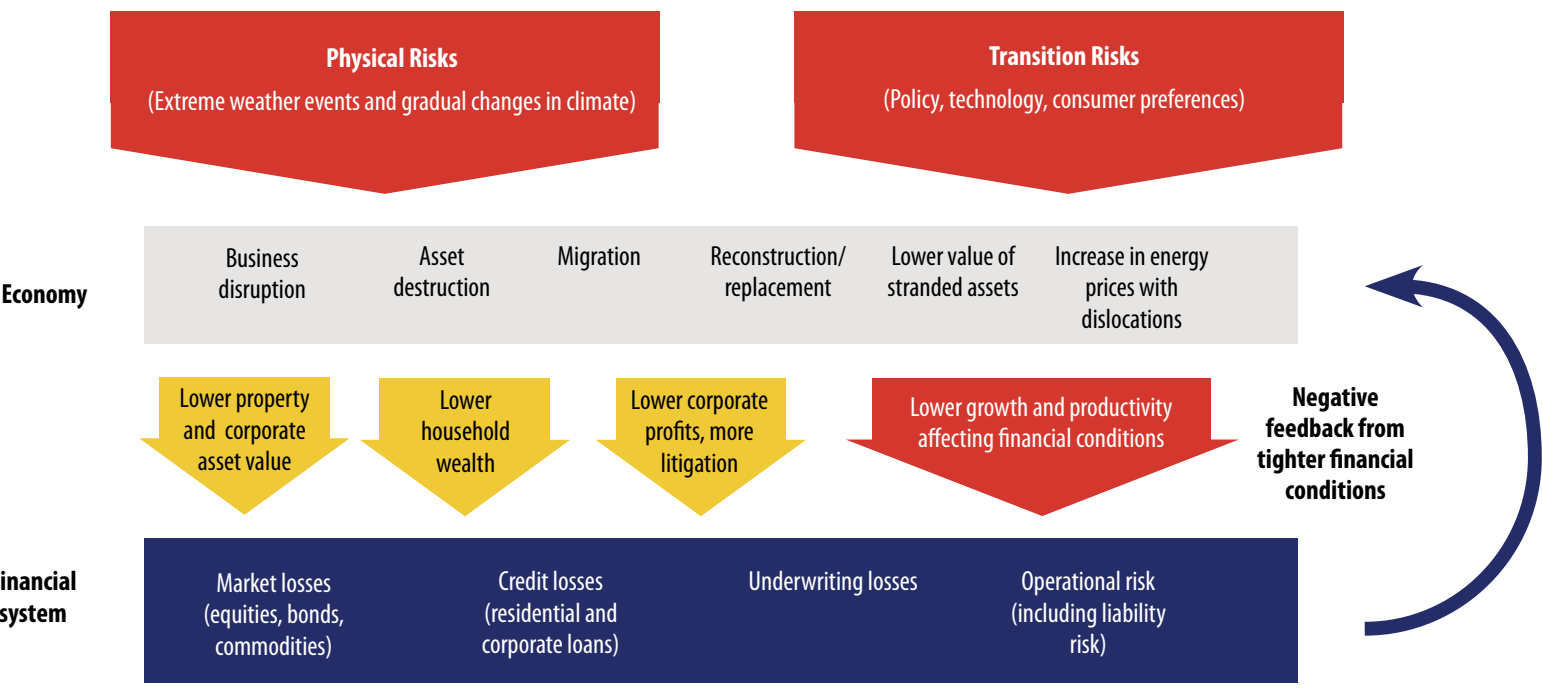

middle-income economies are typically more vulnerable to physical risks.

For financial institutions, physical risks can materialize directly, through their exposures to corporations, households, and countries that experience climate shocks, or indirectly, through the effects of climate change on the wider economy and feedback effects within the financial system. Exposures manifest themselves through increased default risk of loan portfolios or lower values of assets. For example, rising sea levels and a higher incidence of extreme weather events can cause losses for homeowners and diminish property values, leading to greater risks in mortgage portfolios. Corporate credit portfolios are also at risk, as highlighted by the bankruptcy of California's largest utility, Pacific Gas and Electric. In what The Wall Street Journal called the first "climate-change bankruptcy" (Gold 2019), rapid climatic changes caused prolonged droughts in California that dramatically increased the risk of fires from Pacific Gas and Electric's operations. Tighter financial conditions might follow if banks reduce lending, in particular when climate shocks affect many institutions simultaneously.

For insurers and reinsurers, physical risks are important on the asset side, but risks also arise from the liability side as insurance policies generate claims with a higher frequency and severity than originally expected. There is evidence that losses from natural disasters are already increasing. As a result, insurance is likely to become more expensive or even unavailable in at-risk areas of the world. Climate change can make banks, insurers, and reinsurers less diversified, because it can increase the likelihood or impact of events previously considered uncorrelated, such as droughts and floods.

Transition risks materialize on the asset side of financial institutions, which could incur losses on exposure to firms with business models not built around the economics of low carbon emissions. Fossil fuel companies could find themselves saddled with reserves that are, in the words of Bank of England Governor Mark Carney (2015), "literally unburnable" in a world moving toward a low-carbon global economy. These firms could see their earnings decline, businesses disrupted, and funding costs increase because of policy action, technological change, and consumer and investor demands for alignment with policies to tackle climate change. Coal producers, for example, already grapple with new or expected policies curbing carbon emissions, and a number of large banks have pledged not to provide financing for new coal facilities. The share prices of US coal mining companies reflect this "carbon discount" as well as higher financing costs and have been underperforming relative to those of companies holding clean energy assets.

Risks can also materialize through the economy at large, especially if the shift to a low-carbon economy proves abrupt (as a consequence of prior inaction), poorly designed, or difficult to coordinate globally (with consequent disruptions to international trade). Financial stability concerns 
arise when asset prices adjust rapidly to reflect unexpected realizations of transition or physical risks. There is some evidence that markets are partly pricing in climate change risks, but asset prices may not fully reflect the extent of potential damage and policy action required to limit global warming to $2^{\circ} \mathrm{C}$ or less.

Central banks and financial regulators increasingly acknowledge the financial stability implications of climate change. For example, the Network of Central Banks and Supervisors for Greening the Financial System (NGFS), an expanding group that currently comprises 48 members, has embarked on the task of integrating climate-related risks into supervision and financial stability monitoring.

Given the large shifts in asset prices and catastrophic weather-related losses that climate change may cause, prudential policies should adapt to recognize systemic climate risk-for example, by requiring financial institutions to incorporate climate risk scenarios into their stress tests. In the United Kingdom, prudential regulators have incorporated climate change scenarios into stress tests of insurance firms that cover both physical and transition risks.

Efforts to incorporate climate-related risks into regulatory frameworks face important challenges, however. Capturing climate risk properly requires assessing it over long horizons and using new methodological approaches, so that prudential frameworks adequately reflect actual risks. It is crucial to ensure that the efforts to bring in climate risk strengthen, rather than weaken, prudential regulation. Policies such as allowing financial institutions to hold less capital against debt simply because the debt is labeled as green could easily backfirethrough increased leverage and financial instability-if the underlying risks in that debt have not been adequately understood and measured.

Climate change will affect monetary policy, too, by slowing productivity growth (for example, through damage to health and infrastructure) and heightening uncertainty and inflation volatility. This can justify the adaptation of monetary policy to the new challenges, within the limits of central bank mandates. Central banks should revise the frameworks for their refinancing operations to incorporate climate risk analytics, possibly applying larger haircuts to assets materially exposed to physical or transition risks. Central banks can also lead by example by integrating sustainability considerations into the investment decisions for the portfolios under their management (i.e., their own funds, pension funds and, to the extent possible, international reserves), as recommended by the NGFS (2019) in its first comprehensive report.

\section{Financial sector contribution}

Carbon pricing and other fiscal policies have a primary role in reducing emissions and mobilizing revenues (see "Putting a Price on Pollution" in this issue of $F \& D$ ), but the financial sector has an important complementary role. Financial institutions and markets already provide financial protection through insurance and other risksharing mechanisms, such as catastrophe bonds, to partly absorb the cost of disasters.

But the financial system can play an even more fundamental role, by mobilizing the resources needed for investments in climate mitigation (reducing greenhouse gas emissions) and adaptation (building resilience to climate change) in response to price signals, such as carbon prices. In other words, if policymakers implement policies to price in externalities and provide incentives for the transition to a low-carbon economy, the financial system can help achieve these goals efficiently. Global investment requirements for addressing climate change are estimated in the trillions of US dollars, with investments in infrastructure alone requiring about $\$ 6$ trillion per year up to 2030 (OECD 2017). Most of these investments are likely to be intermediated through the financial system. From this point of view, climate change represents for the financial sector as much a source of opportunity as a source of risk.

The growth of sustainable finance (the integration of environmental, social, and governance criteria into investment decisions) across all asset classes shows the increasing importance that investors attribute to climate change, among other nonfinancial considerations. Estimates of the global asset size of sustainable finance range from $\$ 3$ trillion to $\$ 31$ trillion. While sustainable investing started in equities, strong investor demand and policy support spurred issuance of green bonds, growing the stock to an estimated $\$ 590$ billion in August 2019 from $\$ 78$ billion in 2015. Banks are also beginning to adjust their lending policies by, for example, giving discounts on loans for sustainable projects.

Sustainable finance can contribute to climate change mitigation by providing incentives for firms to adopt less carbon-intensive technologies 
and specifically financing the development of new technologies. Channels through which investors can achieve this goal include engaging with company management, advocating for low-carbon strategies as investor activists, and lending to firms that are leading in regard to sustainability. All these actions send price signals, directly and indirectly, in the allocation of capital.

However, measuring the impact that sustainable investments have on their environmental targets remains challenging. There are concerns over unsubstantiated claims of assets' green-compliant nature, known as "greenwashing." There is a risk that investors may become reluctant to invest at the scale necessary to counter or mitigate climate change, especially if policy action to address climate change is lagging or insufficient.

\section{The IMF's role}

The analysis of risks and vulnerabilities — and advising its members on macro-financial policies-are at the core of the IMF's mandate. The integration of climate change risks into these activities is critical given the magnitude and global nature of the risks climate change is posing to the world.

An area where the IMF can especially contribute is understanding the macro-financial transmission of climate risks. One aspect of this is further improving stress tests, such as those within the Financial Sector Assessment Program, the IMF's comprehensive and in-depth analysis of member countries' financial sectors.

Stress testing is a key component of the program, with these stress tests often capturing the physical risks related to disasters, such as insurance losses and nonperforming loans associated with natural disasters. Assessments for The Bahamas and Jamaica are recently published examples, with a scenario-based stress test analyzing the macroeconomic impact of a severe hurricane in the former and a massive natural disaster in the latter. More assessments of this kind are in progress or planned for other countries. The IMF is also conducting an analysis of financial system exposure to transition risk in an oil-producing country.

The IMF has recently joined the NGFS and is collaborating with its members to develop an analytical framework for assessing climate-related risks.

Closing data gaps is also crucial. Only with accurate and adequately standardized reporting of climate risks in financial statements can investors discern companies' actual exposures to climaterelated financial risks. There are promising efforts to support private sector disclosures of such risks. But these disclosures are often voluntary and uneven across countries and asset classes. Comprehensive climate stress testing by central banks and supervisors would require much better data. The IMF supports public and private sector efforts to further spread the adoption of climate disclosures across markets and jurisdictions, particularly by following the recommendations of the Task Force on Climaterelated Financial Disclosures (2017). Greater standardization would also improve the comparability of information in financial statements on climate risks.

The potential impact of climate change compels us to think through, in an empirical fashion, the economic costs of climate change. Each destructive hurricane and every unnaturally parched landscape will chip away at global output, just as the road to a low-carbon economy will escalate the cost of energy sources as externalities are no longer ignored and old assets are rendered worthless. On the other hand, carbon taxes and energy-saving measures that reduce the emission of greenhouse gases will drive the creation of new technologies. Finance will have to play an important role in managing this transition, for the benefit of future generations. FD

PIERPAOLO GRIPPA is a senior economist and FELIX SUNTHEIM is a financial sector expert in the IMF's Monetary and Capital Markets Department. JOCHEN SCHMITTMANN is the IMF's resident representative in Singapore.

This article draws on Chapter 6 of the October 2019 Global Financial Stability Report and was prepared under the guidance of Martin Čihák and Evan Papageorgiou of the IMF's Monetary and Capital Markets Department.

\section{References:}

Carney, Mark. 2015. "Breaking the Tragedy of the Horizon-Climate Change and Financial Stability." Speech delivered at Lloyd's of London, September 29. https://www.bankofengland.co.uk/speech/2015/ breaking-the-tragedy-of-the-horizon-climate-change-and-financial-stability Gold, Russell. 2019. “PG\&E: The First Climate-Change Bankruptcy, Probably Not the Last." Wall Street Journal, January 18. https://www.wsj.com/articles/ pg-e-wildfires-and-the-first-climate-change-bankruptcy-11547820006

NGFS (Network of Central Banks and Supervisors for Greening the Financial System). 2019. A Call for Action: Climate Change as a Source of Financial Risk. Paris: NGFS Secretariat. https://www.ngfs.net/en/first-comprehensive-report-call-action

OECD (Organisation for Economic Co-operation and Development). 2017. Investing in Climate, Investing in Growth. Paris: OECD Publishing. http://dx.doi. org/10.1787/9789264273528-en

Task Force on Climate-related Financial Disclosures. 2017. Final Report: Recommendations of the Task Force on Climate-related Financial Disclosures. Basel. https://www.fsb-tcfd. org/publications/final-recommendations-report/ 

central Africa to make room for pasture illustrate the dramatic trade-offs between cattle ranching, biological diversity, and the planet's eroding ability to absorb human-emitted carbon dioxide.

As the global population grows and more people demand animal products, achieving targets to limit climate change will become harder. Without action, by 2030 the livestock sector alone could account for 37 percent of the emissions allowable to keep warming under the $2^{\circ} \mathrm{C}$ target, and 49 percent if the temperature goal is $1.5^{\circ} \mathrm{C}$, according to estimates by Helen Harwatt of Harvard University.

Beyond its direct impact on climate change, the agri-food sector uses a lot of the planet's resources, including about half the world's ice- and desert-free land and three-quarters of its fresh water. Farming depletes these resources because of routine discharges of pollutants, like pesticides, synthetic fertilizers, and manure; discharges of genetically modified organisms and sediment to surface and groundwater; and loss of topsoil as well as salinization and waterlogging of irrigated land. Current farming methods have been found to degrade soil more than 100 times faster than new soil is formed. Agriculture is also the prime cause of earth's current mass extinction, according to the UN's Intergovernmental Science-Policy Platform on Biodiversity and Ecosystem Services (2019).

Worst of all, current food systems have failed to fulfill their promise to secure food for humanity. With a third of all food produced going to the more than 70 billion animals farmed every year on land alone, more than 820 million people worldwide went hungry in 2018, according to the Food and Agriculture Organization. Meanwhile, 650 million people were classed as obese and about 2 billion as overweight, because they ate too much of the wrong things.

\section{$1.5^{\circ} \mathrm{C}$ target for food}

Making food systems sustainable for a growing global population is technologically possible but involves a fundamental reconsideration of production and consumption-namely, a Great Food Transformation.

On the supply side, three changes are necessary. First, global production and consumption of red meat (especially beef) and dairy will need to be cut by about 50 percent, through substitution of proteins supplied by plants. Urgent action in the top three beef (United States, Brazil, European
Union) and dairy (United States, India, China) producers is key.

Second, a large-scale shift is needed away from conventional monoculture agriculture toward practices that support biodiversity, such as organic and mixed crop-livestock farming, sustainable soil management, and ecosystem restoration. Denmark and the Netherlands were among the first countries to announce ambitious organic transformation plans. Restoring soils with regenerative practices (e.g., planting cover crops and perennials and eliminating monocultures) could lock up as much as 60 tons of carbon in soil and vegetation per acre, thus reducing levels of carbon dioxide in the atmosphere. Rattan Lal of Ohio State University, a leading soil expert, has calculated that "a mere 2 percent increase in the carbon content of the planet's soils could offset 100 percent of all greenhouse gas emissions."

Regenerative ocean farming can both sequester carbon and restore ecosystems. According to the World Bank, ocean farming of seaweed and shellfish in an area equivalent to 5 percent of U.S. territorial waters can produce protein equivalent to 2.3 trillion hamburgers and sequester carbon equal to the output of 20 million cars. And farming less than 10 percent of the oceans could absorb all carbon produced in a year globally and produce enough biofuel to power the world, calculates the University of Melbourne's Tim Flannery.

Third, better land use, such as planting forests and reducing deforestation, will be an integral part of limiting climate change since intact forests sequester twice as much carbon as planted monocultures. A proposed companion pact to the Paris Agreement - a Global Deal for Nature - targets 30 percent of earth to be formally protected and an additional 20 percent designated as climate stabilization areas, by 2030 , to hold global temperature increases below $1.5^{\circ} \mathrm{C}$.

If sizeable and consistent, these three changes combined can slash emissions, boost carbon sequestration from arable soil, release land for crops and forests, halt biodiversity and pollinator loss, and restore global freshwater resources.

Changes in supply and land use must be accompanied by a shift in diets toward more and more diverse plant-based foods, such as coarse grains, pulses and vegetables, and nuts and seeds. Research published in Nature in 2018 concluded that while undernourished people could actually eat a little 


\section{Rising share}

By 2050, the share of greenhouse gas emissions produced by the agri-food sector is expected to rise to half of the total compared with a quarter of the total today.

(Share of greenhouse gas from agriculture, fishery, and land use in total greenhouse gas, percent)

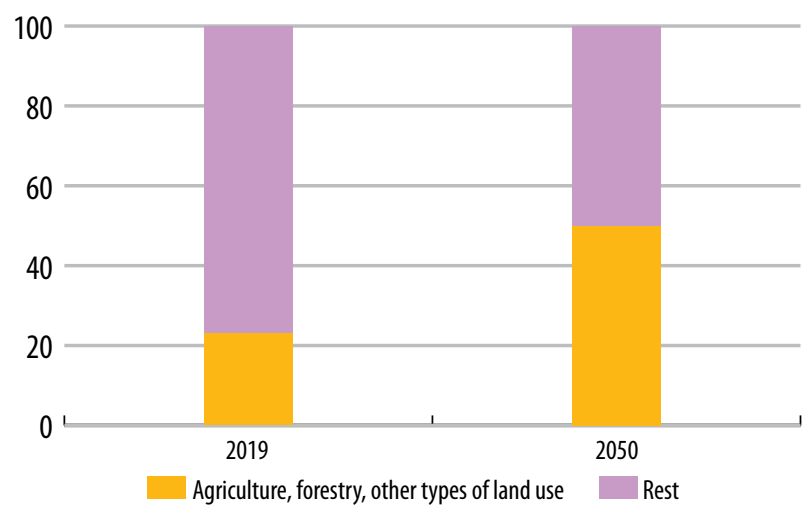

Sources: Intergovernmental Panel on Climate Change (2019); Willett and others (2019). Note: Excluding greenhouse gases from food and nonfood transformation.

more meat and dairy, the average world citizen should eat 50 percent less, an easy-to-remember rule being "no animal products for breakfast or lunch." Predominantly plant-based diets are key not only for the planet (Chart 2), but also for people, as they slash the risk of cancer, cardiovascular diseases, type 2 diabetes, and obesity.

\section{The role of policy}

Well-targeted economic, financial, and trade policies, as well as structural reforms, can go a long way toward delivering these goals. Currently, in many countries, large amounts of taxpayers' money are spent on subsidies that encourage otherwise unprofitable, unsustainable meat and dairy production predicated on the systematic inhumane treatment of farmed animals, as well as growing monoculture commodity crops for animal feed. (In 2018, total subsidies to agriculture in OECD member countries reached $\$ 233$ billion, an amount comparable to Greece's GDP.) Even more taxpayers' money then goes to fixing the resulting problems: water and air pollution, animal-borne pandemics, anti-microbial resistances, and the impacts of unhealthy diets. Subsidies for unsustainable farming in advanced economies also discourage private investment in agriculture in developing economies, leaving their consumers dependent on imported food and exposed to volatile international food prices.

These subsidies should be redirected toward sustainable farms producing plant-based protein for human consumption and toward incentives for innovation on alternative proteins and smart farming technologies. Transitional technical and financial assistance, including direct loans, guarantee schemes, crop insurance, and measures to improve land and market access, should be provided to help farmers transition to organic practice. Currently a mere 1.2 percent of global agricultural land is farmed organically, a figure expected to reach only 3.2 percent by 2024 under current policies.

In developing economies, replacing production subsidies with ecological payments to sustainable farmers could reorient industrial agriculture, adding to the climate mitigation potential, while reducing negative impacts on farm incomes. Focusing efforts on women farmers and indigenous people and enhancing local and community collective action is particularly effective, according to researchers at the University of Colorado at Boulder.

Also needed are measures to foster aggressive conservation. These could include land tenure legislation and financial and labor market incentives favoring landowners who protect ecosystems, especially in regions that host the planet's rainforests. Governments should make the adoption of on-farm conservation practices a condition for receiving farm subsidies. At the international level, a fund could be set up to compensate countries for forgoing trade in commodities whose production threatens critical ecosystems. Similar funds could be established to create new or enforce existing marine conservation areas in critical ecosystems zones, on the blueprint of the conservation successes of the Chilean and Argentinian governments in creating marine parks in the Patagonian sea.

Climate-smart technologies and practices are emerging, including methods to expand biomass energy production from crop and food wastes, manure management, renewable energy-based farming systems, solar- or wind-powered water pumping, drip irrigation, innovative greenhouse technologies, and efficient field machinery. Still critically needed are additional public-private early warning systems for weather, crop yields, and seasonal climate events and public support for innovation in sustainability-enhancing agricultural technology.

Just as carbon tax proposals aim to reduce the carbon footprint of the energy sector, taxes levied on "unsustainable" and "unhealthy" foods—notably meat, dairy, and ultra-processed food — could discourage their overconsumption, bringing consumption in line with scientific nutritional recommendations. 
The average US retail price of a Big Mac, for example, is around \$5.60. But with all the hidden expenses of meat production (including health care, subsidies, and environmental losses) the full burden on society is a hefty $\$ 12$ per sandwich-a price that, if actually charged, could more than halve the US demand for burgers, according to estimates by David Robinson Simon, author of the 2014 book Meatonomics. Likewise, a gallon of milk would run $\$ 9$ instead of $\$ 3.50$ and a store-bought, twopound package of pork ribs would jump from $\$ 12$ to $\$ 32$. Offsetting these taxes with lower taxes on sustainable foods would ensure that consumers' food purchasing power would not be diminished, while health and environmental gains would still save the United States tens of billions of dollars in net terms every year.

Public policies should also be used to cut food waste. Better supply chain management to limit food rotting in the field, e-commerce platforms sharing real-time information about surplus and demand, smaller retail portions, greater use of frozen food, donations programs for unused food, educational campaigns to build waste consciousness, and reducing excess consumption can make a tremendous dent in food waste emissions.

On the financial side, changes to prudential regulation to properly account for financial risks of institutions that lend to nonsustainable agrifood firms would provide essential support to a Great Food Transformation. A bolder approach to investment of public funds in assets associated with sustainable land use and steps to expand green and sustainable bond markets could help fund the transition.

\section{Extraordinary co-benefits}

It is hard to overstate the planetary benefits of greening the agri-food sector. The IPCC's 2019 report indicates that by 2050, reforms of crop and livestock activities and agroforestry could mitigate up to a third of all greenhouse-gas emissions, while dietary changes alone could lead to a reduction in emissions equal to the sum of the current annual carbon emissions of the United States and India. The elimination of food waste could cut another 810 percent of the world's carbon emissions. Shifting production and consumption toward plant-based foods would also halt deforestation and enable conservation of critical ecosystems.
Chart 2

\section{Diet matters}

Limiting or eliminating meat from one's diet can help reduce carbon emissionsif everyone followed a vegan diet, emissions could be reduced significantly.

(Demand-side greenhouse gas mitigation potential, gigatons of carbon dioxide equivalent per year)

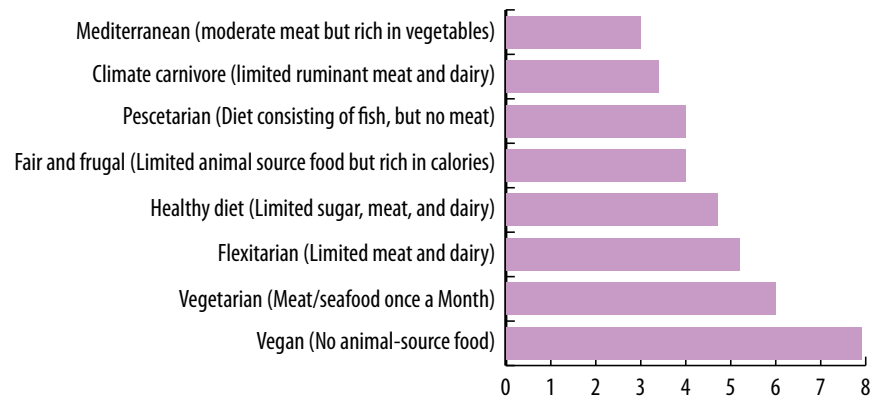

Source: Intergovernmental Panel on Climate Change (2019).

For humans and our offspring, beyond securing our planet's habitability and biological richness, the wins would be comparably vast. The food we eat would be more nutritious, more varied, safer, more humanely raised, and more affordable. We would live longer and healthier lives. Savings from lower health costs - one of the top expenditure categories for governments and households-could stabilize global finances. Labor productivity would rise with fewer work years lost because of ill-health, disability, or early death. Critical progress would be made in eradicating world hunger, income inequality, and social immobility, averting mass migration due to climate change.

Climate health is land and seas' health is human health is economies' health. If we can muster the will before it is too late, we can have our nutritious food, thriving economies, and a habitable planet too. FD

NICOLETTA BATINI is a senior economist in the IMF's Independent Evaluation Office.

\section{References:}

Batini, Nicoletta. 2019. “Transforming Agri-Food Sectors to Mitigate Climate Change: The Role of Green Finance." Quarterly Journal of Economic Research, 88, no. 3: 7-42.

Harwatt, Helen. 2018. "Including Animal to Plant Protein Shifts in Climate Change Mitigation Policy: A Proposed Three-Step Strategy." Climate Policy 19, no. 5: 533-41.

Intergovernmental Panel on Climate Change (IPCC). 2019. Climate Change and Land: An IPCC Special Report on Climate Change, Desertification, Land Degradation, Sustainable Land Management, Food Security, and Greenhouse Gas Fluxes in Terrestrial Ecosystems. Geneva.

Intergovernmental Science-Policy Platform on Biodiversity and Ecosystem Services (IPBES) 2019. Global Assessment Report on Biodiversity and Ecosystem Services. Bonn, Germany.

Willett, Walter, Johan Rockström, Brent Loken, and others. 2019. "Food in the Anthropocene: The EAT-Lancet Commission on Healthy Diets from Sustainable Food Systems." Lancet 393 (10170): 447-92. 



\section{CHART 1}

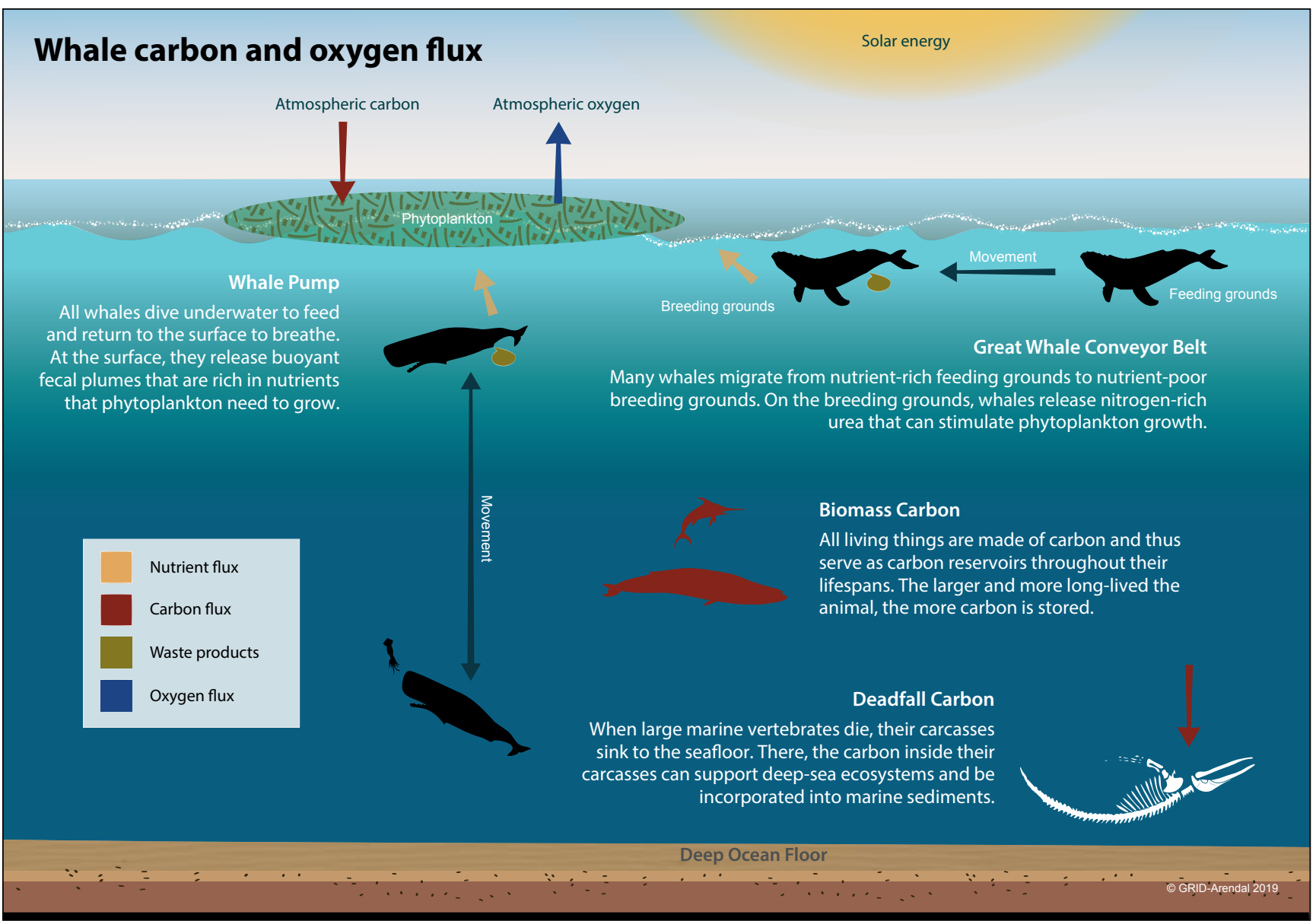

(REDD) that fund the preservation of carboncapturing ecosystems.

Adapting these initiatives to support international efforts to restore whale populations could lead to a breakthrough in the fight against climate change.

The carbon capture potential of whales is truly startling. Whales accumulate carbon in their bodies during their long lives. When they die, they sink to the bottom of the ocean; each great whale sequesters 33 tons of $\mathrm{CO}_{2}$ on average, taking that carbon out of the atmosphere for centuries. A tree, meanwhile, absorbs only up to 48 pounds of $\mathrm{CO}_{2}$ a year.

Protecting whales could add significantly to carbon capture because the current population of the largest great whales is only a small fraction of what it once was. Sadly, after decades of industrialized whaling, biologists estimate that overall whale populations are now less than one-fourth what they once were. Some species, like the blue whales, have been reduced to only 3 percent of their previous abundance. Thus, the benefits from whales' ecosystem services to us and to our survival are much less than they could be.

But this is only the beginning of the story.

\section{The whale pump}

Wherever whales, the largest living things on earth, are found, so are populations of some of the smallest, phytoplankton. Not only do these microscopic creatures contribute at least 50 percent of all oxygen to our atmosphere, they do so by capturing about 37 billion metric tons of $\mathrm{CO}_{2}$, an estimated 40 percent of all $\mathrm{CO}_{2}$ produced. To put things in perspective, we calculate that this is equivalent to the amount of $\mathrm{CO}_{2}$ captured by 1.70 trillion trees-four Amazon forests' worth - or 70 times the amount absorbed by all the trees in the US Redwood National and State Parks each year. More phytoplankton means more carbon capture.

In recent years, scientists have discovered that whales have a multiplier effect of increasing 
phytoplankton production wherever they go. How? It turns out that whales' waste products contain exactly the substances-notably iron and nitrogen-phytoplankton need to grow. Whales bring minerals up to the ocean surface through their vertical movement, called the "whale pump," and through their migration across oceans, called the "whale conveyor belt" (see Chart 1). Preliminary modeling and estimates indicate that this fertilizing activity adds significantly to phytoplankton growth in the areas whales frequent.

Despite the fact that nutrients are carried into the ocean through dust storms, river sediments, and upwelling from wind and waves, nitrogen and phosphorus remain scarce and limit the amount of phytoplankton that can bloom in warmer parts of the oceans. In colder regions, such as in the Southern Ocean, the limiting mineral tends to be iron. If more of these missing minerals became available in parts of the ocean where they are scarce, more phytoplankton could grow, potentially absorbing much more carbon than otherwise possible.

\section{Letting whales live}

This is where the whales come in. If whales were allowed to return to their prewhaling number of 4 to 5 million-from slightly more than 1.3 million today - it could add significantly to the amount of phytoplankton in the oceans and to the carbon they capture each year. At a minimum, even a 1 percent increase in phytoplankton productivity thanks to whale activity would capture hundreds of millions of tons of additional $\mathrm{CO}_{2}$ a year, equivalent to the sudden appearance of 2 billion mature trees. Imagine the impact over the average lifespan of a whale, more than 60 years.

Despite the drastic reduction in commercial whaling, whales still face significant life-threatening hazards, including ship strikes, entanglement in fishing nets, waterborne plastic waste, and noise pollution. While some species of whales are recovering — slowly_many are not.

Enhancing protection of whales from humanmade dangers would deliver benefits to humans, the planet, and of course, the whales themselves. This "earth-tech" approach to carbon sequestration also avoids the risk of unanticipated harm from suggested untested high-tech fixes. Nature has had millions of years to perfect her whale-based carbon sink technology. All we need to do is let the whales live.
Now we turn to the economic side of the solution. Protecting whales has a cost. Mitigating the many threats to whales involves compensating those causing the threats, a group that includes countries, businesses, and individuals. Ensuring that this approach is practical involves determining whales' monetary value.

\section{International public good}

Whales produce climate benefits that are dispersed all over the globe. And because people's benefits from the existence of whales do not diminish the benefits that others receive from them, they are a textbook public good (see Chart 2). This means that whales are affected by the classic "tragedy of the commons" that afflicts public goods: no individual who benefits from them is sufficiently motivated to pay his or her fair share to support them. Just think of the importance of earth's atmosphere to humans' survival. Even though all nations acknowledge that everyone has an interest in preserving this common resource for the future, global coordination remains a problem.

To solve this international public goods problem, we must first ask, What is the monetary value of a whale? Proper valuation is warranted if businesses and other stakeholders are to be galvanized to save the whales by showing that the benefits of protecting them far exceed the cost. We estimate the value of an average great whale by determining today's value of the carbon sequestered by a whale over its lifetime, using scientific estimates of the amount whales contribute to carbon sequestration, the market price of carbon dioxide, and the financial technique of discounting. To this, we also add today's value of the whale's other economic contributions, such as fishery enhancement and ecotourism, over its lifetime. Our conservative estimates put the value of the average great whale, based on its various activities, at more than $\$ 2$ million, and easily over $\$ 1$ trillion for the current stock of great whales.

But there is still the question of how to reduce the myriad dangers to whales, such as ship strikes and other hazards. Luckily, economists know how these types of problems can be solved. In fact, a potential model for such solutions is the United Nations (UN) REDD program. Recognizing that deforestation accounts for 17 percent of carbon emissions, REDD provides incentives for countries to preserve their forests as a means of keeping $\mathrm{CO}_{2}$ out of the atmosphere. In a similar way, we can create financial mechanisms to promote the restoration 


\section{The whale is an international public good}

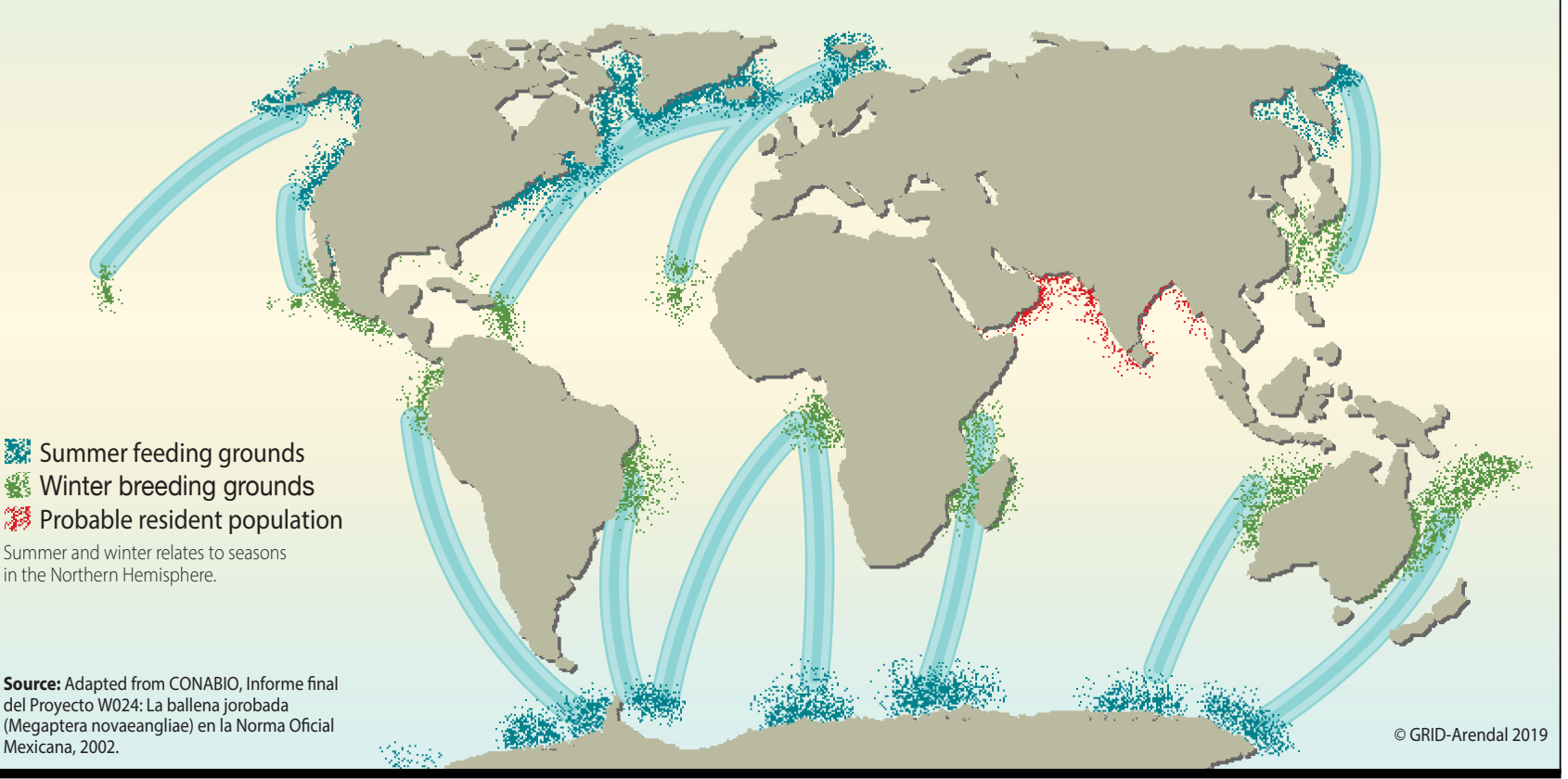

of the world's whale populations. Incentives in the form of subsidies or other compensation could help those who incur significant costs as a result of whale protection. For example, shipping companies could be compensated for the cost of altered shipping routes to reduce the risk of collisions.

This solution, however, raises questions that are tricky to answer. To begin with, a financial facility for protecting whales and other natural assets must be set up and funded. Exactly how much should we be willing to spend on protecting the whales? We estimate that, if whales were allowed to return to their prewhaling numbers-capturing 1.7 billion tons of $\mathrm{CO}_{2}$ annually-it would be worth about $\$ 13$ a person a year to subsidize these whales' $\mathrm{CO}_{2}$ sequestration efforts. If we agree to pay this cost, how should it be allocated across countries, individuals, and businesses? How much should each individual, company, and country that must bear some of the cost of protecting whales be compensated? And who will oversee the compensation and monitor compliance with the new rules?

International financial institutions, in partnership with other UN and multilateral organizations, are ideally suited to advise, monitor, and coordinate the actions of countries in protecting whales. Whales are commonly found in the waters around low-income and fragile states, countries that may be unable to deal with the needed mitigation measures. Support for these countries could come, for example, from the Global Environment Facility, which typically provides support to such countries to meet international environmental agreements. The IMF is also well placed to help governments integrate the macroeconomic benefit that whales provide in mitigating climate change, as well as the cost of measures to protect the whales, into their macro-fiscal frameworks. The World Bank has the expertise to design and implement specific programs to compensate private sector actors for their efforts to protect whales. Other UN and multilateral organizations can oversee compliance and collect data to measure the progress of these efforts.

\section{A new mindset}

Coordinating the economics of whale protection must rise to the top of the global community's climate agenda. Since the role of whales is irreplaceable in mitigating and building resilience to climate change, their survival should be integrated into the objectives of the 190 countries that in 2015 signed the Paris Agreement for combating climate risk. 


\section{CHART 3}

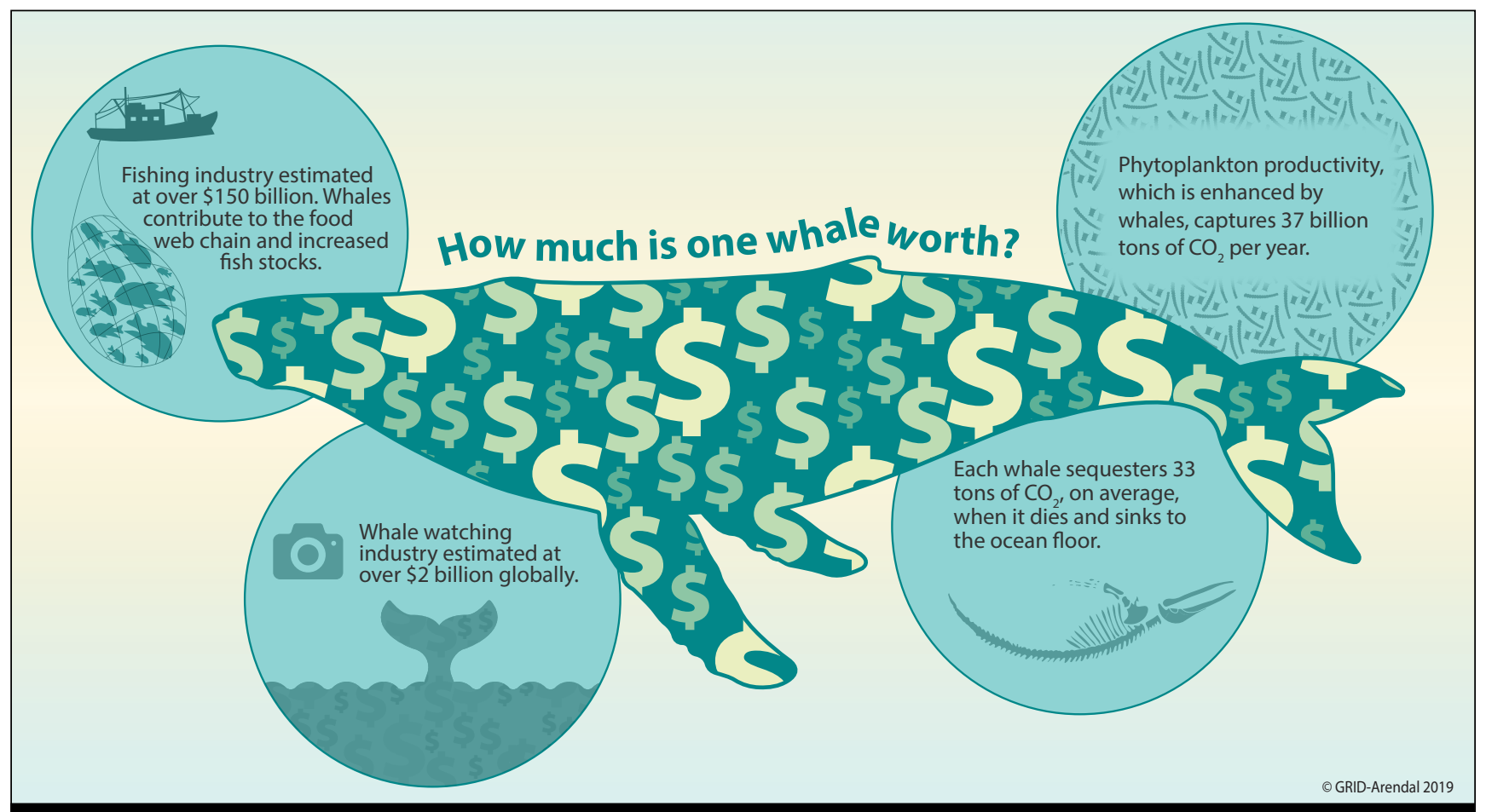

International institutions and governments, however, must also exert their influence to bring about a new mindset - an approach that recognizes and implements a holistic approach toward human survival, which involves living within the bounds of the natural world. Whales are not a human solution-these great creatures having inherent value of their own and the right to live-but this new mindset recognizes and values their integral place in a sustainable ocean and planet. Healthy whale populations imply healthy marine life including fish, seabirds, and an overall vibrant system that recycles nutrients between oceans and land, improving life in both places. The "earth-tech" strategy of supporting whales' return to their previous abundance in the oceans would significantly benefit not only life in the oceans, but also life on land, including our own.

With the consequences of climate change here and now, there is no time to lose in identifying and implementing new methods to prevent or reverse harm to the global ecosystem. This is especially true when it comes to improving the protection of whales so that their populations can grow more quickly. Unless new steps are taken, we estimate it would take over 30 years just to double the number of current whales and several generations to return them to their prewhaling numbers. Society and our own survival can't afford to wait this long. FD

RALPH CHAMI is an assistant director and SENA OZTOSUN is a research analyst in the IMF's Institute for Capacity Development, THOMAS COSIMANO is professor emeritus at the University of Notre Dame's Mendoza College of Business, and CONNEL FULLENKAMP is professor of the practice of economics and director at Duke University's Economics Center for Teaching.

\section{References:}

Lavery, T., B. Roudnew, P. Gill, J. Seymour, L. Seuront, G. Johnson, J. Mitchell, and V. Smetacek. 2010. "Iron Defecation by Sperm Whales Stimulates Carbon Export in the Southern Ocean." Proceedings of the Royal Society B: Biological Sciences 277, no. 1699:3527-31.

\section{Lutz, S., and A. Martin. 2014. Fish Carbon: Exploring Marine Vertebrate Carbon Services. Arendal, Norway: GRID-Arendal.}

Pershing, A., L. Christensen, N. Record, G. Sherwood, and P. Stetson. 2010. “The Impact of Whaling on the Ocean Carbon Cycle: Why Bigger Was Better." PLoS One 5, no. 8:1-9.

Roman, J., J. Estes, L. Morissette, C. Smith, D. Costa, J. McCarthy, J. B. Nation, S. Nicol, A. Pershing, and V. Smetacek. 2014. "Whales as Marine Ecosystem Engineers" Frontiers in Ecology and the Environment 12, no. 7: 377-85.

Smith, C., J. Roman, and J. B. Nation. 2019. "A Metapopulation Model for Whale-Fall Specialists: The Largest Whales Are Essential to Prevent Species Extinctions - The Sea."Unpublished. 


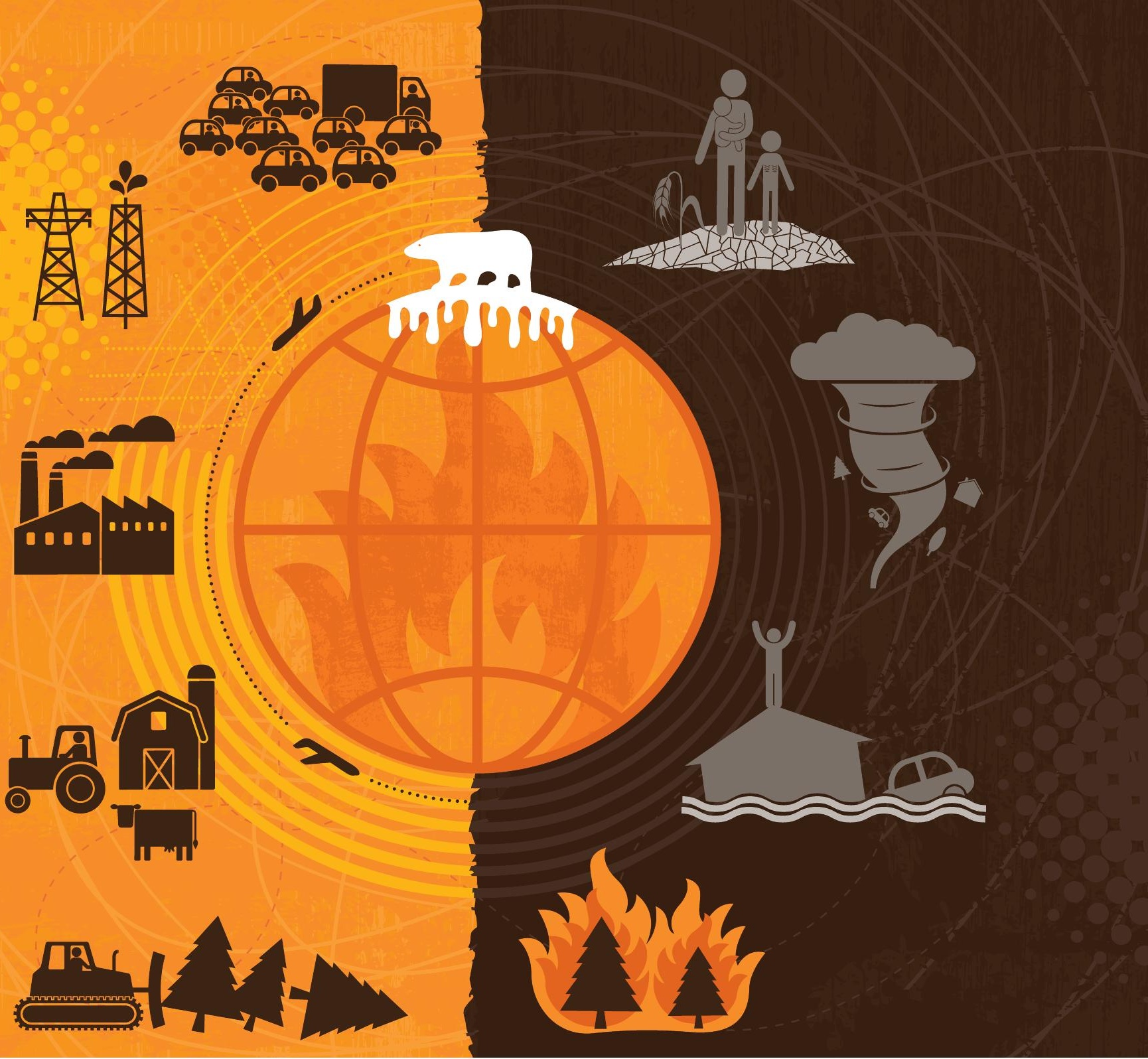

\section{Tackling Inequality}

How can we address inequality in the twenty-first century? Start with climate change.

\section{Lyndsay Walsh}

o you prefer to hear good news or bad news first? I will begin by giving you the (unsurprisingly) bad news. Today's world is an unequal place. Standards of living vary massively both between and within countries. To narrow it down to its most blunt statistic, if you were born in Hong Kong Special Administrative Region, your life expectancy is nearly double that of someone born in Swaziland, 84 and 49 years, respectively.

The good news is that in recent decades many global indicators of living standards have improved. The United Nations' Millennium Development
Goals, a group of targets aimed at reducing poverty and raising living standards, were largely successful. Those living in extreme poverty dropped from 1.9 billion in 1990 to 836 million in 2015, the proportion of undernourished people in lowincome countries fell from 23 percent in 1990 to 13 percent in 2014, and worldwide primary school enrollment has reached 90 percent. These statistics offer hope for a trajectory toward an equal world. There is more bad news, however, in that climate change threatens to undo this progress and create further inequity. 


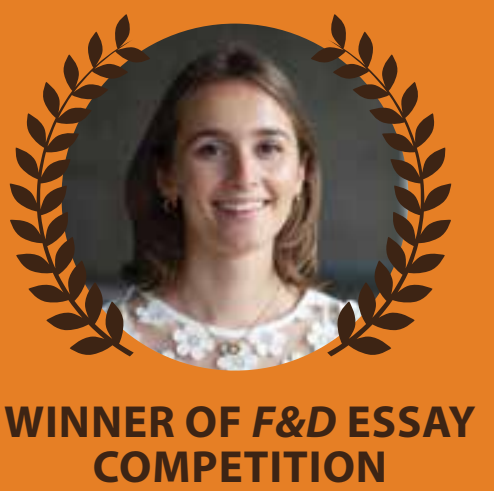

Lyndsay Walsh is the winner of $F \& D$ 's first-ever essay competition, announced in our December 2018 issue.

The competition, open to graduate students worldwide, called for students to submit their thoughts on how the problem of inequality can be tackled. F\&D received submissions from over two dozen countries. Walsh is studying for a master's in development practice at Trinity College Dublin in Ireland.

Climate change will be the definitive challenge of the twenty-first century, yet it is largely pushed aside in discussions of policies to address inequality. If warming is not limited to $1.5^{\circ} \mathrm{C}$ above preindustrial levels, the results could nullify most, if not all, the progress made in reducing inequality. Climate change will further magnify existing inequality as low- and middle-income countries will bear the brunt of its impact. As rainfall patterns become more unpredictable, sea levels rise, and storms become more intense, the expected impacts on low-income countries are severe.

\section{Unequal impact}

An integral problem of advocating for action is that people perceive climate change as a distant threat, but its ramifications are already being witnessed in many parts of the world. Cities such as Dakar in Senegal are flooded annually. The semiarid Sahel region is encroaching on once-fertile farmland. California was subjected to the deadliest wildfires in its history last year, with record amounts of land burned to ash.

Climate change is an exemplary illustration of inequality in the twenty-first century. The United States is responsible for 26 percent of global cumulative greenhouse gases, and Europe is responsible for an additional 22 percent. In contrast, the entire continent of Africa contributes just 3.8 percent. While high-income countries are responsible for the vast majority of greenhouse gas emissions, it is the lowincome countries that will face the repercussions. Many low-income countries are located in the tropics, which are far more vulnerable to rising temperatures than high-income temperate countries such as the United Kingdom. Entire agricultural systems will be lost, famines will hit numerous areas, and diseases such as malaria are predicted to become more widespread. Already we are seeing pastoral farmers in Chad struggling to survive due to a lengthening dry season. The largest lake in the country, Lake Chad, has shrunk 90 percent in the past 50 years.

Nevertheless, this division is not solely between high- and low-income countries; it will also prevail within countries. Last year Harvard researchers coined the term "climate gentrification": properties at higher elevations in inland Miami were becoming more expensive because of flooding risks associated with climate change. Again, it will be those who cannot afford to buy their way to safety who are left in at-risk areas.

Along with creating new problems for low-income countries, climate change will exacerbate existing inequalities. Low-income countries do not have the fiscal capacity to deal with severe disruptions to infrastructure. Increased flooding will lead to the spread of waterborne diseases such as cholera and dysentery owing to damaged water provisioning services. Cases of malnutrition are expected to rise dramatically as droughts in tropical areas result in lower crop yields. In countries such as Madagascar, where over 70 percent of the population are rural farmers, this will be devastating. As a result of the complex and far-reaching nature of climate change, the knock-on effects for low-income countries are multitudinous. It will make receiving a quality education more difficult, intensify existing gender inequalities, provoke conflict, destabilize governments, and force people to leave their homelands. These countries do not have the funds or support to deal with the scale of the problems climate change will bring.

"Climate migrant" is a term we will hear frequently; the World Bank predicts there may be up to 140 million such migrants by 2050. In Europe, the media often refer to refugees seeking security as a "crisis," yet 84 percent of refugees are currently within low-income countries, and people in poorer countries are roughly five times more likely to be displaced by weather events. This is yet another burden low-income countries are left to 


\section{Until climate change is mitigated and vulnerable countries are helped to adapt to its impacts, no true progress can be made in the quest to tackle inequality.}

deal with. Even high-income countries threatened by climate change are far more able to deal with its consequences. Shanghai, one of the cities most vulnerable to flooding, has been building flooddefense infrastructure since 2012; one such project is expected to cost $£ 5$ billion. Low-income countries do not have such capital to invest.

\section{Stepping up to the plate}

This brings us to the main question: What can be done to tackle the problem? Many things, actually. The two main aspects of dealing with climate change are mitigation and adaptation. As high-income countries produce the majority of greenhouse gas emissions, the onus is on us to minimize them.

It seems that climate scientists are finally winning the battle of awareness, as a recent poll found that 73 percent of Americans now believe that climate change is occurring, a record high. Furthermore, 72 percent said it was personally important to them. This is significant because it puts the burden on governments and companies to act in citizens' interests. Mobilizing the public to put pressure on these groups will be the true turning point, and there are already signs of this happening. Over 70,000 people marched in Brussels in January demanding better climate action from the government, and citizen groups all over the world-including in Ireland, where I am writing this - are taking their governments to court over lack of action on climate change.

The key point is that minimizing emissions sooner rather than later is an imperative as it is ultimately the cheaper and easier option. While there has been a focus on individual actions in reducing emissions, such as choosing low-emission transportation and buying seasonal produce, it is about time that governments and the private sector stepped up to the plate.

CDP's 2017 Carbon Majors Report found that just 100 companies have produced over 70 percent of global industrial greenhouse gas emissions since 1988. This statistic gives us an opening to create proper, systemic change through demanding better practice from these corporations. The private sector has a great ability to bring about lasting change not only by mitigating climate change, but also by bringing people out of poverty through employment. As many countries turn toward nationalism, the private sector is one of only a few candidates in the search for a climate leader. That said, climate change will not be mitigated without governmental cooperation through environmental policies such as carbon taxes, national adaptation plans, and participation in multilateral treaties. Economic activity in the twentieth century was largely based on fossil fuels, and carbon taxation will speed up development and adoption of alternative fuel sources. Climate change is a transboundary issue and requires global collaboration to both mitigate its effects and assist lower-income countries with adaptation.

Mitigation and adaptation are not a silver bullet for tackling existing inequalities across the world. This will be achieved through policymaking and reform of tax systems in conjunction with tackling climate change. However, I chose to write about climate change as I found it was largely sidelined in discussions surrounding inequality. Until climate change is mitigated and vulnerable countries are helped to adapt to its impacts, no true progress can be made in the quest to tackle inequality.

If inequality is truly an issue that high-income countries care about, as they claim to, then they will not let climate change continue on its current pathway to devastating low-income populations. At present we are certainly not on track to limit atmospheric warming to $1.5^{\circ}$ by the end of this century. We are not even on track to limit it to $3^{\circ}$. According to current estimates we will reach $4^{\circ}$ warming by 2100 , a year that babies born today in places like Hong Kong Special Administrative Region (but not Swaziland) will live to see. With young activists like Greta Thunberg, the 16-year-old who gave an impassioned climate advocacy speech at the United Nations, I have hope that future leaders will act on this issue, but we cannot afford to wait for them. We need climate leaders now. FD

LYNDSAY WALSH is a graduate in natural sciences of Trinity College Dublin, where she is currently studying for a master's in development practice. 


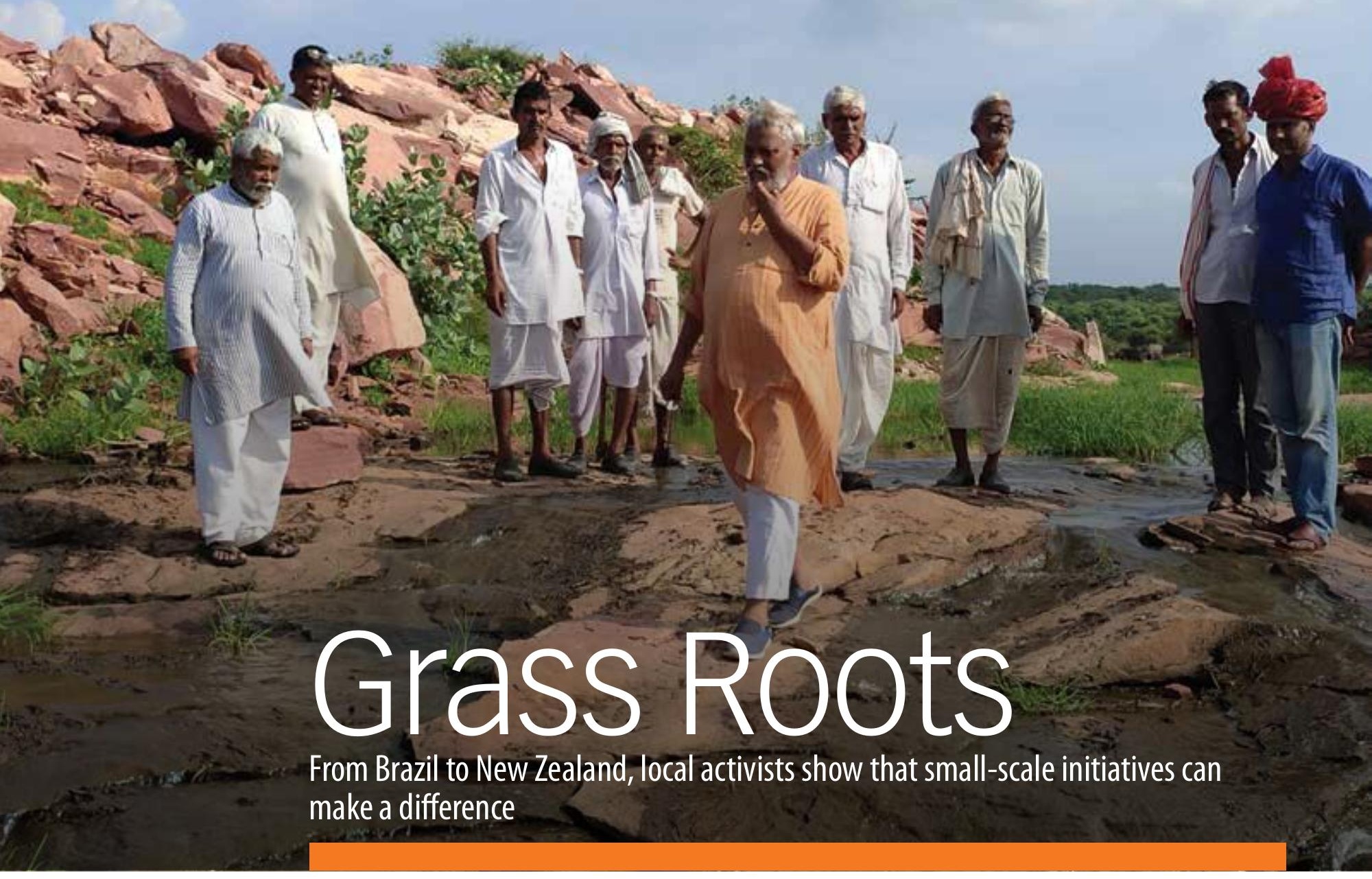

n India, a civil servant gives up his desk job to show villagers how to conserve water and overcome drought. On a Pacific Ocean atoll, a fishing guide helps fellow islanders build a sustainable tourism industry. And in New Zealand, a retired urban couple are restoring native plant species on their farm. They are among the many people across the world who are pitching in to mitigate climate change. These are their stories.

\section{Waterman of India}

Rajendra Singh set out to cure the sick. He ended up taking on a far bigger problem: the shortage of water in India, a drought-plagued country with 17 percent of the world's population but just 4 percent of its freshwater resources. It's a crusade that has earned him the moniker "Waterman of India."

In 1983, Singh quit an unrewarding civil service job to take advantage of his training in Ayurveda, an Indian system of medicine based on herbal remedies. He moved from Jaipur, the capital of the northern state of Rajasthan, to Gopalpura, a small village where a number of people suffered from night blindness, a condition in developing countries caused by vitamin A deficiency.

"I wanted to set up an Ayurvedic clinic to help cure them," Singh says. "While I did do that as well, the people in the village underscored the fact that their immediate crisis was one of water."

One of Singh's patients told him about johads, traditional reservoirs made of rocks and earth. Singh, the son of a farmer, quickly understood the need for the reservoirs, which capture rainwater and so help prevent a decline in the water table. He enlisted the help of several friends and a few villagers to build the first johad, in 1985 .

"There weren't many people as most had migrated to the city as a result of water scarcity in the village," Singh, 63, explains. "Most often it was the women in the village who helped."

He persuaded villagers to overcome caste divisions and work together. "That was the only way water would become a collective and community project," he says. It took more than eight months 


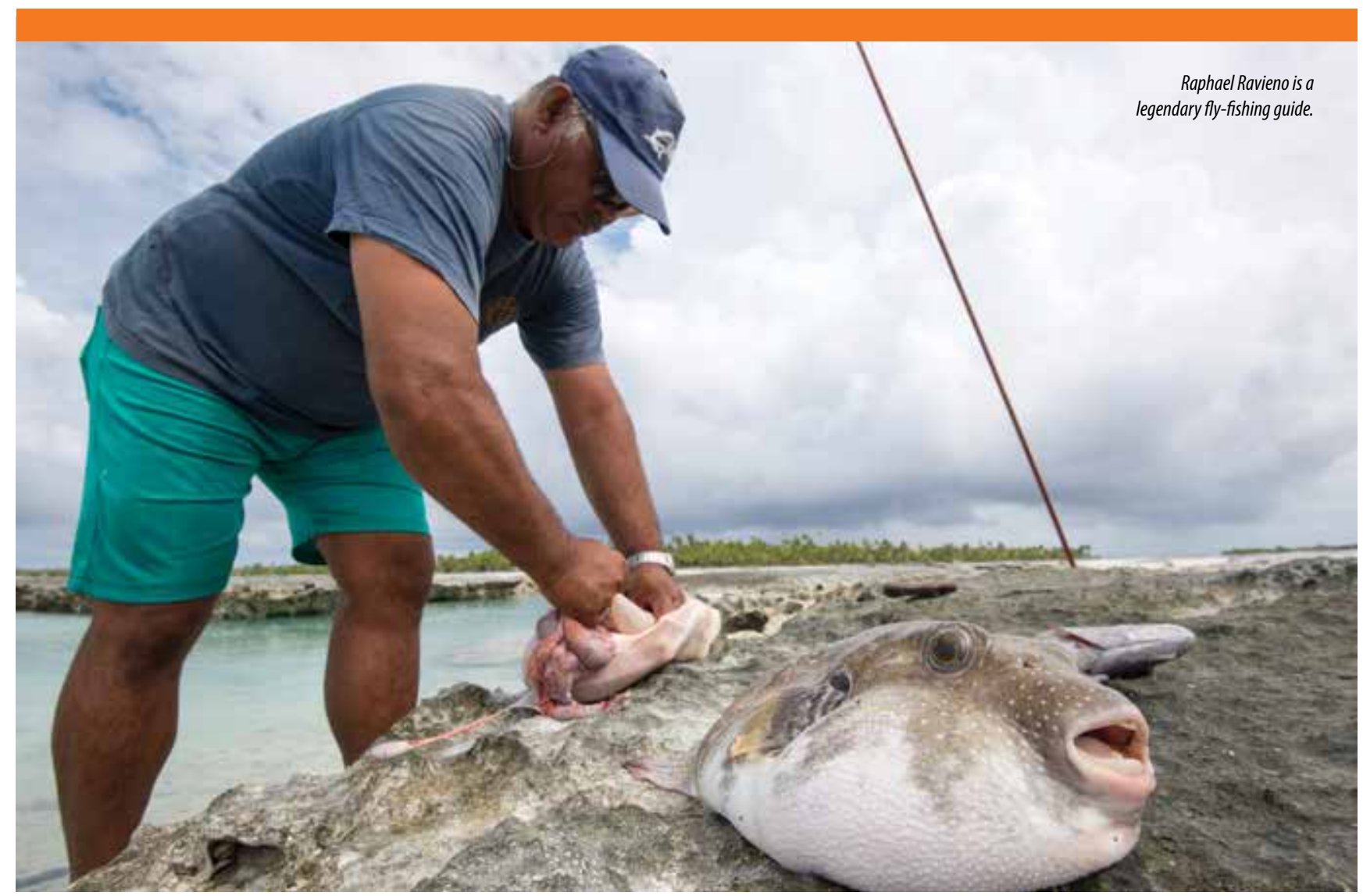

to build the johad, which is 15 feet deep and covers one acre.

Then they waited for the rains. By the end of the season, the reservoir was full. Soon water began to appear in wells that had been dry for years. Word spread, and people who had left the village began to return. "After the first johad helped the community, we have never been out of work."

Singh built the first few johads with money he had made selling his belongings when he left Jaipur. He got help from a development organization, Church's Auxiliary for Social Action, which donated truckloads of grain that he used to pay workers.

In the decades since, Singh and his organization, Tarun Bharat Sangh, have built more than 11,800 johads, helping make 1,200 villages water sufficient. Starting with a few students and professors from the University of Rajasthan, the group now has 62 full-time employees, 3,000 part-time employees, and more than 10,000 volunteers. His son, Maulik, is the group's director.

Recharging underground water aquifers also helps mitigate climate change by restoring the growth of trees in drought-stricken regions. Singh's current project is to adapt to climate change through water management. This project is being undertaken in 30 villages in a district of Rajasthan where the majority of people belong to the most marginalized and poorest communities.

Singh has a long record of activism. In the 1990s, he organized a demonstration calling for protection of rivers and mountains, leading marchers on an 800-kilometer trek from Jaipur to Gangotri, a town in the Himalayas at the source of the Ganges River. Soon after, he led a successful campaign against mining in the Aravalli Range, whose hills recharge aquifers in northwestern India and help arrest the advancing desert.

Singh says community-based efforts are more effective ways to conserve water than large infrastructure projects to pipe water to homes. "Where will the water in these pipes come from?" he asks.

"Community-based water-harvesting projects are the only way India can recharge its groundwater levels to mitigate drought," he says. "People should take ownership of their water bodies. Otherwise no conservation effort will last long."

\section{Saving the Kiokio}

It's just before noon, and Calixte Yip, mayor of the remote coral-fringed atoll of Anaa in French Polynesia's Tuamotu Archipelago, sits behind an aged wooden desk littered with items commonly found in an agricultural lab. 


\section{The island's fisherfolk are struggling with stocks that have been decimated by indiscriminate fishing practices.}

Among them are vials containing caterpillarspests that pose a major threat to the island's copra, or coconut, industry, a foundation of the atoll's economy. At the root of the problem is a warming climate that encourages the growth of pest populations and breaks down the resilience of host plants.

At the same time, the island's fisherfolk are struggling with stocks that have been decimated by indiscriminate fishing practices. These stresses are further exacerbated by limited education and employment opportunities.

But Anaa's people, the Paumotu, who were renowned in ancient times for their martial prowess, have risen to the challenge. Although the island's population plummeted from 2,000 to 500 after a devastating hurricane in the 1980 s, the remaining inhabitants continue to push back against large-scale commercial development, opting instead to live symbiotically with nature. Recently, they rejected a major developer's proposal to build a hotel on the island.

With support from the Island Initiative, a regional charity committed to sustainable development, Anaa's Paumotu are seeking to improve the island's food security by taking only what is needed from the ocean and at the right times. They have established a protected marine educational area and are retraining the people who fish the region to offer a sustainable catch-and-release fly-fishing tourism industry.

At the heart of this project is Raphael Ravieno, a guide whose legendary expertise has helped turn the island's clear, shallow lagoon into a fly-fishing mecca. Enthusiasts from around the world come to stalk triggerfish, trevally, and most important, the island's famous bonefish, known locally as kiokio.

"Everyone wants to fish with Raphael," says US-based fisheries biologist Alex Filous, who has been educating the island's children and teachers about the value of conservation and sustainable fishing.
Filous's research has been instrumental in efforts to halt the decline of kiokio stocks. He determined that the number of viable offspring produced by the spawning stock was too low to ensure a sustainable population. The reason: female kiokio were being caught in large numbers during the spawning season.

He responded by recruiting children from the local school, where Ravieno's wife works, to persuade adults to adopt conservation measures. The most important step was to restore the rāhui, a traditional ban on fishing during the kiokio's spawning season, which provided a connection to the culture of the region and has been widely embraced.

To gain support for the ban, the Island Initiative is compensating fisherfolk for the income lost during the rāhui period. It has also given local craftspeople and fly makers a guaranteed income by setting up package agreements with foreign tourism providers.

"This system is in line with ancient traditions of the Paumotu that rely on symbolic values to manage the sustainable distribution of scarce resources," says local photographer and guide Moana Kauti. "It also brings in valuable ecotourism income."

Although overfishing has undeniably played a role in the decline of Anaa's kiokio population, Ravieno says other factors are also at play. For example, the time of spawning is no longer as predictable as it once was. Climate variability is a major contributor to such seasonal biological shifts, undercutting the effectiveness of the rähui.

Challenges aside, Filous believes that Anaa is proof that an ailing small-island economy can be resuscitated by community-driven, environmentally sustainable industries. He is optimistic that tourists drawn by fly-fishing will be a major part of the solution.

"I'm confident in what is to come," he says. "This entire atoll is one giant bonefish paradise." 


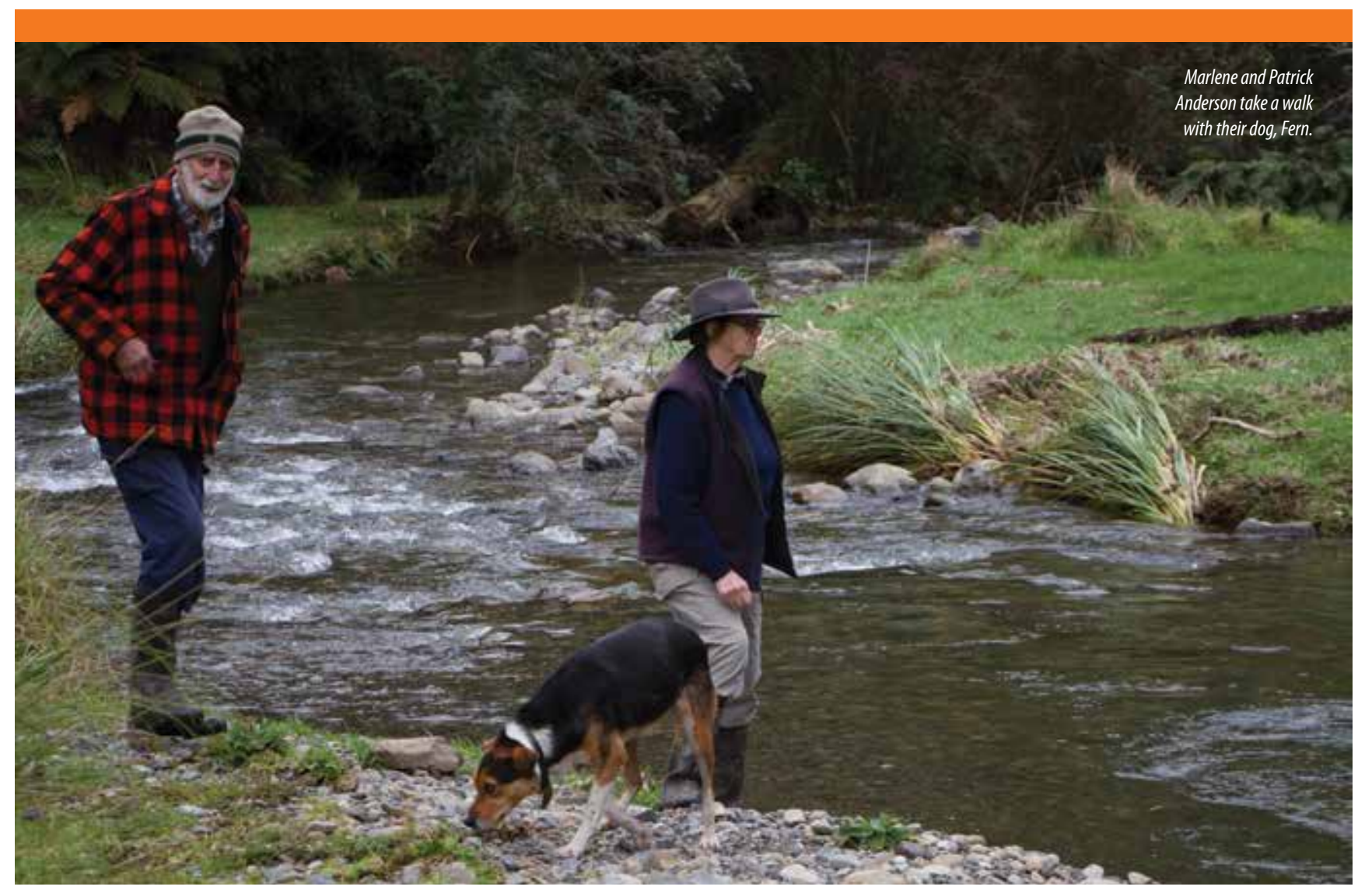

\section{From Sheep to Trees}

Three decades ago, while still in their 40s, Marlene and Patrick Anderson decided to drop out of the rat race. Since then, they have been planting trees and helping New Zealand fight climate change.

Their 884-hectare property is tucked away at the end of a long gravel road, outside a town called Shannon, about an hour and half's drive northeast of the capital, Wellington. The couple rely on satellite for their internet connection. Past their gate, there is a pretty, meandering stream that runs through an oasis filled with various species of trees and plants.

"I always wanted a stream with no one upstream," says 80-year-old Patrick.

"Back in 1987, when we bought the place, there were no trees," he says. "The land had been cleared and was used for sheep farming." Since then, the Andersons have planted tirelessly and have helped bring back native trees.

"Our ultimate aim is to return it to native forest," says Patrick. "A lot of that reversion does happen on its own. We nurture the process."

Patrick used to be an engineer with Honeywell International, a giant US-based conglomerate, working in the management of heating, ventilation, and air-conditioning systems. His wife stayed home, raising their three children.
When he turned 48 , he decided it was time for a change.

"I thought, 'I've had it with the rat race," he says. "We had to find something different to do."

Their children were 8,11 , and 14 when the family moved. They sold their house in Wellington and bought land from a local farmer.

"The owner took us in an old Toyota to a vantage point. We knew instinctively this was it," says Patrick.

Though Patrick had grown up on a farm, he knew nothing about farming. But he has always enjoyed gardening, like his father before him. Marlene's family were market gardeners. So there was an appreciation for the outdoors and for nature, but no hands-on experience.

"We thought we could develop it into a viable farm," says Marlene, who is originally from Australia. "For 14 years, we tried sheep farming. It was hard. From 2001 onwards, we leased the land out to other farmers for grazing to generate income."

In 2007, then-Prime Minister Helen Clark introduced an emission-trading system to tackle climate change. In 2008, forestry was included in the program, giving landowners an opportunity to generate revenue from the carbon dioxide sucked out of the atmosphere by trees planted since 1989. 


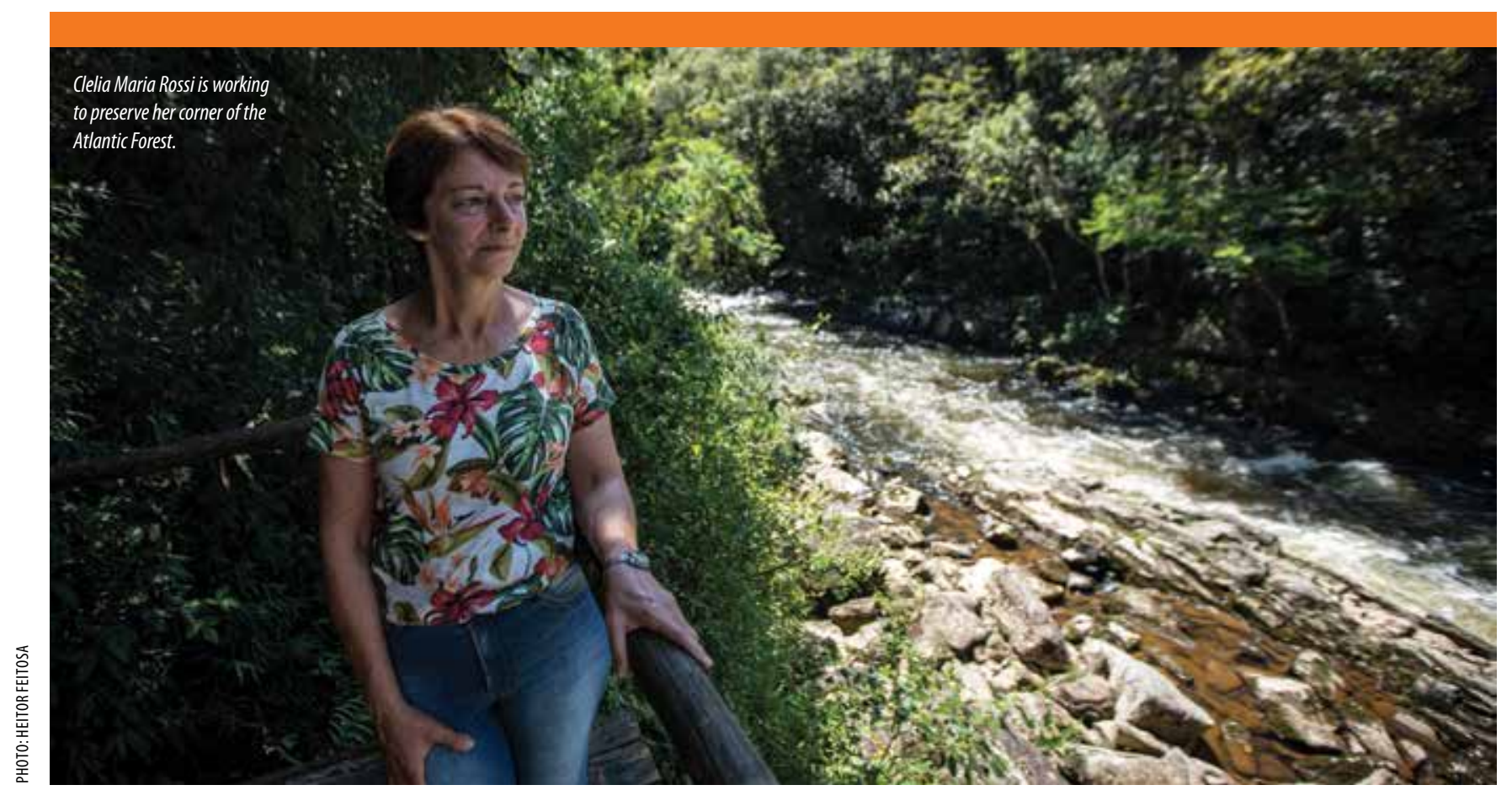

The couple realized that growing trees offered a more profitable use of their land than grazing sheep. But money wasn't their only motivation.

"Patrick loves trees. He talks to them," Marlene says.

"If we wanted to make money, we would only plant pine. We're using the credits to help regenerate the native forest." Radiata pine is the dominant plantation forestry species in New Zealand, has a very fast growth rate, and absorbs a lot of carbon dioxide.

The Andersons have a wide range of native trees on their property, including kamahi, red beech, and tawa. They have also taken steps over the years to look after their stream. In 1996, a freshwater ecologist from a nearby university came to see them.

"He was looking for streams with native fish," Marlene says. "He found lots in ours. We decided it was worth protecting. For a start, we realized it wasn't a suitable place for cattle and took the animals out of that area."

The stream is a haven for native species, which include the whitebait species of banded and shortjawed kokopu, as well as koaro, torrent fish, and red-finned bullies.

The couple have passed on their love of nature to their children.

"Our kids are tree huggers," Marlene says. Their son Luke is working on a documentary film on different ways of looking at rivers "from a spiritual and ecological point of view." David, the eldest, works for a stamp manufacturer, and Monique, who has autism, receives support to run a microenterprise that produces handmade jams, chutneys, and pickles.
The Andersons say their life journey feels fated. "If you have it deep in your head, it almost finds you, doesn't it?" Patrick says. "It was meant to be."

\section{Fighter for Forests}

Five centuries ago, the Atlantic Forest covered 1.3 million square kilometers of modern Brazil. Today, only 12 percent of that pristine paradise is left.

Clelia Maria Rossi is doing her best to preserve it.

For years, Rossi worked in São Paulo, a city of 12 million, as a volunteer for SOS Mata Atlântica, an organization dedicated to the protection of Brazil's second-largest biome after the Amazon. Over the centuries, much of the forest gave way to urban development and agriculture, including sugar and coffee plantations.

Rossi gave up her job as a high school biology teacher and left the skyscrapers of São Paulo five years ago for the small city of Juquitiba, 80 kilometers to the south. Now she is teaching children to treasure the forest that is home to 1,711 vertebrate species, 20,000 varieties of plants, and seven watersheds.

Rossi, who is divorced, moved to Juquitiba when her two daughters were grown and bought six hectares of native forest. The property was part of a larger parcel that was at risk of being cut down to make way for weekend homes with swimming pools and tennis courts.

"My dream was to buy the whole property because it is a preserved area that protects the State Park of Jurupará, and it is connected to the 


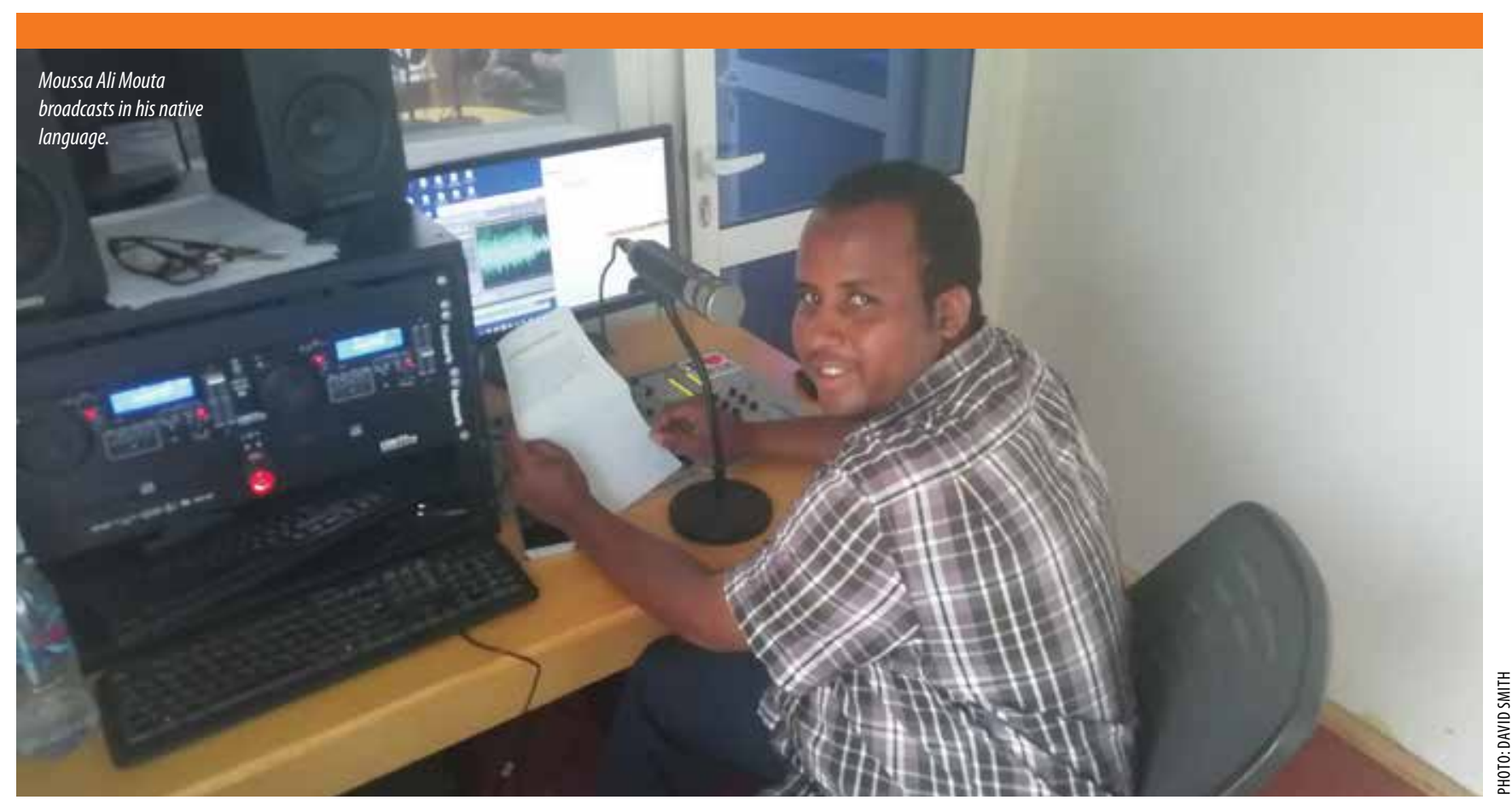

Juquiá River's riparian forests," she says. "I still don't have the money, but one day I will."

Her land is home to howler monkeys, tamarins, tree frogs, tapirs, and capybaras; there are no people, buildings, tools, or even footprints. To fence her property, she used old fire hoses rather than barbed wire, so as not to hurt the migrant animals.

"I was so happy when I first found some traces of the presence of tapirs in my land," she says. From the beginning, she knew she would have to work hard to educate the local people and build support for the protection of the remaining Atlantic Forest and the two rivers of this region of southwestern Brazil-the Juquitiba and the Juquiá.

She started teaching people who lived close to her property, especially children, the importance of the native woods. Later, she began to work in small rural communities and public schools in the city of Juquitiba. She joined a citizens group engaged in protecting local water sources that successfully stopped plans to divert the Juquiá River.

In the public schools of Juquitiba and the neighboring town of São Lourenço da Serra, Rossi finds a way to advance her cause. Every year more schools invite her to teach classes and seminars.

Rossi designs recreational activities and competitions to teach children about the separation and treatment of garbage, cleaning river banks, planting native seedlings, and ways to prepare the ground for crops without burning the land.

She teaches children to respect the remaining Atlantic Forest reserves, rivers, and sources of clean water. As she likes to say, people who learn to love nature as children will grow up to be environmentally friendly adults.

Years ago, when she graduated from university with a degree in biology, she wanted to be a researcher but could only find work as a teacher, she recalls.

"Now I already have couples who were my students whose children are coming to my programs," she says. "Being an environmental teacher is the accomplishment of my life."

\section{A Voice for Lake Chad}

When Moussa Ali Mouta told his parents he was broadcasting news to residents of central Africa's Lake Chad region in the family's native language, they cried tears of joy.

Until the launch of Radio Ndarason Internationale (RNI) in 2016, no single station targeted Lake Chad, one of the most dangerous, conflict-ridden, and environmentally distressed places on earth. Residents relied on shortwave foreign-language broadcasts by stations like the BBC and Radio France Internationale.

Moussa speaks Kanembu, one of three languages in the region, many of whose residents either have been victims of the extremist group Boko Haram or are members of the organization.

Boko Haram operates in a largely lawless area that includes parts of Cameroon, Chad, Niger, and Nigeria. A multinational task force formed to destroy Boko Haram is often the only government presence around the lake. 


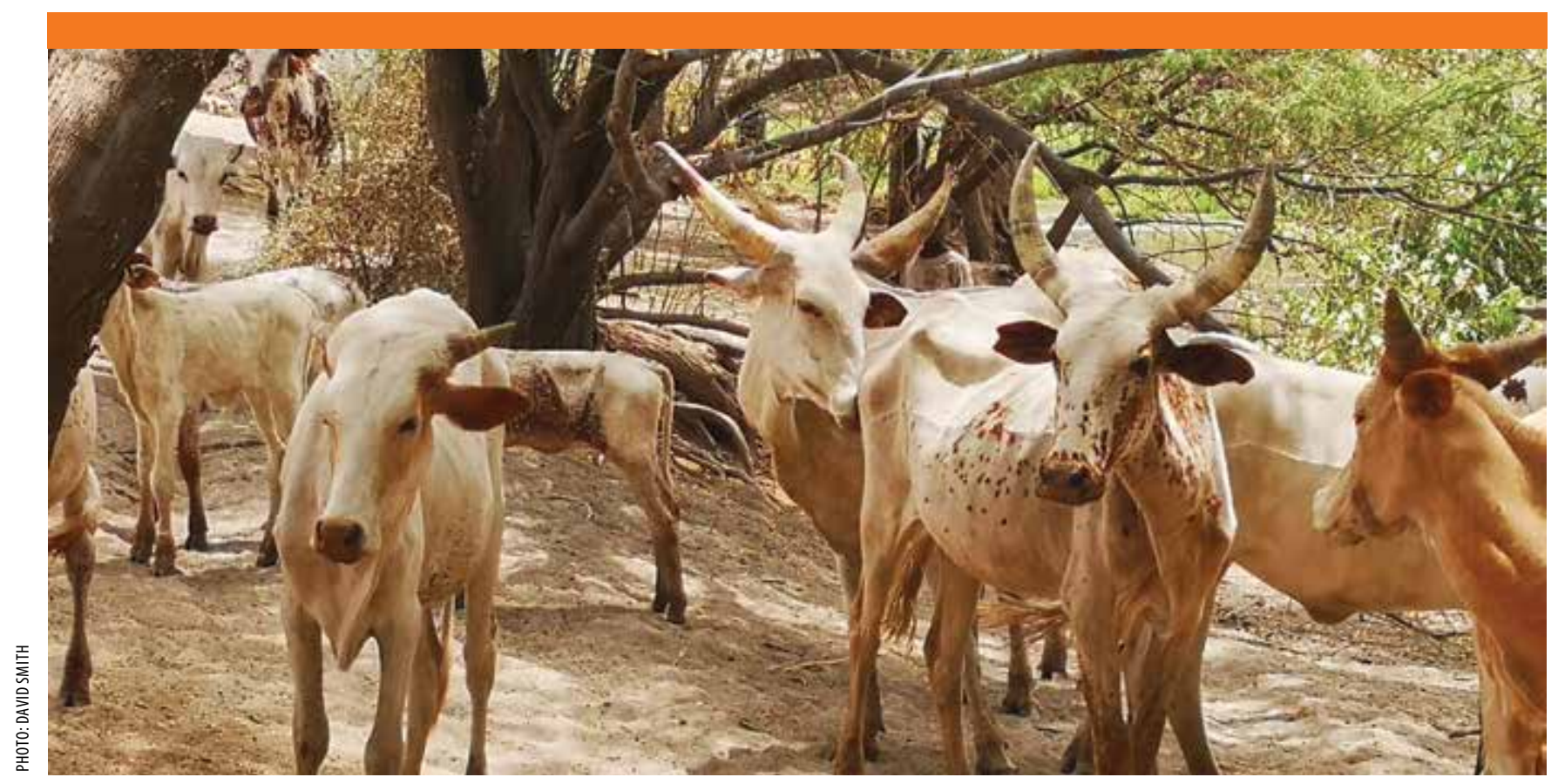

Kouri cows, found only at Lake Chad, have webbed hooves that help them swim.
The area's illiteracy, population growth, and unemployment are among the world's highest. An encroaching Sahara Desert, rising temperatures, and diminishing rainfall are shrinking a lake that provides a livelihood for tens of millions of people.

Such an environment is an ideal incubator for violence and instability, which makes it that much harder to address the problems of climate, development, health, and education.

Unusually for someone from such a poor region, Mouta was able to study communications and English in Malaysia. Few of his compatriots have been exposed to life beyond the shores of Lake Chad.

Mouta says he joined the station because he wanted to combat the region's multiple problems head-on by engaging the population, using local knowledge to forge grassroots solutions.

$\mathrm{He}$ is teaching new Kanembu colleagues to share best practices for fishing, agriculture, and pastoralism. He is in constant contact with his target audience - by telephone and social media and through work in the field. For example, he interviews a fisherman working in the Chadian waters of the lake and shares this knowledge with listeners.

RNI began operating in Maiduguri in Nigeria and N'Djamena in Chad. It has about 50 mainly Nigerian and Chadian staff and correspondents in Cameroon and Niger. The station works in partnership with the Lake Chad Basin Commission and with the political support of the African Union.

Since starting at RNI in 2016, Mouta has brought agricultural specialists, veterinarians, and experts from United Nations humanitarian agencies into the studio to supplement the knowledge he gathers in the field.

RNI devotes programming to humanitarian partners who want to reach the local population effectively, in a language they understand. Mouta notes that this is a change for the agencies, which are not accustomed to taking advantage of a regional -radio approach.

Mouta, who is 29 years old, is a natural behind the microphone, throwing out admonitions in Kanembu in an effort to prompt people to think regionally rather than locally - phrases such as "taking care of our environment is taking care of our future, including the future of our children."

Because of weak infrastructure and instability, shortwave radio remains a key source of news for the population of the lake region. Transmitters are located off the Atlantic coast, protecting them from attack.

With buy-in from the region's four national governments and the support of the Netherlands, the United Kingdom, and other donors, radio is being used as a tool to stimulate dialogue among the primary victims of instability and the worsening climate crisis. If the goal is a stable, prosperous, and sustainable Lake Chad region, the people of the lake must believe it is possible. Mouta is proof they do. FD

Reported by ASHLIN MATHEW in New Delhi, India;

DAPHNE EWING-CHOW in French Polynesia; ANNA JAQUIERY in Wellington, New Zealand; DENISE MARÍN in São Paulo, Brazil; and DAVID SMITH in N'Djamena, Chad. 


\section{IMF PUBLICATIONS}

AT NO CHARGE。 FREE

ACCESS TO OUR

E-COLLE CTION

O F MORE THAN

21,000 T I T L E S

\section{STARTING JANUARY 1, 2020.}

\section{VISIT ELIBRARY.IMF.ORG}

\section{B E CA US E KNOWLED G E $\begin{array}{lllllllllllll}\text { I S } & A & \text { P } & \text { U B } & \text { B } & \text { I } & \text { C } & \text { G } & \text { O } & \text { O } & \text { D }\end{array}$}

I N T E R N A T I O NA L M O N E T A R Y F U N D 


\section{PEOPLE IN ECONOMICS}

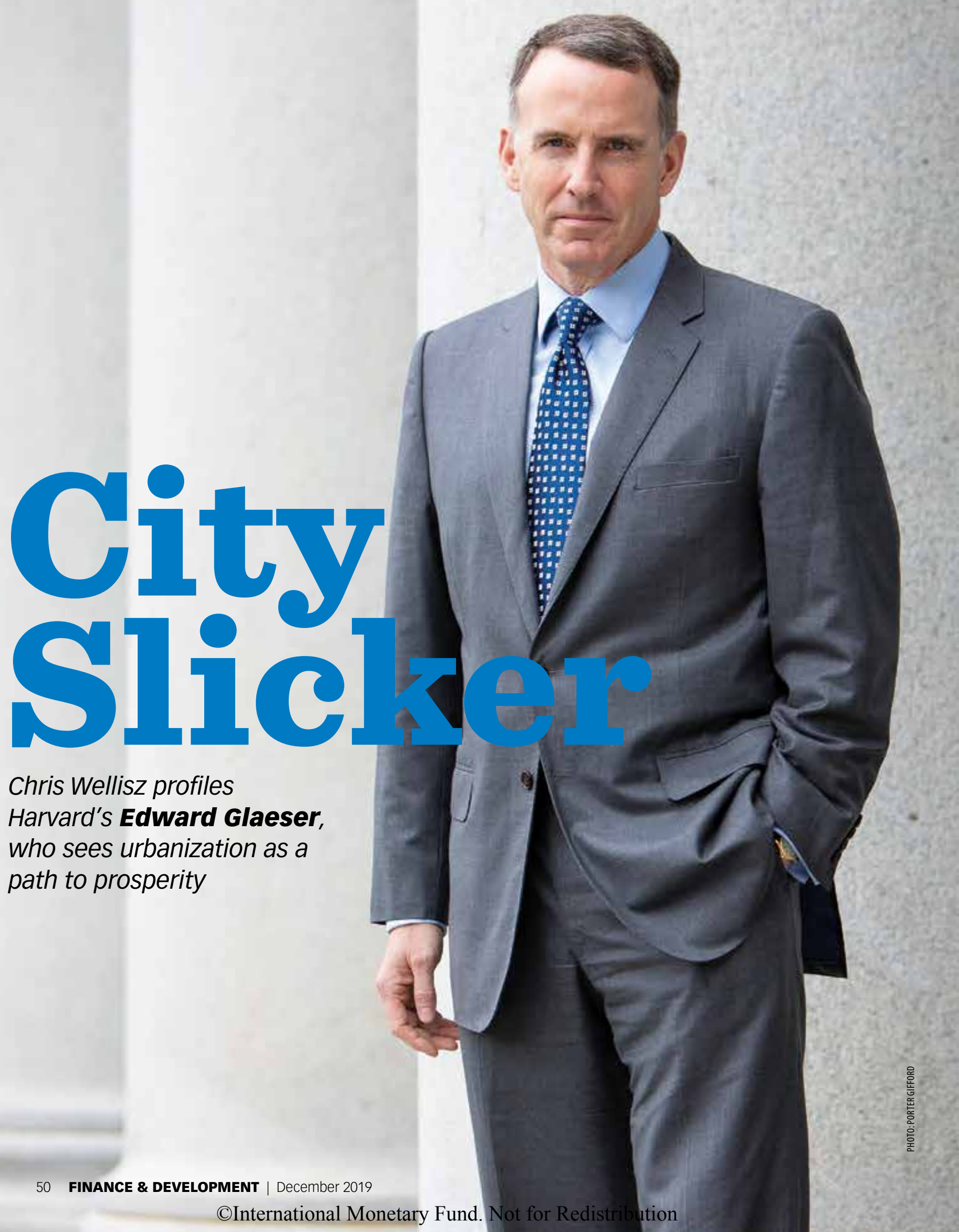




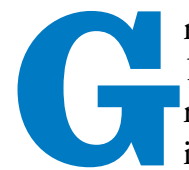
rowing up in New York City in the 1970s, Edward Glaeser saw a great metropolis in decline. Crime was soaring. Garbage piled up on sidewalks as striking sanitation workers walked off the job. The city teetered on the edge of bankruptcy.

By the mid-1980s, it was clear that New York would bounce back. But it could still be a scary place; there was a triple homicide across the street from his school on the Upper West Side of Manhattan. Glaeser was nevertheless captivated by New York's bustling street life and spent hours roaming its neighborhoods.

"It was both wonderful and terrifying, and it was hard not to be obsessed by it," Glaeser recalls in an interview at his office at Harvard University.

Today, that sense of wonder still permeates Glaeser's work as an urban economist. He deploys the economist's theoretical tool kit to explore questions inspired by his youth in New York. Why do some cities fail while others flourish? What accounts for sky-high housing costs in San Francisco? How does the growth of cities differ in rich and poor countries?

"I have always thought of myself as fundamentally a curious child," Glaeser, 52, says. Rather than "pushing well-established literature forward," he seeks to comprehend "something that I really don't understand when I start out."

While still a graduate student at the University of Chicago, Glaeser made his mark as a theorist of the benefits of agglomeration - the idea that dense and diverse cities are hothouses of innovation, energy, and creativity that fuel economic growth. In the years since, his work has ranged across a breathtaking variety of subjects, from rent control and real estate bubbles to property rights, civil disobedience, and carbon emissions.

"For a couple decades now, Ed has been the leading thinker about the economics of place," says Lawrence Summers, a Harvard professor who served as director of the National Economic Council under US President Barack Obama. "And the economics of urban areas are increasingly being seen as central to broad economic concerns."

Glaeser and Summers are collaborating on a study of the hardening divide between welleducated, affluent coastal regions of the United States and islands of economic stagnation in what they call the "eastern heartland," the interior states east of the Mississippi River. There, in cities like
Flint, Michigan, the proportion of prime-age men who aren't working has been rising_-along with rates of opioid addiction, disability, and mortality.

How can policy help? Traditionally, economists have been skeptical of the value of place-based policies like enterprise zones that offer tax breaks to investors, saying it is better to help people, not places. People, they assumed, would move to where the jobs were. But labor mobility has declined in recent decades, partly because of high housing costs, partly because demand for relatively unskilled factory work has diminished.

Breaking with economic orthodoxy, Glaeser and Summers say that the federal government should tailor proemployment measures, such as reducing the payroll tax or increasing tax credits to low earners, to fit the needs of economically distressed areas such as West Virginia. They also make the case for boosting investment in education.

As a Chicago-trained economist, Glaeser is a strong believer in the magic of free markets and opposes measures that distort incentives. "I have always been against spatial redistribution, taking from rich areas and giving to poor areas," he says. "That doesn't mean that you want the same policies everywhere."

Urban economics seemed like a natural pursuit for Glaeser. His German-born father, Ludwig, was an architect who taught him how the built environment shapes people's lives. His mother, Elizabeth, was an asset manager who introduced him to economics. Glaeser recalls how she used the example of competing cobblers to explain marginal cost pricing.

"I remember thinking what an amazing and fascinating thing it is to think about the impact of competition," he says. He was 10 years old.

In high school, Glaeser excelled at history and mathematics. As a Princeton University undergraduate, he considered majoring in political science before choosing economics, seeing it as a path to Wall Street. But dreams of a career in finance ended with the stock market crash of 1987, just as he started job interviews. So he opted for graduate school, because "it didn't seem like I was cutting off many options," he says.

"Then I got to Chicago, and that was when I really fell in love with economics."

Glaeser keeps a framed photograph of himself with Gary Becker, the Chicago economist and Nobel prize laureate. Becker taught him that the discipline's conceptual tools could be used to 


\section{Cities thrive on the creativity that occurs when people living cheek by jowl exchange ideas and know-how.}

explore topics that had once been the domain of fields like sociology or anthropology-topics like racial discrimination, fertility, and the family.

"It was that sense of the creative side of economics that could work on a virtually unlimited canvas and try to make sense of any problem that you thought was important- that was the part that was so exciting to me," Glaeser says.

At the time, Chicago economists Robert Lucas and Paul Romer were developing the so-called endogenous growth theory, which focused on the role of innovation and the exchange of ideas in economic development.

As Glaeser recalls it, Lucas pointed to cities as places where knowledge spillovers occur-meaning people can benefit from other people's ideas without paying for them. Think of a city like Detroit early last century, where Henry Ford used his experience as chief engineer at the Edison Illuminating Company to start his automobile business.

That concept inspired a groundbreaking 1992 paper, "Growth in Cities." Glaeser and three coauthors set out to use cities as a laboratory in which to test the new growth theories. Using 30 years of data covering 170 US cities, they found that local competition and diversity, rather than specialization, are the prime motors of urban growth.

The paper instantly made Glaeser a star and earned him a job offer from Harvard.

Glaeser "showed that urban variety, not specialization in one particular thing, was a big driver of employment growth," says Joseph Gyourko, a professor at the University of Pennsylvania's Wharton School and a longtime collaborator. "It was Ed's first really well-cited article, so it did start him on his path."

Gyourko and Glaeser started working together in the early 2000s, when Glaeser took a year's sabbatical at Penn. They wondered why some cities, such as Detroit, declined so slowly, and why so many people stayed instead of moving elsewhere. They hit upon a simple answer: housing is durable, and as cities slump, it becomes cheaper to live there.

That insight prompted a related question: Why is housing so much more expensive than the cost of construction in cities like New York and Boston? The answer: land-use restrictions limit density, curbing the supply of housing and driving up prices. It was basic economics, yet until then, urban economists hadn't focused on the role of regulation.

Glaeser argues that excessive regulation is destructive of the very essence of urban lifedensity. Cities thrive on the creativity that occurs when people living cheek by jowl exchange ideas and know-how. Sunbelt cities like Houston have grown because an easy regulatory environment keeps housing inexpensive.

To economists like Glaeser, building and zoning regulations are a tax on development. Some level of tax makes economic sense, because construction imposes costs on residents in the form of noise, congestion, and pollution. But overly stringent regulation, often pushed by residents who want to keep out newcomers and protect their property values, can make housing unaffordable for most people.

Glaeser is similarly skeptical of historic preservation rules, to the dismay of followers of Jane Jacobs, the legendary critic of urban-renewal projects who celebrated the lively street life of New York's old ethnic neighborhoods. Glaeser is a big Jacobs fanhe owns an autographed copy of her 1961 classic, The Death and Life of Great American Cities-but argues that her efforts to oppose development in Greenwich Village were at odds with her support for low-income housing.

"I believe that many of our oldest buildings are treasures," he says. "But don't simultaneously pretend that that's a route toward affordability. Affordability is created by mass-produced cheap housing or mass-produced cheap commercial space. And you might not like it aesthetically, but that is the affordable route."

In 2000, Glaeser published "Consumer City," a paper he wrote with Jed Kolko and Albert Saiz. In it, he took the concept of agglomeration a step further, arguing that people are drawn not only to the opportunities that cities offer, but also to amenities such as theaters, museums, and restaurants.

"We know that cities can attract the disproportionately young and innovative," says Richard 
Florida, a professor of urban studies at the University of Toronto. "Ed was identifying the factors driving that, this whole idea that cities are not only places of production, but places of consumption."

Glaeser laments policies such as the mortgage interest deduction, which encourages people to buy homes rather than rent apartments; highway subsidies, which make it easier to drive to the suburbs; and a school system that disadvantages inner-city students. Such policies, he argues, not only are antiurban but also contribute to climate change, because city dwellers, who live in smaller homes and use mass transit, consume less electricity and gasoline than their suburban counterparts.

Surprisingly, he and his wife, Nancy, who have three children, decided to move to the suburbs of Boston several years ago. To Glaeser, it was a perfectly rational decision: the suburbs offer more living space, better schools, and a reasonably fast commute.

Already well known in academia, Glaeser started to reach a broader audience with the publication in 2011 of his bestselling book, Triumph of the City, a lively study of urbanization from ancient Baghdad to modern Bangalore. His eloquence and enthusiasm make him a sought-after speaker at academic forums and TED Talks. Invariably, he is impeccably attired in well-pressed suits and preaches the gospel of urbanization in crisp, rapid -fire sentences.

Despite his celebrity, he takes teaching seriously. Rebecca Diamond, who attended his advising sessions as a graduate student, said he was generous with his time. "He taught me perspective and not to get too stuck in the weeds," says Diamond, who now teaches at Stanford University and stays in touch with Glaeser.

Developing-world cities are his latest passion. True to form, he sees them as relatively uncharted territory, neglected both by urban economists, who focus on advanced-economy cities, and development economists, who concentrate on rural areas. They are also growing fast, and their physical and institutional infrastructure are works in progress, so economists' policy advice can have an impact.

"The ability of economists to make a difference by getting engaged is just very large," he says. "So I think it is the new frontier."

It also takes him to interesting places. His latest research project, with Nava Ashraf and Alexia Delfino of the London School of Economics, took him to the markets of Lusaka, Zambia, to study

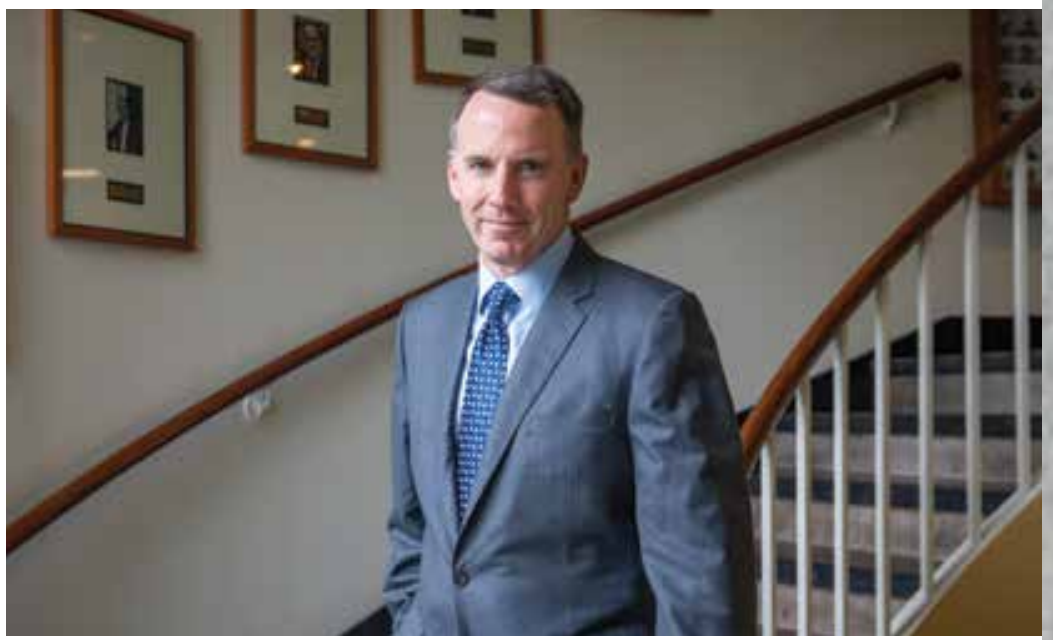

barriers to female entrepreneurship. They found women are more likely to go into business if the rule of law is strong enough to help overcome inherently unequal relations with men.

Like Jane Jacobs, Glaeser is big believer in observing what he sees around him. "You don't really understand a city until you've actually walked in the streets," Glaeser says.

"That's what makes Ed a first rate applied theorist," says Gyourko. "You've got to get your hands messy in the data. Sometimes data is just walking around."

While researching Triumph of the City, Glaeser explored places like Mumbai's Dharavi quarter, which was a "completely magical experience." Among the world's most densely populated places, Dharavi hums with entrepreneurial energy, with potters, tailors, and other craftsmen working side by side in cramped, ill-lit quarters.

At the same time, unpaved streets, polluted air, and open sewers are reminders of the downsides of density. But Glaeser doesn't bemoan the poverty of such places; on the contrary, he says cities attract the poor precisely because they offer opportunity. For the developing world, urbanization is the best path to prosperity.

"For all of their problems, amazing things are happening in India and sub-Saharan Africa and Latin America," Glaeser says. "And things obviously don't always go the right direction, but cities have been working miracles of collaboration for thousands of years, and whenever I go to a developing-world city, it is obvious to me that the age of miracles is not over." FD

CHRIS WELLISZ is on the staff of Finance \& Development. 


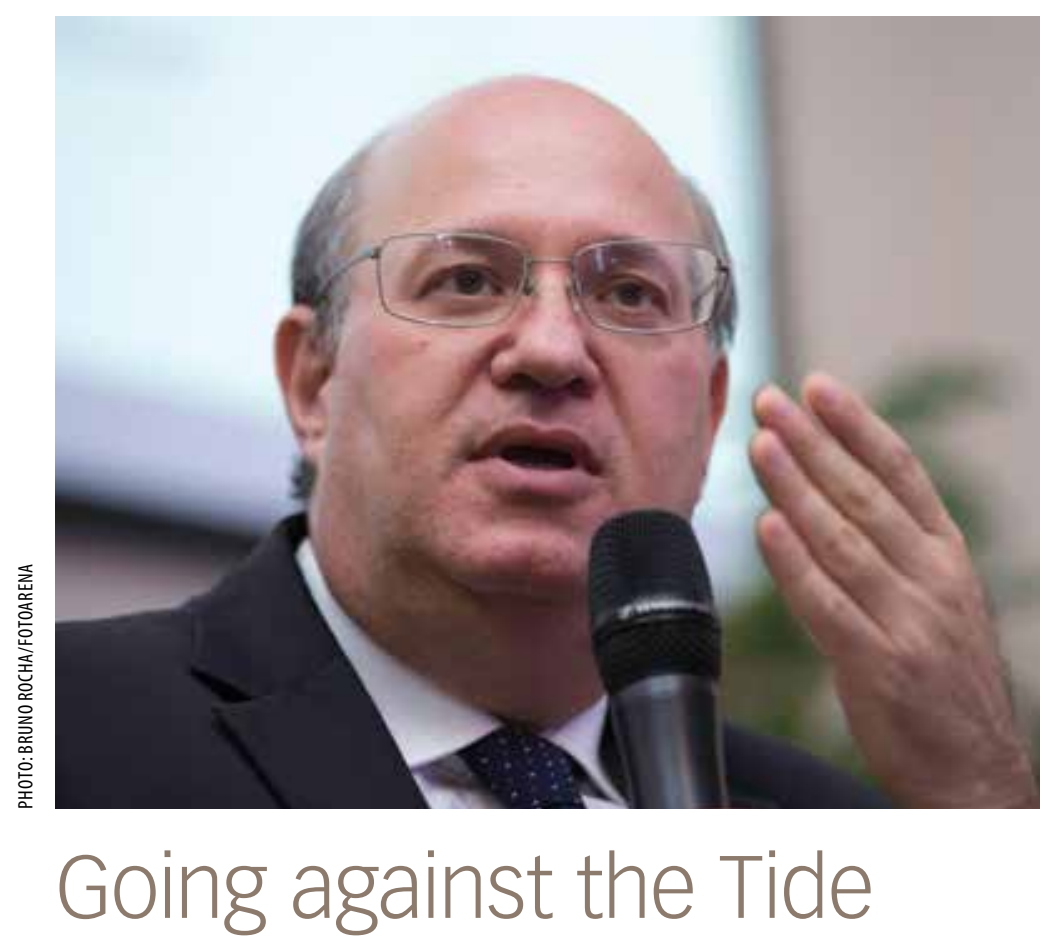

\section{Brazil's Ilan Goldfajn explains why central bankers ought to follow their convictions}

CENTRAL BANKS SHOULD NEVER surprise markets, so goes the cliché. But Ilan Goldfajn knows that sometimes that is exactly what is needed. In mid-2016, during his first two weeks as governor of Brazil's central bank, markets, journalists, and commentators all believed that the country's inflation-targeting regime would have to be adjusted, because inflation was too high. Goldfajn disagreed and stood his ground. Inflation in 2017 was 2.95 percent, a little below the tolerance margin.

Born in Israel, Goldfajn grew up in Rio de Janeiro during a time of profound economic disarray in Brazil, witnessing four currency changes in seven years and inflation upward of 80 percent a month. He earned a PhD from the Massachusetts Institute of Technology and worked with Asian countries at the IMF during the late 1990s. He was deputy governor for economic policy at Brazil's central bank in the early 2000s and chief economist of Itaú Unibanco, Brazil's largest bank, from 2009 to 2016, before returning as president of the central bank from June 2016 to February 2019. Recently named Credit Suisse's new chairman in Brazil, he spoke with F\&D's Andreas Adriano about the evolution of central bank communications in recent years and the importance of knowing when to reject the consensus view.

F\&D: How was it to challenge the entire economic establishment so early in your term? IG: Sometimes you have to have conviction and go against the consensus of markets, press, and analysts. In my first two weeks as central bank governor, in 2016, there was a public debate about whether the Brazilian economy, coming from an inflation rate of 11 percent, would be able to reach the 4.5 percent target the following year. We believed it would be difficult and challenging, but possible. There was very low demand, significantly below the economy's potential after two years of recession. It therefore seemed eminently reasonable to me that if we could coordinate expectations and change the direction of economic and monetary policy, we could reach the target. It was a wise decision: inflation in 2017 dropped to 2.95 percent, below target.

F\&D: You also broke with expectations at the end of your term.

IG: By 2018, inflation was still below target. Expectations were anchored, but interest rates were rising in the United States, driving up rates in emerging economies. So it seemed that Brazil should also raise its rates. However, with the economy recovering slowly_though still below its potential-and low inflation, our framework did not recommend raising rates. For the second time, then, both at the beginning and at the end of my term, we went against the consensus.

F\&D: In the end, it was about trusting your own regime, sticking to your own rules?

IG: Exactly. A lot of people said we were being too orthodox. But occasionally you need to have convictions based on the regime and on your own instincts to challenge consensus.

F\&D: Both cases showed a need to communicate more proactively. How did you do that?

IG: We had a major boost in transparency, changing the monetary policy decision announcement and the minutes. We tried to communicate in simpler, more concise, and straightforward language, seeking better understanding of our actions, especially what we would do, depending on what 
would happen next. Inflation expectations are very important. So, if people know what you're going to do depending on the circumstances and the fundamentals, that's the best thing.

F\&D: From Alan Greenspan's assertion that "If I'm too clear, you've probably misunderstood what I've said" to Mario Draghi's "We will do whatever it takes to save the euro," how have the perceptions of what central banks can and should communicate changed?

IG: Today, most agree that transparency is desirable. The Federal Reserve has changed: we know its targets, projections, and policy intentions. It employs increasingly direct communication to influence expectations. This is true in Europe, too. We see this not only with "whatever it takes" but also with other phrases such as "We will keep interest rates low for a long time."

In Brazil, we would warn: "We only intend to act on monetary policy if this market turbulence affects inflation expectations" or "We hope to continue our policy of monetary expansion." Central bank transparency is fitting in a new world where information is public. No one is satisfied with just knowing the decision without understanding the rationale. It used to take a long time to get minutes out. Nowadays, in Brazil, the monetary policy decision comes out on a Wednesday and the minutes on the following Tuesday morning.

F\&D: Has this changed your work as governordid you have to talk to more people, different stakeholders?

IG: Not only your words, but also your life is under scrutiny 24 hours a day. You can never afford to be a private citizen and speak your mind, even among close friends or family. Because information flows, you have to be careful about every action and respect public resources, like the driver or the plane. You must get in line and take a commercial flight like everyone else. When you're in the middle of a crisis, people will look at you and say, is he nervous or not, has he gained weight or not?

F\&D: Isn't it a surprise that at the same time central bank independence is being challenged in so many countries?

IG: In some ways, the perception that central banks are a powerful crisis-fighting tool puts pressure on them to do more. Everyone would like to see us stimulate the economy more and avoid crises and market turmoil. In advanced economies, unconventional policies were needed because the global financial crisis was unconventional, but many politicians questioned what was done.

F\&D: What challenges does a dual mandate-such as the Fed's twin goals of low and stable inflation and full employment-pose for central banking? IG: Today, central banks already worry about inflation as well as growth. They stimulate the economy when it is in recession. If inflation is below target, but there is a recession, or if inflation is on target, but there's unemployment, you stimulate it. Even when inflation is above the target, the trajectory-that is, how long it takes to converge to the target-is considered as well. Every central bank in the world takes these short-term trade-offs into account.

F\&D: So, in practice, there is already a dual mandate.

IG: Yes, but most central banks understand that longterm growth is beyond their mandate. It depends on productivity, education, investment, and other real economy factors beyond their performance. When I say the central bank takes these things into account, I mean these short-term trade-offs between inflation and other economic dimensions. It should not be confused with increasing long-term growth. The central bank contributes through stability, but more stimulus won't generate more productivity.

F\&D: Is there too much worry about exchange rate depreciation, especially in emerging market economies?

IG: When there is turmoil, there are always pressures, and the central bank and treasury must know how to deal with them. There is a role for the central bank in dealing with disorderly market conditions and helping markets function better. Apart from that, it is important to let the exchange rate fluctuate in a way that reflects the fundamentals and the shocks. Policymakers must be able to distinguish when it deserves special attention and when it should be left on its own. Every policymaker is always searching for a framework to determine when to intervene and when to allow the exchange rate to reflect the current economic reality. FD

This interview has been edited for length and clarity. 


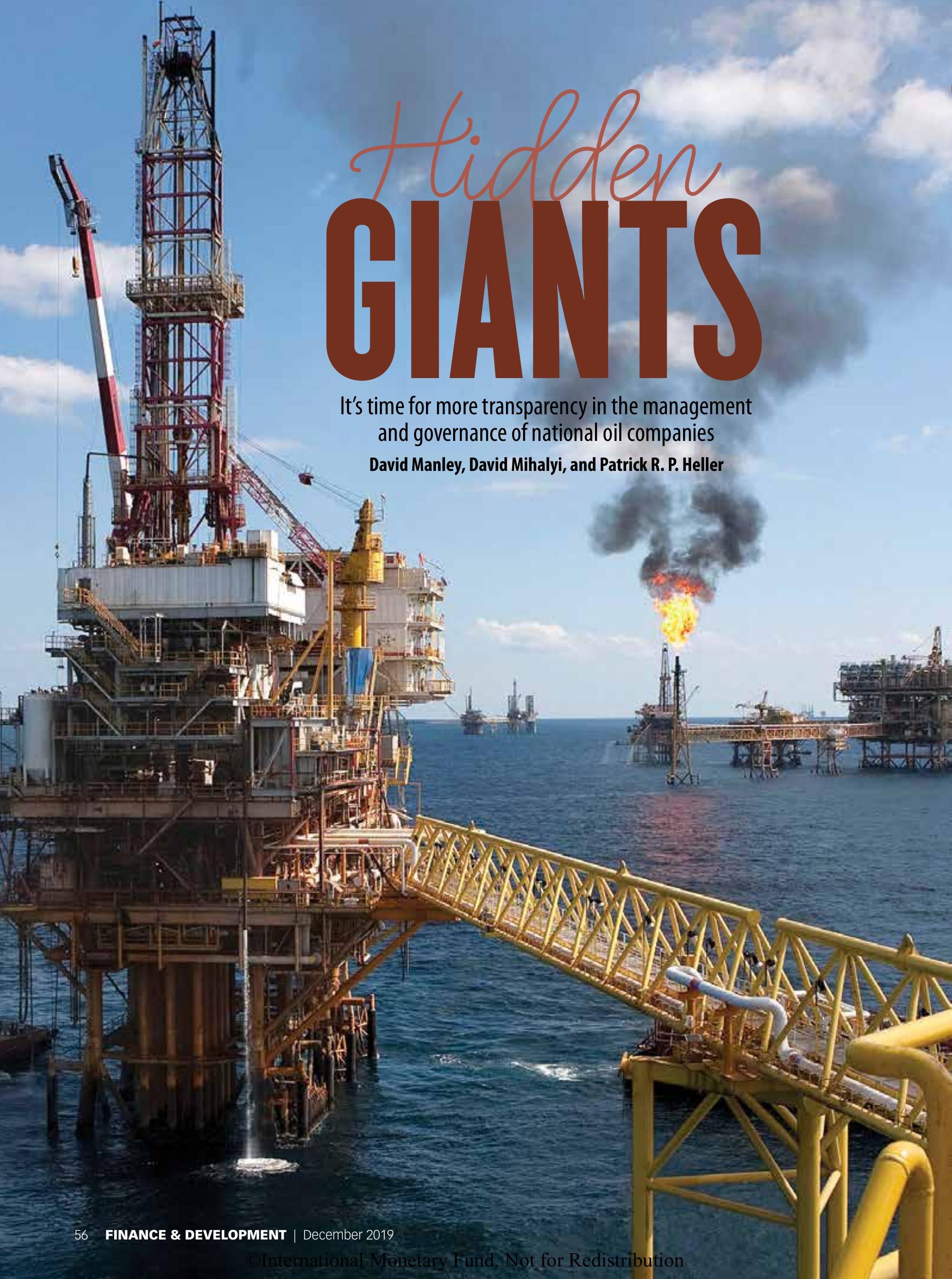


N ational oil companies (NOCs) are economic giants. They control at least $\$ 3$ trillion in assets and produce most of the world's oil and gas. They dominate energy production in some of the world's most oil-rich countries, including the Islamic Republic of Iran, Mexico, Saudi Arabia, and Venezuela, and they play a central role in the oil and gas sector in many emerging producers.

NOCs are poorly understood because of their uneven financial reporting practices, and NOC governance has often been treated as a niche issue in public finance literature. A new report and accompanying database from the Natural Resource Governance Institute focus on the failure to rigorously scrutinize NOCs and the policies their governments employ to manage them, and how this failure carries major risks for dozens of economies around the world that depend on these companies' sound management of public resources.

\section{Limited transparency}

Many NOCs remain opaque. For the most data-rich year covered by the National Oil Company Database, only 20 of the 71 NOCs we studied published information sufficient to populate all 10 of the database's "key indicators." Information on production and revenue is available for most NOCs, but less than half of those we studied reported on capital expenditure or employment. On average, NOCs in the Middle East and sub-Saharan Africa disclosed the least amount of information. These findings reinforce the results of the institute's Resource Governance Index, which revealed that 62 percent of the NOCs reviewed exhibited "weak," "poor," or "failing" performance in regard to public transparency.

Because the companies are so large, shortcomings in their reporting pose several economic risks. At the peak of the oil price boom in 2013, there were at least 25 "NOC-dependent" countries - those where the NOC collects funds equivalent to 20 percent or more of government revenues (Chart 1). In most cases only a fraction of these resource revenues are then transferred to the governments, with the NOCs spending and investing the rest themselves. The median NOC in our sample transferred only 17 percent of its gross revenues to the state in 2015.

While NOCs are generally a substantial source of government revenue, especially in boom times, many also take on large amounts of debt. They borrow to finance new investments, meet political agendas, or maintain sizable discretionary expenditures.
NOC borrowing may take the form of loans from banks (for example, the Ghana National Petroleum Corporation), oil-backed loans from other NOCs or traders (for example, Kazakhstan's KazMunayGas), loans from another government entity (Algeria's Sonatrach borrows from the country's central bank), or issuance of corporate bonds (Russia's Rosneft).

Excessive debt can also create significant risks. A handful of NOCs have been carrying very large amounts of debt, including Petróleos de Venezuela, S.A., and Angola's Sonangol - their debts exceed 20 percent of those countries' GDP. Some NOCs are highly leveraged, such as Rosneft and the United Arab Emirates' TAQA. But maintaining a healthy balance of debt to equity is not always enough to minimize risk. Petróleos de Venezuela is currently unable to service part of its $\$ 35$ billion in debt, even though it holds much larger assets through equity. Its 335 billion barrels of oil-equivalent reserves are mostly locked underground, and the company is unable to access them amid falling production and the combined impact of an economic crisis and sanctions. In the long term, avoiding large-scale default is central to any efforts to emerge from the current crisis. Mexico's Pemex, as another example, had more than $\$ 100$ billion in debt on its balance sheet by the end of 2018, forcing the Mexican government to dip into public coffers this year to bail the company out.

In a country where the dominant NOC is essentially too big to fail, the government may ultimately be on the hook for debts the NOC has incurred, even when they are not formally guaranteed by the state. These debts are also treated inconsistently in public reporting. Public debt figures for Mexico and Venezuela include the debts of their NOCs, for example, but NOC debts are not included in national debt for Bolivia or Brazil. Moreover, our database also shows important weaknesses in public reporting. In 2013, at a time of peak commodity prices, companies responsible for 57 percent of global NOC oil and gas production did not publish independently audited financial statements.

\section{NOCs and society}

In practice, the term "national oil company" encompasses a wide range of entities with varying roles. Some are profit seekers that prioritize commercial efficiency. Others are cash cows, focused on collecting revenues from private companies that undertake most of the operations. "State supplement NOCs" perform a wide range of public functions, including providing fuel subsidies, creating jobs, and providing social services. 
Chart 1

\section{The risk of dependence}

At the peak of the oil price boom, there were at least 25 "NOC-dependent" countries — where the national oil company collected funds equivalent to 20 percent or more of government revenues.

(National oil companies' total revenues as a percentage of general government revenues, 2013)

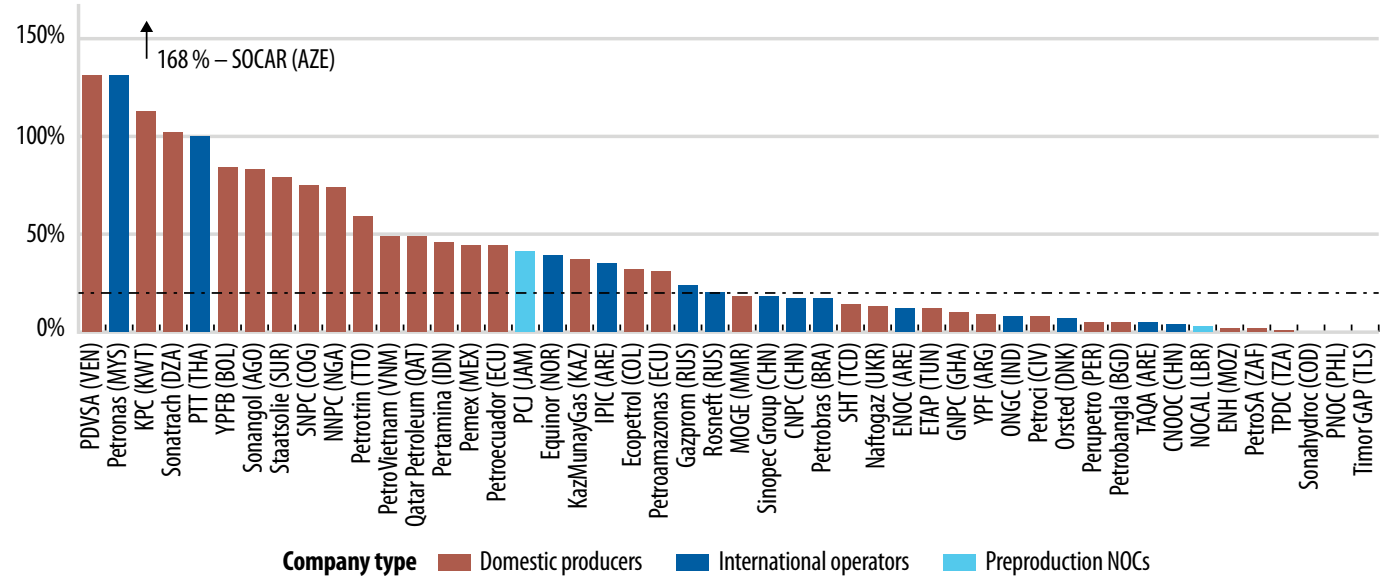

Source: Heller and Mihalyi, 2019, Massive and Misunderstood Data-Driven Insights into National Oil Companies. NRGI.

Note: Data labels in the chart use International Organization for Standardization (ISO) country codes. NOC = national oil company.

These categories belie the complex mandates of NOCs, many of which play multiple roles simultaneously.

Our data provide clues for mapping the roles different companies play and how well they achieve their various objectives. Building on earlier work by Nadejda Victor (2007), Chart 2 shows the productivity of labor in production terms (production per employee) and total employment figures (logged) for the NOCs in our sample for which data are available. On average, the larger the labor force, the less productive that labor force is in purely commercial terms. In addition, companies that list shares on a public stock exchange exhibit higher production per employee than unlisted counterparts of similar size. This discipline may be the result of shareholder pressure to maximize returns per employee or because listed NOCs are more likely to be profit seekers focused on commercial activities.

Many of the companies that show low levels of labor productivity are companies that undertake greater state supplement roles. For example, Ukraine's Naftogaz plays a significant downstream state supplement role, and the Ukrainian government has required it to furnish energy to citizens at subsidized rates.

\section{A renewable future?}

With the global drive to transition away from fossil fuels, NOCs from Colombia to Nigeria to Saudi Arabia have started pivoting toward renewable energy investments. Some NOCs could indeed lead their countries' energy transitions. In many countries, NOCs employ some of the best-educated professionals and bring experience managing complicated projects with international partners. They are already integrated into the intricate set of systems that supply fuel and power. In a sense, NOCs may seem like a natural fit to drive an expansion of wind, solar, and other renewable energies.

But there are also reasons for skepticism that most NOCs will be able to transform into advocates of renewable energy. As our database reveals, selling oil and gas is still the dominant way these companies make money. In 2015, the median NOC in our sample relied on oil and gas sales for 96 percent of its total revenues. The size of the rents available in fossil fuels, the bespoke skills and technologies involved in the sector, and the entrenched political interests associated with oil all pose obstacles to NOC efforts to transform.

A parallel implication of energy transition is that it may increase the risks associated with NOC expenditures on oil exploration and production. Many countries have channeled a large share of their national wealth into their national oil companies. NOCs in Azerbaijan, Bolivia, Kuwait, Qatar, and Venezuela control more than 2.5 percent of total national wealth, a measure that combines produced capital, natural capital, human capital, and net foreign assets. And as noted earlier, many NOCs spend most of the money they collect. This approach has always come with opportunity costs. The company spends significant amounts of revenue instead of transferring it to the treasury for public sector investments, with the goal of accumulating assets and capturing a bigger share of the country's petroleum revenues.

The resulting concentration of wealth has always alarmed economists, who don't like to see countries put all their eggs in one basket. But the risk to 


\section{Inverse relationship}

On average, the larger a national oil company's labor force, the less productive that labor force is in purely commercial terms. In addition, publicly listed national oil companies also exhibit higher production per employee than similarly sized unlisted counterparts.

(Oil and gas production per employee, 2011-17 average)

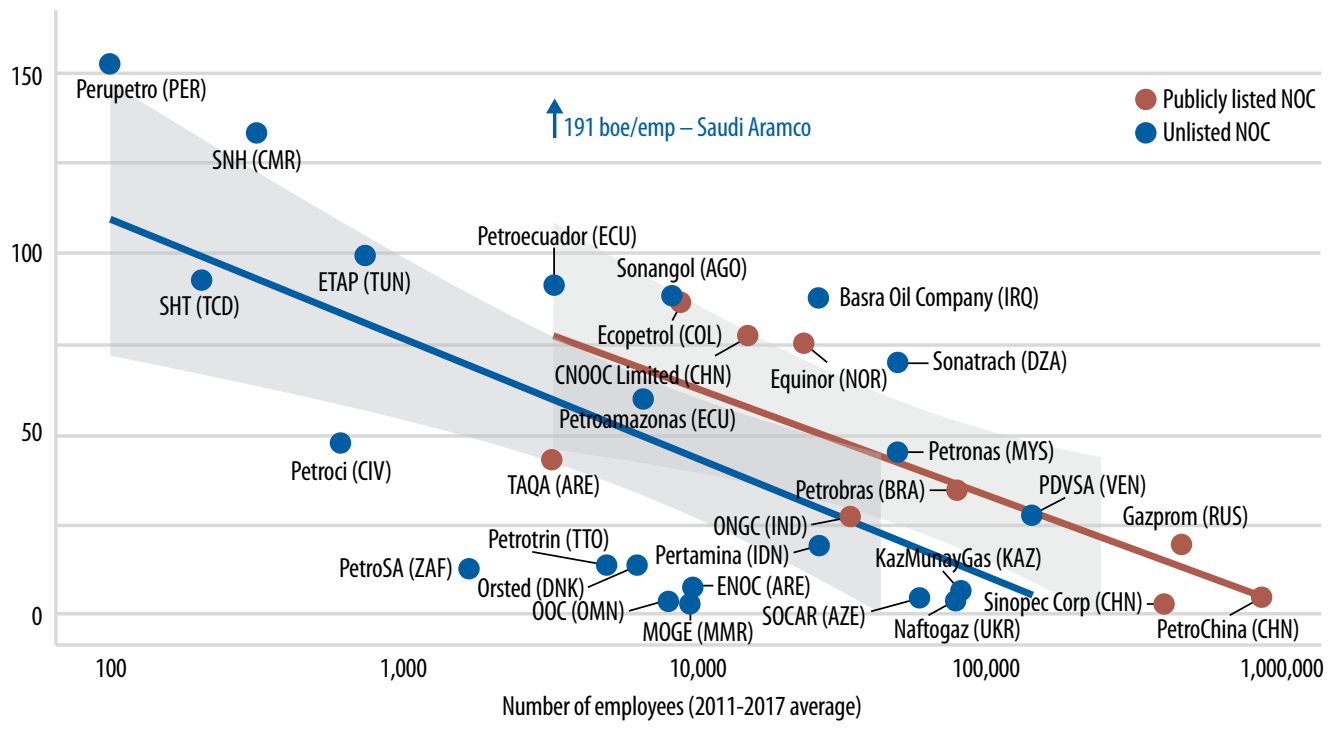

Source: Heller and Mihalyi (2019)

Note: For display purposes and in calculating the trend line, these figures leave out Saudi Aramco-the largest oil and gas producer in the world, which registers an outstandingly large production per employee (an average of 191 barrels of oil equivalent per day).

The differences between publicly-listed and unlisted national oil companies are less pronounced when this outlier is included. Data labels in the chart use International Organization for Standardization (ISO) country codes. NOC = national oil company.

NOC-dependent countries grows with the prospect that a global transition away from fossil fuels may lead to a terminal decline in oil and gas prices, which could render many of the assets in which NOCs are investing economically unviable. This makes diversification even more important, lest these countries become "stranded nations" continuing to spend heavily to maintain the sector, without a viable alternative to fossil fuel dependence.

\section{Urgent need of reform}

A number of governments have relied heavily on NOCs for revenues, energy, jobs, and economic development. But many NOCs struggle with commercial inefficiencies and substantial debt accumulation, and energy transition will amplify these challenges. To mitigate the risks and carve out an effective way forward, NOC reform is an urgent priority.

NOCs and their governments should ensure that company strategies outline a sustainable vision for their futures. Such a vision can facilitate clear and effective rules on how much NOCs are allowed to spend and borrow and how much they must transfer to the government treasury.

To ensure that these rules are followed, citizens and governments need better reporting from NOCs. Separating public relations from reality in NOC pronouncements about investments in renewables or boosting commercial efficiency requires consistent reporting on spending, production costs, and revenues.
The IMF could also play a more active role by routinely requiring the disclosure of audited annual accounts for NOCs (and other large state-owned enterprises) as part of its surveillance mandate, given the fiscal risks they often present. It should also provide clearer guidance as to when countries should include NOCs in public accounts, given the multiple roles that many of these companies play.

Finally, like private oil companies, NOCs should start assessing and disclosing how prepared they are for energy transition. This should include an analysis of climate-related risks to their upstream activities and progress made in diversifying and mitigating risks. FD

DAVID MANLEY is a senior economic analyst at the Natural Resource Governance Institute (NRGI), DAVID MIHALYI is a senior economic analyst at NRGI and a visiting fellow at the Central European University's School of Public Policy, and PATRICK R. P. HELLER is an advisor NRGI and a senior visiting fellow at the Center on Law, Energy and Environment at the University of California, Berkeley.

\section{References:}

Heller, Patrick R. P., and David Mihalyi. 2019. Massive and Misunderstood: Data-Driven Insights into National Oil Companies. New York: Natural Resource Governance Institute.

National Resource Governance Institute. 2019. National Oil Company Database. New York. https://www.nationaloilcompanydata.org/.

Victor, Nadejda. 2007. "On Measuring the Performance of National Oil Companies."Working Paper 64, Program on Energy and Sustainable Development, Stanford University, Stanford, CA. 


\section{A Greener Future for Finance}

\section{Green bonds offer lessons for sustainable finance}

\section{Afsaneh Beschloss and Mina Mashayekhi}

GREEN BONDS, LAUNCHED by the World Bank and the European Investment Bank more than a decade ago, blazed a trail for investments that could eventually reach into trillions of dollars in climate-related projects, including renewable energy, energy efficiency, and ecosystem protection and restoration.

Their central, foundational role provides lessons and warnings for the global community as it expands sustainable finance with ever-greater urgency into diverse areas such as complex collateralized loan obligations, loan and local currency guarantees, and subordinated debt.

The initial challenge was far more daunting than developing a bond prototype tied to environmental impact. It was to create a new class of securities that would be credible, replicable, and attractive to institutional investors and environmental organizations alike.

Along those dimensions, the founders of the green bond movement have undoubtedly succeeded. The Climate Bonds Initiative (CBI) stated in its 2018 report that from 2008 to 2018, dozens of institutions and governments issued more than $\$ 521$ billion in green bonds. In the first half of 2019 alone, new certified green bond issues topped $\$ 100$ billion globally, and forecasts for the full year are as high as $\$ 250$ billion, according to Environment + Energy Leader. More than 5,000 green bond issues will have come to market by the end of 2019, estimates CBI. So there is no question that the market for green bonds has proved to be robust, durable, and scalable for a diverse array of market players worldwide.

Kenneth Lay, senior managing director at RockCreek, who as treasurer of the World Bank led the team that developed the first green bonds, says that earmarking bond issue proceeds for specific climate and environment-related projects was a major change "that carried the potential to attract new, impact-oriented investors and boost incentives within the Bank to focus on these key public goods."

He adds: "That potential is being realized, perhaps not as quickly as we all would like, but the progress has been dramatic in the decade since."

Another major challenge, which will continue to bedevil all forms of sustainable finance, has been to ensure that the environmental impact of green bond projects is transparent, verifiable, measurable, and compliant with international standards.

From the start, the World Bank developed a rigorous and transparent model for verifying its green bond issues. Several robust and influential frameworks and protocols have emerged to guide investors and issuers. CBI, launched in 2010, published its Climate Bonds Standard and Certification Scheme the same year. The Loan Market Association notes that the International Capital Markets Association (ICMA), founded in 1969 to help guide the emerging Eurobond market, gradually expanded its scope to include a set of green loan principles in 2014. Both voluntary frameworks gain their authority by assembling teams of top scientists and leaders to develop and promote rigorous standards and by winning the endorsement of a critical mass of issuers and investors. Despite competing national standards and the absence of strong compliance mechanisms for bond issuance, ICMA and CBI have tailored most green bond issues to clear metrics and ensured that projects deliver relevant benefits.

Of course, compliance with standards such as those of ICMA and CBI must be independently verified. The internal incentives of asset owners are insufficient. Leading firms such as CICERO and Sustainalytics have conducted external reviews of more than 88 percent of the 5,000 bonds labeled as green by CBI. Such labeling means that at least 95 percent of proceeds go to environmental uses and that underresearched and controversial areas are excluded. These reviews, along with advance vetting of environmentally focused issuers, have ensured that the assets backing bonds meeting ICMA and CBI minimum requirements are indeed green-along with the majority of funds invested in the bonds.

\section{Dubious players}

That hasn't stopped dubious players from entering the market. From "clean coal" projects in China to bonds sold by Spanish oil company Repsol, issuers have blurred or obliterated the lines between sustainable and nonsustainable projects. The backlash against such projects has sparked a more robust 
debate about the need for more precise definitions of the types of investments that contribute to sustainability and how much.

Investors who adhere to the ICMA or CBI guidelines can be confident that they are supporting low-emission infrastructure and deep emission reduction-perhaps to a fault. For example, to avoid controversy, certification to the highest CBI standards skirts climate-relevant and investable areas such as nuclear energy and issues such as air travel, which accounts for 2 percent of the global carbon intensity of emissions - and growing. What is more, methodical, sector-by-sector analysis takes time. The agencies have only recently explored frameworks for industries such as cement and steel, which together contribute 15 to 17 percent of global carbon dioxide emissions but are essential to building the infrastructure to shift from "brown to green" and to adapt to climate change, such as through electric-vehicle charging stations and floodwalls in low-lying areas.

The growing scale, complexity, and diversity of green bonds, and the green investments that have followed in their wake, may yet pose the most significant challenge for sustainable finance. The Global Sustainable Investment Alliance estimated that $\$ 30.7$ trillion in institutional assets across the world were invested in sustainable; environmental, social, and governance-focused; or green products in six major markets-the Australia, Canada, Europe, Japan, New Zealand, and the United States - at the beginning of 2018. That is an increase of 34 percent since 2016. "Blue bonds," as defined by the World Bank, fund coastal restoration, marine biodiversity, sustainable fisheries, and pollution control. "Humanitarian bonds" target pandemic disease and migration. Meanwhile, specialized issuers such as the International Finance Facility for Immunisation have emerged. Many organizations tracking green finance also follow the broader set of so-called labeled impact bonds, a combined market with an estimated value of up to $\$ 1.45$ trillion as of 2018 .

Sustainable finance may be experiencing a golden age of innovation. New securities and investment structures are emerging with each passing year. The question is whether such creativity is fostering a market in which risks and rates of return are fully transparent, comparable, and accessible in ways that can be consistently monetized. The risk-return conundrum for those investing in green finance is pervasive and challenging. Should investors accept a lower return on green bonds from a given issuer than on that issuer's "brown" offerings? Should issuers expect lower financing costs-a so-called greenium? Should they accept lower internal rates of return on green private equity or infrastructure investments? Fiduciaries' initial reaction has, in many cases, been "no," but this is changing. A great deal of effort is going into better quantifying long-term risks and returns associated with climate, and the United Nations Sustainable Development Goals, versus short-term profits. Progress is beginning to show.

\section{Sustainable finance may be experiencing a golden age of innovation.}

This type of analysis is most advanced in the green bond market, in part because of its scale and relative transparency. Whereas many other bonds in the broader labeled bond market lack the maturity and size to be studied in depth, the green bond market (while quite small in relation to global markets) offers relatively rich data sets for analysis. Nonetheless, a compelling narrative is beginning to emerge from public and private sector data: in case after case, green bonds fare better than their brown peers in pricing, liquidity, and performance. While a definitive conclusion remains elusive, investors appear to be able to invest in green bonds without hurting portfolio performance, and there is upside potential over time as climate-resilient assets prove to carry lower risks and the potential for better returns.

The implications are clear. Institutional investors must be savvy in seeking to allocate ever-larger sums of capital to green finance. Long-term, sustainable investors and asset owners must insist on rigorous analysis and a high threshold for institutional engagement. They will need seasoned, experienced, and nimble advisors and managers. FD

AFSANEH BESCHLOSS is founder and CEO of RockCreek, a global asset management firm. Previously, she was treasurer and chief investment officer of the World Bank. MINA MASHAYEKHI is senior advisor at RockCreek. Previously, she led high-level negotiations on trade and sustainability at the United Nations Conference on Trade and Development. 


\section{The SDR's Time Has Come}

\section{Rethinking the Special Drawing Right could bolster the IMF's role in the global financial safety net}

\section{José Antonio Ocampo}

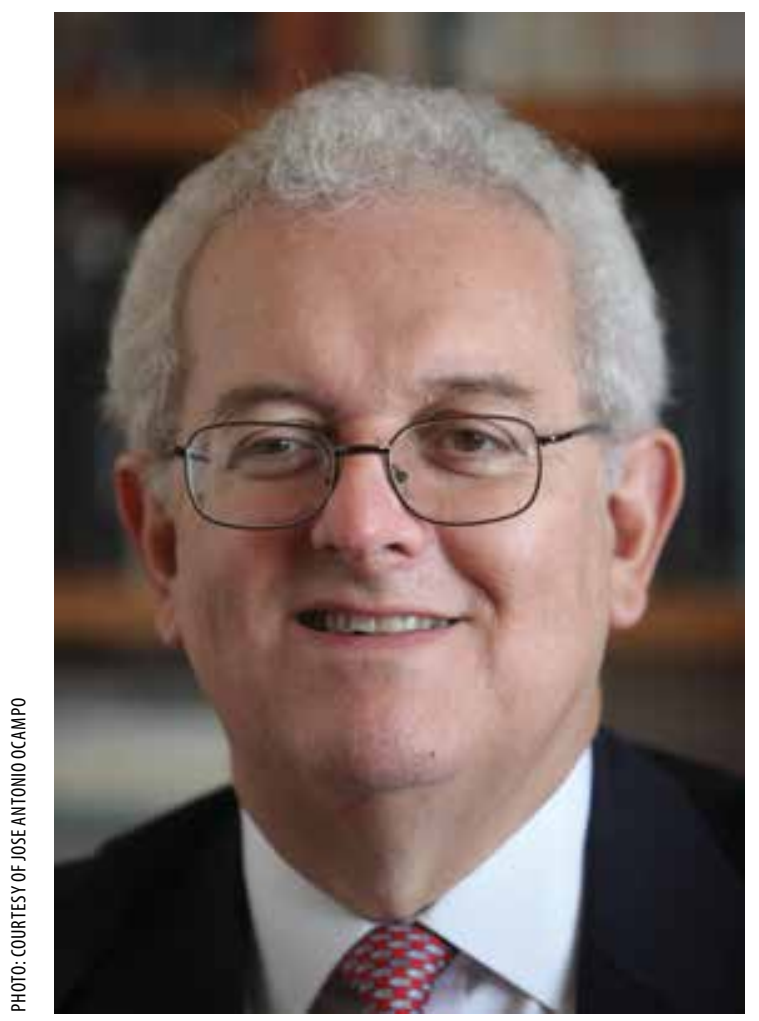

THIS YEAR'S 75TH ANNIVERSARY of the Bretton Woods conference that created the IMF and World Bank coincided with the half-century celebration of the inclusion of the Special Drawing Right (SDR) in the IMF Articles of Agreement.

We also saw in 2019 the spread of crypto-assets and the launch of Facebook's proposal to create Libra, a global digital currency based on blockchain technology. Central banks are actively discussing issuing digital national currencies, and former IMF Managing Director Christine Lagarde raised the possibility of launching a digital version of the SDR.

In this brave new world, is it time to rethink the SDR's role?

The SDR—created 50 years ago to supplement IMF member countries' official reserves-is the only true global money, backed by all IMF members. The IMF's Articles of Agreement envisioned it as "the principal reserve asset in the international monetary system." But the SDR has turned out to be one of the most underutilized instruments of international cooperation. A more active use of this tool would significantly strengthen the IMF's role as the center of the global financial safety net.

\section{Origins of the SDR}

The idea of a global currency goes back to John Maynard Keynes's bancor, the unit of account of his proposed International Clearing Union. There have been three issues of SDRs: the initial one, in 1970-72, of 9.3 billion SDRs; the second, in 1979-81, of 12.1 billion; and a third, in 2009, of 182.7 billion SDRs. The latter included 21.5 billion that had been approved in 1997 but had never gone into effect, as well as a new allocation of SDR 161.2 billion (equivalent to $\$ 250$ billion) as one of the measures to manage the international financial crisis.

Historically, the SDR has represented only a small fraction of global reserves: 8.4 percent of nongold reserves at its peak in 1972 and less than 3 percent in recent years. Only central banks and a few international organizations can hold SDRs. In practice, SDRs are mainly used by central banks from developing countries to pay other IMF members, in addition to serving as the IMF's unit of account.

A basic advantage of the SDR is that it can be deployed during global financial crises as an instrument of international monetary policy, as was done in 2009. But SDRs could also be issued more systematically in a countercyclical way. Various economists have estimated that, as a supplement to other reserve assets, the IMF could issue $\$ 200$ billion- $\$ 300$ billion in SDRs annually.

The major limitation on the use of SDRs is the division between the IMF's general resources and SDR accounts, which limits the use of SDRs to payments among central banks. If the two accounts were consolidated, it would be possible to go one 


\section{A virtual SDR could facilitate the SDR's use in private transactions, creating a global cryptocurrency that could circulate along with cryptocurrencies backed by central banks.}

step further and finance IMF programs with the SDRs that have been allocated, thus enabling global monetary creation to take place in a way similar to that in which central banks create domestic money. This would be the most important reform of the system and would echo the proposals made four decades ago by the eminent IMF economist Jacques Polak. The simplest way would be to treat the SDRs countries hold as "deposits" in the IMF, which the institution could then lend to countries in need.

Such a use of the SDR would require a change in the Articles of Agreement, which created the division between the general resources and SDR accounts. It would, of course, also require all central banks to continue to commit to receiving the SDR as a means of payment, which is what gives it the character of global money.

SDRs would thus complement quota increases and eliminate IMF funding's dependence on "arrangements to borrow" and bilateral credit lines, neither of which are true multilateral instruments.

\section{Multiple benefits}

The more active use of SDRs would have three additional advantages. First, it would spread across all countries the seigniorage generated by issuing a global currency. Second, it would reduce the demand from emerging markets and developing economies for foreign exchange reserves as "selfinsurance." Both advantages would be enhanced if there was an agreement to take into account factors besides quota contributions to increase developing economies' share in SDR allocations. Third, it would make the international monetary system more independent of US monetary policy.

Strengthening the IMF as the center of the global financial safety net should involve reinforcing its precautionary instruments. Robust precautionary facilities would also help overcome any stigma associated with borrowing from the IMF. Beyond those currently in place, these precautionary instruments should include a global swap arrangement, an idea that the IMF staff proposed to the Executive Board in 2017 and the G20 Eminent Persons Group recommended last year. SDRs could be used to finance such a facility.

A number of analysts-Richard Cooper, Barry Eichengreen, and Tommaso Padoa-Schioppa, among others- have suggested that any ambitious reform of the SDR should also embrace the private use of this global currency. This could include using SDRs to denominate private or government bonds or as a unit of account in commercial transactions (for example, in commodity pricing). A virtual SDR could facilitate the SDR's use in private transactions, creating a global cryptocurrency that could circulate along with national or regional cryptocurrencies backed by central banks. This would certainly be preferable to existing crypto-assets, all of which have experienced highly volatile prices, or to Facebook's Libra, which faces monumental regulatory challenges and nearly universal opposition by governments.

Despite the appeal of a "market SDR," though, the major challenge is to reinforce the role of the SDR as a reserve asset, which could be achieved even if SDRs continue to be managed mainly by central banks. It is easy to imagine a variety of intermediate solutions that would allow a partly private use of SDRs, such as permitting financial institutions' deposits in central banks to be held in SDRs (as either reserve requirements or excess reserves).

The anniversaries of the IMF and the SDR, along with the naming of a new IMF Managing Director, provide an excellent chance to think big about the SDR's role in the development of a stronger global financial safety net. The IMF should not pass up this opportunity. FD

JOSÉ ANTONIO OCAMPO is Colombia's former minister of finance and public credit and a professor at Columbia University. Currently a board member of Colombia's central bank, he is the author of Resetting the International Monetary (Non)System. 


\section{Ahead of His Time}

\section{Mathematician and computer science pioneer Alan Turing will appear on UK currency}

\section{Melinda Weir}

ONE MONDAY LAST July, Bank of England Governor Mark Carney strode onto the stage at the Science and Industry Museum in Manchester to reveal the next face of the United Kingdom's $£ 50$ note, one that the bank had earmarked for science.

The honor, he announced, would go to Alan Turing (1912-54)—mathematician, World War II code breaker, and father of computer science.

Turing was a visionary as well as a revolutionary, in Carney's words, and an outstanding mathematician whose work has had a considerable impact on how we live today.

Turing's seminal 1936 paper "On Computable Numbers" imagined the very concept of modern computing. His code-breaking machine is credited with shortening World War II. And his revolutionary postwar work helped create the world's first commercial computers and articulated philosophical and logical foundations for artificial intelligence.

He was, Carney said, "a giant on whose shoulders so many now stand.”

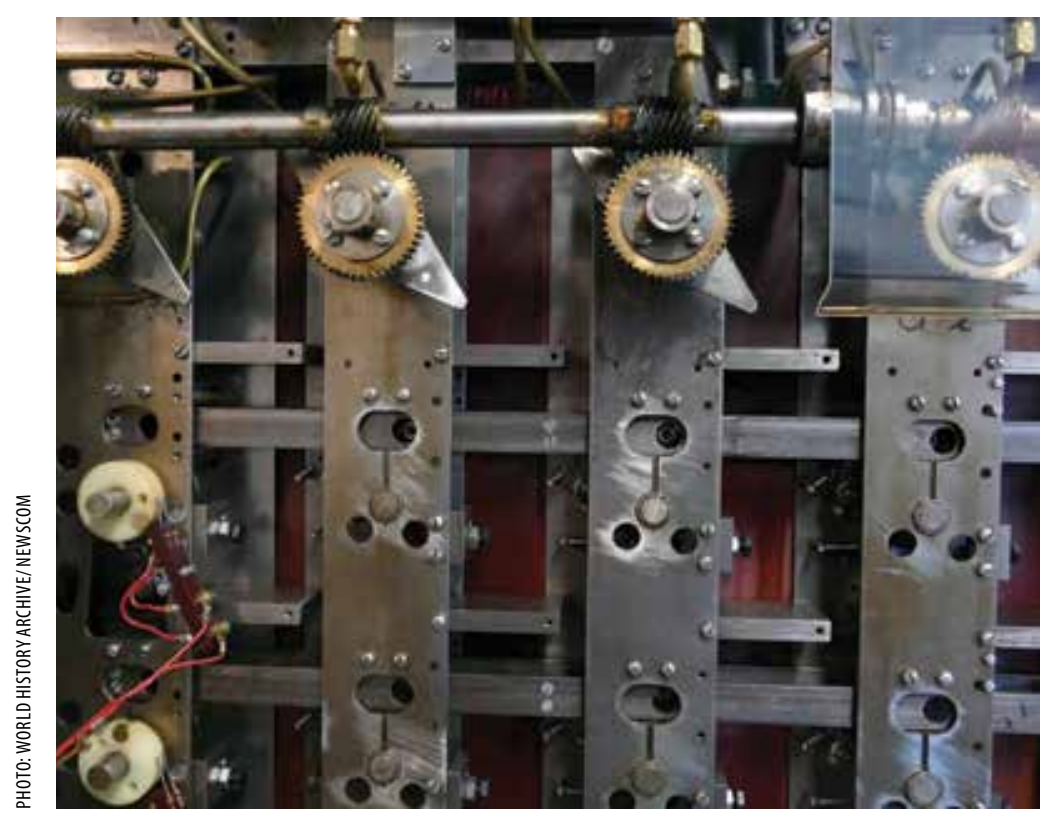

A close-up of a rebuilt Bombe device, an electromechanical codebreaking machine used by British cryptologists in World War Il. Turing was instrumental in the development of the machine, adapted from a Polish design.

\section{Imagining the computer}

Celebrated in books and cinema-the 2014 movie The Imitation Game was based on his biographyTuring is best known by the British public for his wartime efforts, Sarah John, the Bank of England's chief cashier, told $F \& D$. With his colleagues at Bletchley Park, the government's top-secret codebreaking center, Turing developed the code-breaking Bombe machine and made other advances in decryption, which, building on work from Polish mathematicians, led to cracking the German Enigma code. His team's work is widely credited with expediting the war's end, saving millions of lives.

But it is Turing's influence as a profound and inventive thinker of the modern digital age that the new $£ 50$ is celebrating, according to John.

"If you think about where that idea has taken us between 1936 and today," said John, referring to Turing's groundbreaking paper that year, which proposed a computing machine, "and how much computers influence our daily lives - we use them at work, at home, in hospitals, most of us have got a small computer in our pockets that we use on a day-to-day basis - that legacy of starting the computer revolution is really what we're trying to celebrate on this banknote."

Turing was selected for the $£ 50$ after a monthslong "Think Science" campaign by the Bank of England, which elicited nearly a quarter-million nominations from the public, later whittled down by a committee of scientists and central bank officials.

The short list included chemist Rosalind Franklin, instrumental in discovering the structure of DNA; theoretical physicist Stephen Hawking; and Srinivasa Ramanujan, who transformed modern mathematics.

\section{Posthumous apology}

Turing also left another legacy. Turing was a gay man during a time when Victorian-era antigay laws were in place. He was arrested and convicted 


\section{Bank of England}

m-comfig. Symbol Operations m-config.

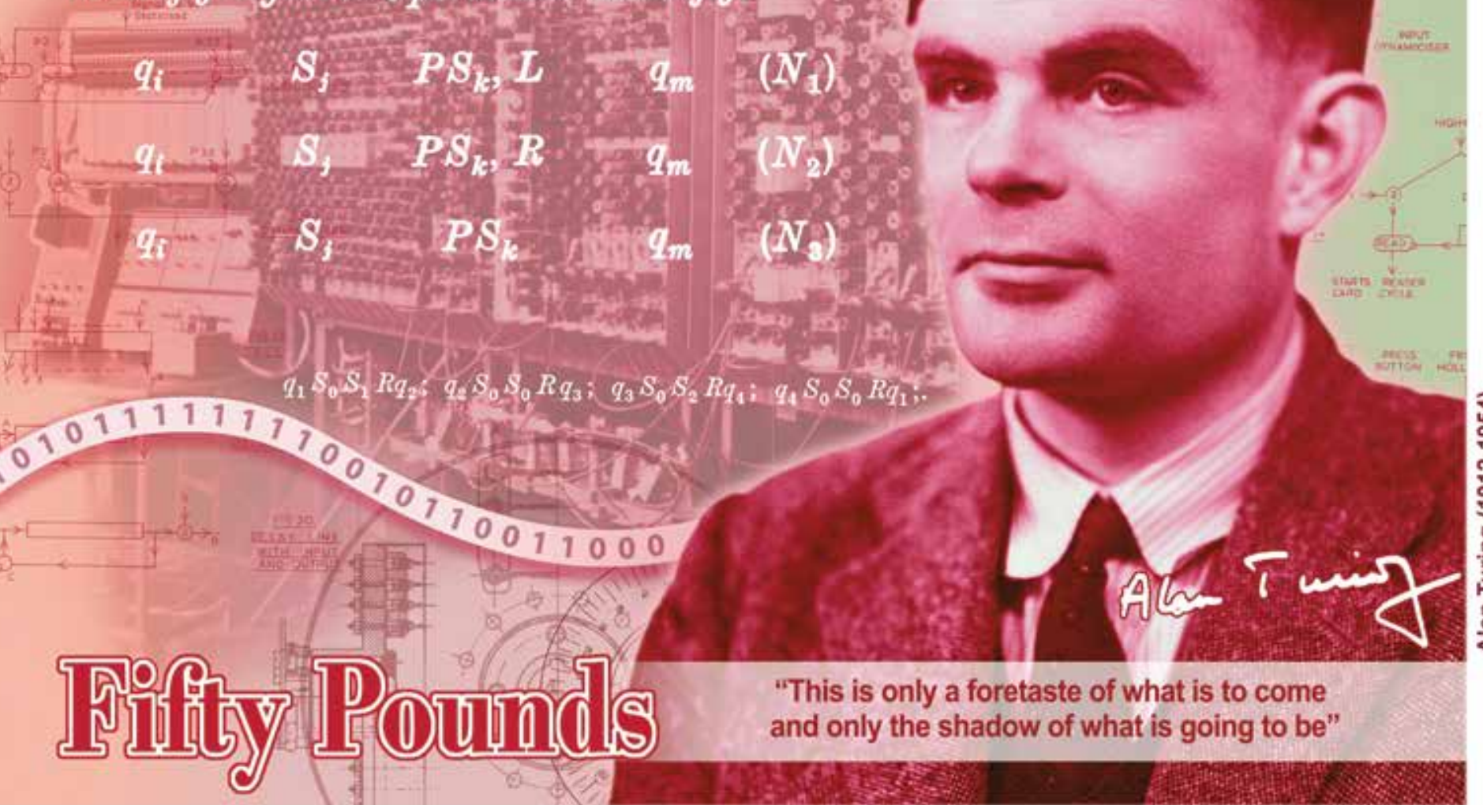

of "gross indecency" for a private relationship and had his government security clearance revoked, effectively putting an end to his career. To avoid prison, he submitted to chemical castration. Turing's death soon after, at the age of 41, was ruled a suicide.

In 2009 the British government issued a posthumous apology for Turing's treatment; he later received a formal royal pardon. And in 2017 legislation known as the "Alan Turing law" was passed, pardoning those convicted under the longrescinded antigay laws of the time.

Public response to the selection of Turing has been positive, according to John. "Turing's work has resonated with people in the sense they understand how important computers are to our everyday lives," John said. But his life story has also resonated and "helped demonstrate that some of the prejudices of the past were really quite unjust and that we've come a very long way, but also highlighted how far we still have to go in society," she added.

A photo of Turing, along with a composite image representing some of his groundbreaking ideas and inventions, will appear on the reverse side of the new $£ 50$ notes, scheduled to be issued in late 2021.
Last redesigned in 2011, the $£ 50$ bill will be printed on polymer for the first time: it's much harder to counterfeit and more resilient and has a lower carbon footprint than paper, according to John. (The $£ 5$ and $£ 10$ notes have already come out on polymer, with the polymer $£ 20$ set to be issued in 2020.)

In the United Kingdom as elsewhere, cash use is quickly being supplanted by various forms of digital payments - a fact that Turing himself might appreciate and could potentially have envisioned. (Just 28 percent of UK transactions were in cash in 2018, down from 40 percent in 2016, according to John.) But cash isn't going anywhere soon, John said. In addition to serving everyday practical purposes for many, physical currency has cultural significance. "People really do care about these banknotes and see them as a symbol of our country."

Turing will join three other famous British figures on current banknotes: Sir Winston Churchill (on the $£ 5$ ), the novelist Jane Austen (£10), and soon, the artist J. M. W. Turner, who replaces the economist Adam Smith on the $£ 20$ note next year. FD

MELINDA WEIR is on the staff of Finance \& Development.
The back of the new $£ 50$ note will feature photos of Turing and an early computer developed using his designs, along with technical drawings and mathematical formulas from his 1936 paper, credited with laying the foundations for computer science. 


\section{Featured Titles from the IMF}

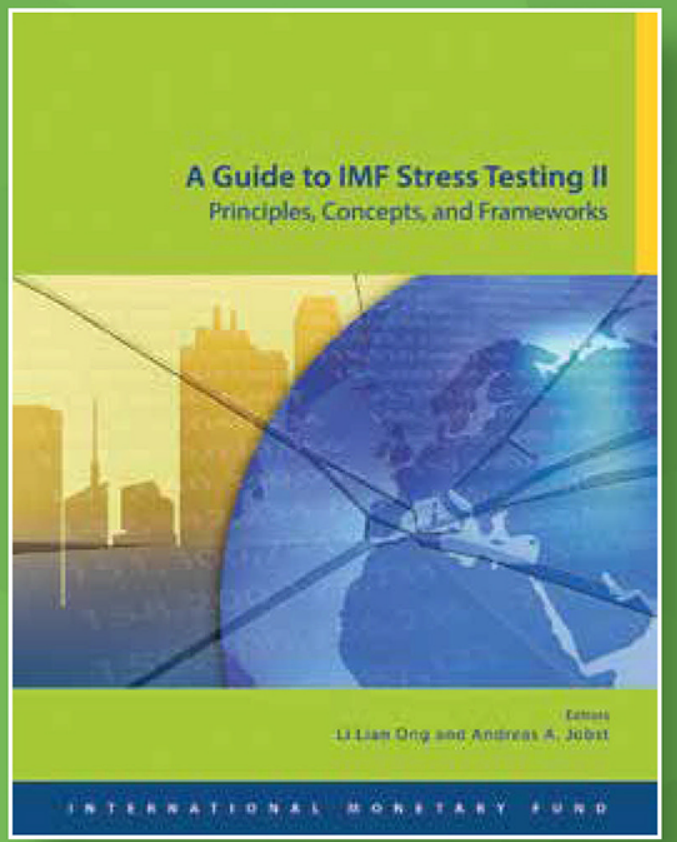

INTERNATIONAL MONETARY FUND

Law \&

Financial Stability

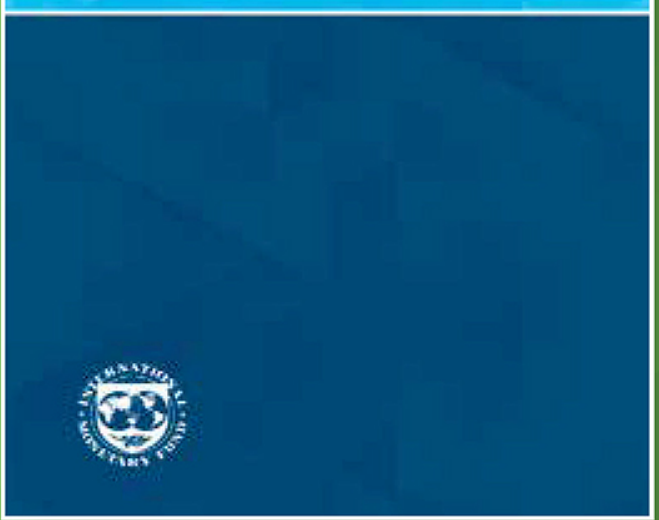

\section{A Guide to IMF} Stress Testing II

\section{rimfe.li/24471}

The new Guide looks at the stresstesting "software" - the best practices, principles, and frameworks needed for the credible and consistent implementation of a stress-testing program.

\section{Law and Financial Stability}

\section{roimfe.li/23553}

This seminar volume presents the legal perspective on implementing the financial regulatory reforms adopted since the global financial crisis. 